\title{
ENVIRONMENTAL ASSESSMENT OF THE ATLAS BIO-ENERGY WASTE WOOD FLUIDIZED BED GASIFICATION POWER PLANT
}


The New York State Energy Research and Development Authority (NYSERDA) is a public benefit corporation created in 1975 by the New York State Legislature. A 13-member board governs NYSERDA.

NYSERDA's primary mission is to carry out a broad program of energy research, development and demonstration projects designed to develop and apply efficient technologies to help ensure that New York has secure and economical future supplies of energy, while protecting environmental values and promoting economic growth.

NYSERDA derives its basic research revenues from an assessment levied on the intrastate sales of New York State's investor-owned electric and gas utilities. Additional research dollars come from limited corporate funds and a voluntary annual contribution by the New York Power Authority.

In its research program, NYSERDA stresses consultation and collaboration with other organizations, including utilities, universities, industries, private engineering and scientific research firms, local governments, and State and Federal agencies. These efforts stretch NYSERDA's limited research funds and ensure the involvement of those who can use the results of the research.

NYSERDA also has responsibility for:

- Managing the 3,300-acre Western New York Nuclear Service Center at West Valley 35 miles south of Buffalo, the site of a former commercial nuclear fuel reprocessing plant and a low-level radioactive waste disposal area. These responsibilities include:

- Participating in the West Valley Demonstration Project, a joint Federal/State effort to solidify the high-level radioactive wastes left over from the reprocessing operation and to clean up the facilities used.

- Maintaining the portion of the site not being used in the Demonstration Project, including the shut-down low-level radioactive waste disposal area.

- Issuing tax-exempt bonds to finance facilities for electric and gas utilities and energy projects for private companies.

- Constructing and operating facilities for disposal of low-level radioactive wastes produced in New York State, once the disposal method and site decisions have been made by the State Low-Level Radioactive Waste Siting Commission and approvals have been issued by State regulatory authorities.

- Managing a 365-acre portion of a Superfund clean-up site in Malta, 20 miles north of Albany. Part of the site was once owned by the Federal government. Portions of it have been used by the Federal government and its contractors since the 1940s for activities that have included rocket engine and fuel testing, weapons testing, and space research.

For more information, contact the Technical Communications Unit, NYSERDA, 2 Empire State Plaza, Suite 1901, Albany, New York 12223-1253, (518) 465-6251.

State of New York

George E. Pataki, Governor
Energy Research and Development Authority

F. William Valentino,

President 


\section{ENVIRONMENTAL ASSESSMENT OF THE ATLAS \\ BIO-ENERGY WASTE WOOD FLUIDIZED BED \\ GASIFICATION POWER PLANT}

Final Report

Prepared for

THE NEW YORK STATE

ENERGY RESEARCH AND DEVELOPMENT AUTHORITY

Project Manager

Jeffrey M. Peterson

Prepared by

ENVIRONMENTAL RISK LIMITED

120 Mountain Avenue

Bloomfield, CT 06002

Project Manager

Michael I. Holzman

3113-ERTER-94

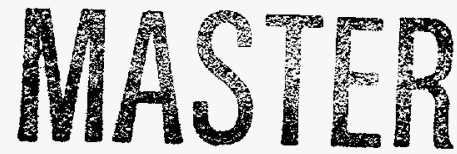

NYSERDA

Report 95-12

August 1995

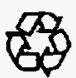




\section{NOTICE}

This report was prepared by Environmental Risk Limited in the course of performing work contracted for and sponsored by the New York State Energy Research and Development Authority (hereafter "NYSERDA"). The opinions expressed in this report do not necessarily reflect those of NYSERDA or the State of New York, and reference to any specific product, service, process, or method does not constitute an implied or expressed recommendation or endorsement of it. Further, NYSERDA, the State of New York, and the contractor make no warranties or representations, expressed or implied, as to the fitness for particular purpose or merchantability of any product, apparatus, or service, or the usefulness, completeness, or accuracy of any processes, methods, or other information contained, described, disclosed, or referred to in this report. NYSERDA, the State of New York, and the contractor make no representation that the use of any product, apparatus, process, method, or other information will not infringe privately owned rights and will assume no liability for any loss, injury, or damage resulting from, or occurring in connection with, the use of information contained, described, disclosed, or referred to in this report. 


\section{DISCLAIMER}

Portions of this document may be illegible in electronic image products. Images are produced from the best available original document. 


\section{ABSTRACT}

The Atlas Bio-Energy Corporation is proposing to develop and operate a 3 MW power plant in Brooklyn, New York that will produce electricity by gasification of waste wood and combustion of the produced lowBtu gas in a conventional package steam boiler coupled to a steam-electric generator. The objectives of this project were to assist Atlas in addressing the environmental permit requirements for the proposed power plant and to evaluate the environmental and economic impacts of the project compared to more conventional small power plants. The project's goal was to help promote the commercialization of biomass gasification as an environmentally acceptable and economically attractive alternative to conventional wood combustion.

The specific components of this research included:

- Development of a permitting strategy plan;

- Characterization of New York City waste wood;

- Characterization of fluidized bed gasifier/boiler emissions;

- Performance of an environmental impact analysis;

- Preparation of an economic evaluation; and

- Discussion of operational and maintenance concerns.

The project is being performed in two phases. Phase I, which is the subject of this report, involves the environmental permitting and environmental/economic assessment of the project. Pending NYSERDA participation, Phase II will include development and implementation of a demonstration program to evaluate the environmental and economic impacts of the full-scale gasification project.

\section{KEY WORDS}

Biomass/wood gasification

Environmental impacts

Economic evaluation

Wood fuel characterization 



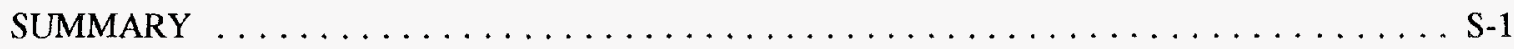

ENVIRONMENTAL PERMIT REQUIREMENTS $\ldots \ldots \ldots \ldots \ldots \ldots \ldots \ldots \ldots$ S-2

WOOD FUEL CHARACTERIZATION $\ldots \ldots \ldots \ldots \ldots \ldots \ldots \ldots \ldots \ldots$. $\ldots \ldots$

EMISSIONS CHARACTERIZATION $\ldots \ldots \ldots \ldots \ldots \ldots \ldots \ldots \ldots \ldots \ldots \ldots \ldots \ldots \ldots$

PRELIMINARY ENVIRONMENTAL IMPACT ANALYSIS $\ldots \ldots \ldots \ldots \ldots \ldots \ldots$ S-5

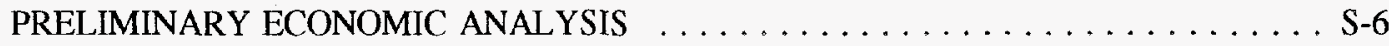

OPERATING/TECHNOLOGY LIMITATIONS $\ldots \ldots \ldots \ldots \ldots \ldots \ldots \ldots \ldots$ S-7

1 ATLAS BIO-ENERGY PLANT DESCRIPTION $\ldots \ldots \ldots \ldots \ldots \ldots \ldots \ldots \ldots \ldots \ldots$

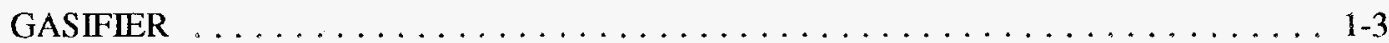

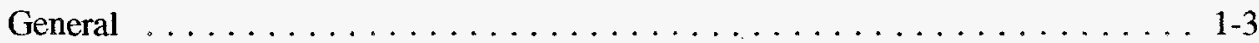

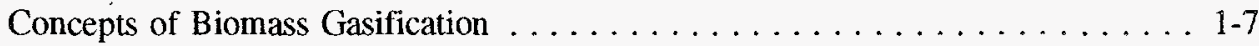

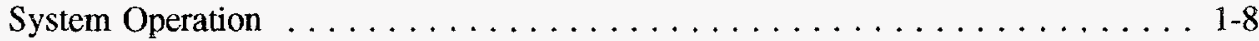

BOILER . . . . . . . . . . . . . . . . . . . . . . . 1-9

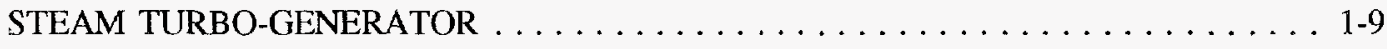

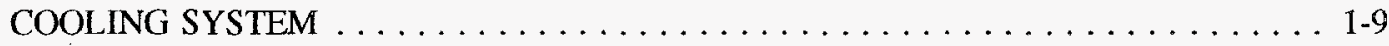

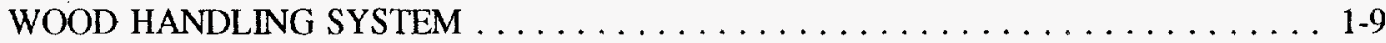

ELECTRICAL SYSTEM . . . . . . . . . . . . . . . . . . . 1-9

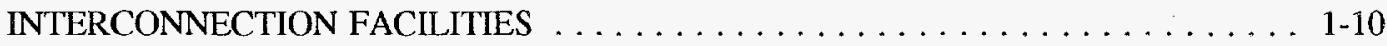

WOOD FUEL DESCRIPTION $\ldots \ldots \ldots \ldots \ldots \ldots \ldots \ldots \ldots \ldots \ldots \ldots$ 1-10

2 ENVIRONMENTAL PERMIT REQUIREMENTS $\ldots \ldots \ldots \ldots \ldots \ldots \ldots \ldots \ldots .2-1$

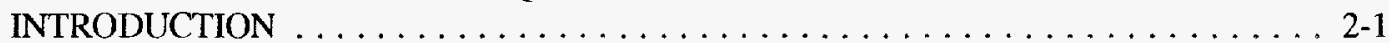

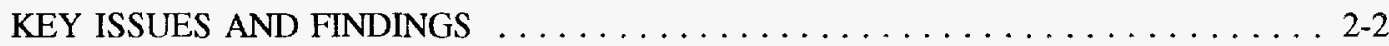

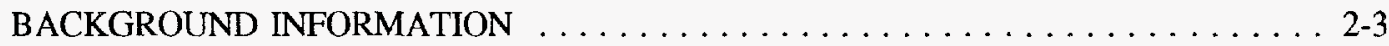

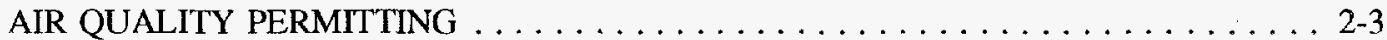

Non-attainment New Source Review . . . . . . . . . . . . . 2-5

New Source Performance Standards . . . . . . . . . . . . . . . 2-6

$\S 60.42 \mathrm{~b}$ Standard for Sulfur Dioxide $\ldots \ldots \ldots \ldots \ldots \ldots \ldots \ldots \ldots \ldots \ldots$

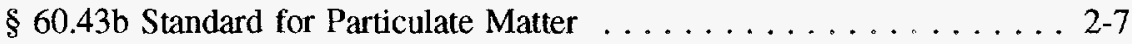

$\S 60.44 \mathrm{~b}$ Standard for Nitrogen Oxides $\ldots \ldots \ldots \ldots \ldots \ldots \ldots \ldots . \ldots \ldots$

Prevention of Significant Deterioration (PSD) Review . . . . . . . . . . . 2-7

Fuel Composition and Use - Sulfur Limitations . . . . . . . . . . . . . 2-8

Wood Source Considerations . . . . . . . . . . . . . . . . . . . . 2-8

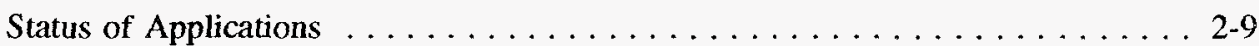

WATER AND WASTEWATER PERMITTING $\ldots \ldots \ldots \ldots \ldots \ldots \ldots \ldots \ldots$. . . . . . . .

NYCDEP Industrial Wastes Control Section Approval . . . . . . . . . . . . 2-9

Site Connection Approval . . . . . . . . . . . . . . . . . 2-11

Local Water Supply ........................... 2-13

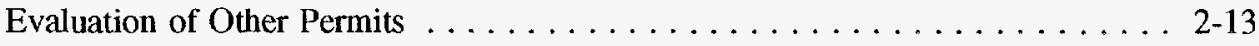

SOLID WASTE MANAGEMENT FACILITIES PERMITTING $\ldots \ldots \ldots \ldots \ldots \ldots 2-17$

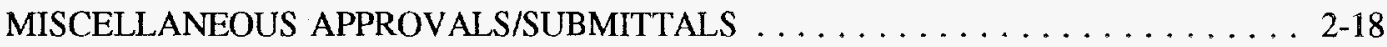

Environmental Assessment Forms . . . . . . . . . . . . . . . . 2-18

State Environmental Quality Review Process $\ldots \ldots \ldots \ldots \ldots \ldots \ldots . \ldots . \ldots .18$

SPCC Plan . . . . . . . . . . . . . . . . . . . . . 2-19

Local Approvals . . . . . . . . . . . . . . . . . . . . . . . . 2-19

CONCLUSIONS .............................. 2-20 


\section{TABLE OF CONTENTS (CONTINUED)}

$\underline{\text { Section }}$

$\underline{\text { Page }}$

WOOD FUEL CHARACTERIZATION $\ldots \ldots \ldots \ldots \ldots \ldots \ldots \ldots \ldots \ldots \ldots$ 3-1

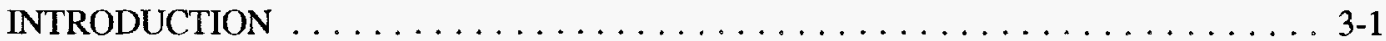

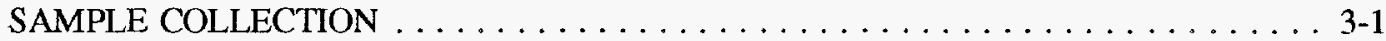

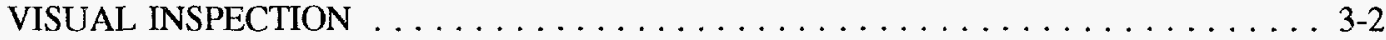

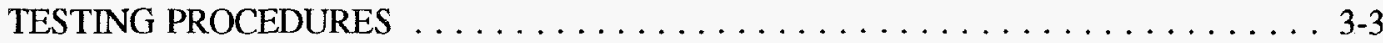

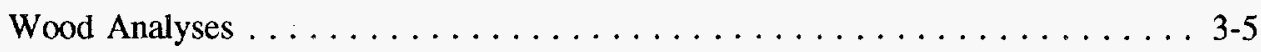

Trace Elemental Analysis . . . . . . . . . . . . . . . 3-5

Ulimate/Proximate . . . . . . . . . . . . . . . . 3-5

Chlorine . . . . . . . . . . . . . . . . . . . . 3-6

Laboratory Ash Fusion Temperature . . . . . . . . . . . . . 3-6

Ash Analyses . . . . . . . . . . . . . . . . . . . . . . . . 3-6

Mineral ...................... 3-6

Trace Elemental Analysis . . . . . . . . . . . . . . . .

Toxic Characteristic Leaching Procedure (TCLP) . . . . . . . . . . 3-7

PILOT-SCALE COMBUSTION TESTS $\ldots \ldots \ldots \ldots \ldots \ldots \ldots \ldots \ldots \ldots \ldots \ldots . . \ldots \ldots$

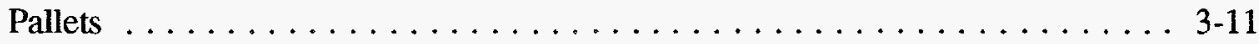

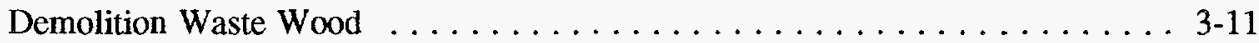

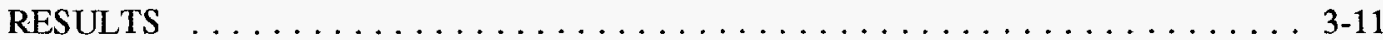

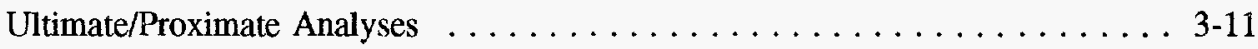

Laboratory Ash Fusion Temperatures . . . . . . . . . . . . . . . 3-11

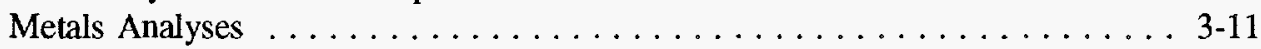

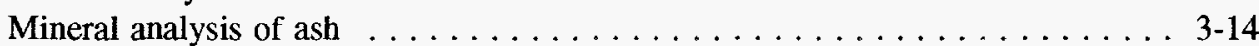

Total Elemental Analysis in Ash Samples . . . . . . . . . . . . . . . . 3-14

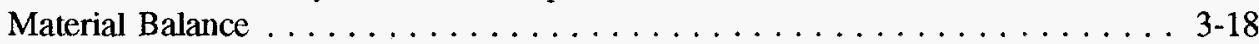

Comparison With Other Wood Data $\ldots \ldots \ldots \ldots \ldots \ldots \ldots \ldots \ldots \ldots \ldots \ldots .24$

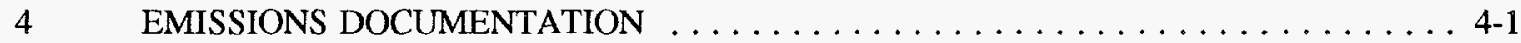

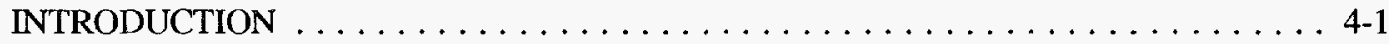

EMISSIONS DATA FROM GASIFIER/BOILERS $\ldots \ldots \ldots \ldots \ldots \ldots \ldots \ldots \ldots$ 4-1

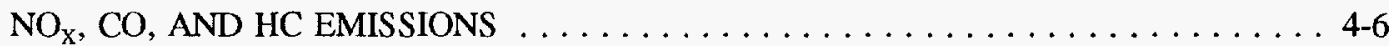

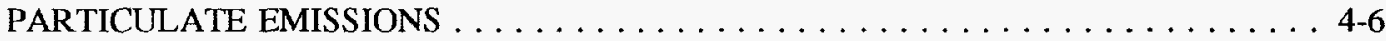

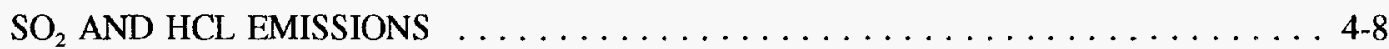

NONCRITERIA POLLUTANT EMISSIONS $\ldots \ldots \ldots \ldots \ldots \ldots \ldots \ldots \ldots \ldots$ 4-10

EMISSIONS SUMMARY $\ldots \ldots \ldots \ldots \ldots \ldots \ldots \ldots \ldots \ldots \ldots \ldots \ldots \ldots$

5 PRELIMINARY ENVIRONMENTAL IMPACT ANALYSIS $\ldots \ldots \ldots \ldots \ldots \ldots \ldots$ 5-1

INTRODUCTION . . . . . . . . . . . . . . . . . . . . . . 5-1

CHAR CHARACTERISTICS AND SOLID WASTE DISPOSAL IMPACTS $\ldots \ldots \ldots \ldots$ 5-1

COMPARING EMISSIONS TO CONVENTIONAL POWER PLANTS $\ldots \ldots \ldots \ldots \ldots 5-2$

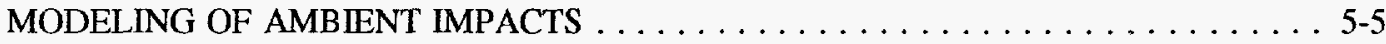

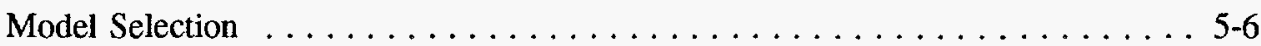

Urban/Rural Determination . . . . . . . . . . . . . . . . . 5-6

Receptors ........................

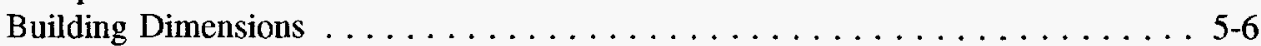

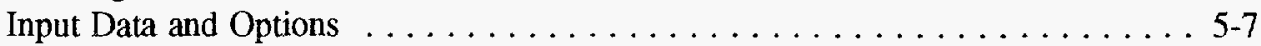

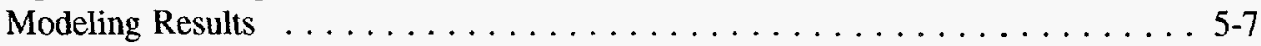


TABLE OF CONTENTS (CONTINUED)

$\underline{\text { Section }}$

$\underline{\text { Page }}$

6

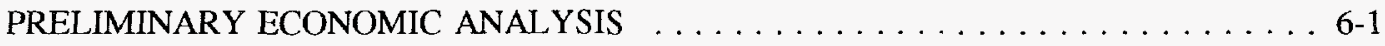

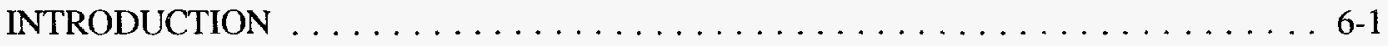

MECHANICS OF THE SPREADSHEET OPERATION $\ldots \ldots \ldots \ldots \ldots \ldots \ldots \ldots$ 6-1

INPUTS TO THE MODEL - GENERAL USER $\ldots \ldots \ldots \ldots \ldots \ldots \ldots \ldots \ldots \ldots .6 .1$

INPUTS TO THE MODEL - THIS STUDY $\ldots \ldots \ldots \ldots \ldots \ldots \ldots \ldots \ldots \ldots \ldots \ldots .6 \ldots$

Personnel ..........................

Taxes . . . . . . . . . . . . . . . . . . . . . . . . . 6-2

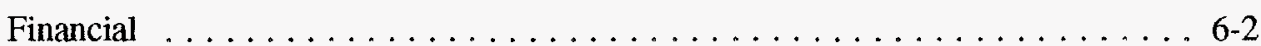

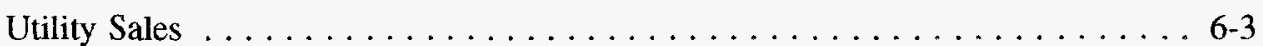

Retail Power Offset . . . . . . . . . . . . . . . . . . 6 6-3

Laboratory Costs . . . . . . . . . . . . . . . . . . .

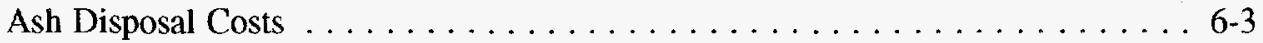

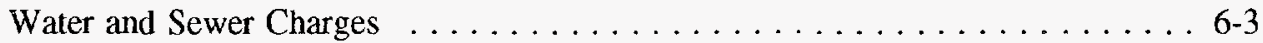

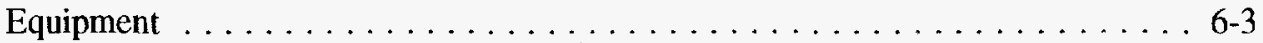

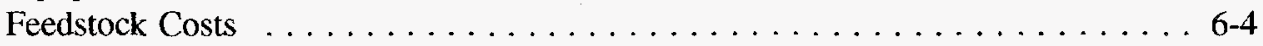

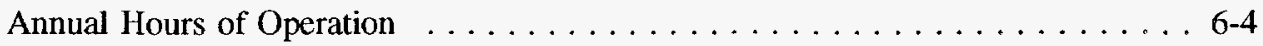

RESULTS OF THE ECONOMIC MODEL $\ldots \ldots \ldots \ldots \ldots \ldots \ldots \ldots \ldots \ldots$

7 OPERATING/TECHNOLOGY LIMITATIONS $\ldots \ldots \ldots \ldots \ldots \ldots \ldots \ldots \ldots \ldots$

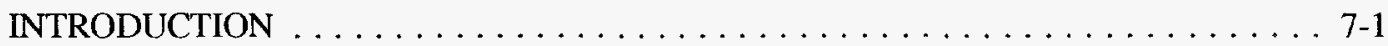

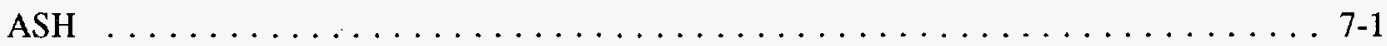

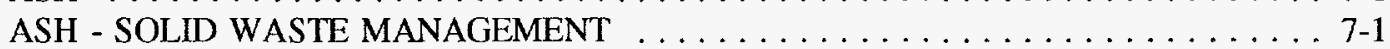

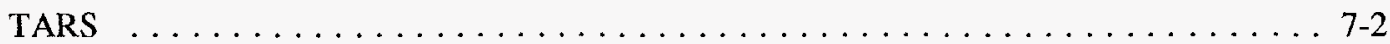

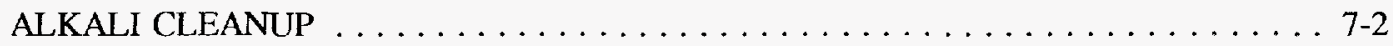

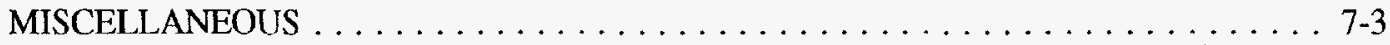

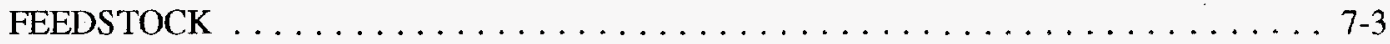

PRODUCER GAS COMPATIBILITY WITH CONVENTIONAL COMBUSTION

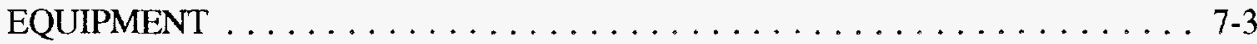

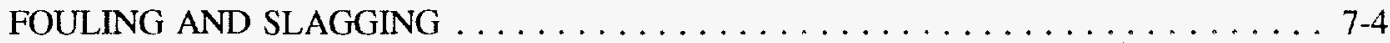

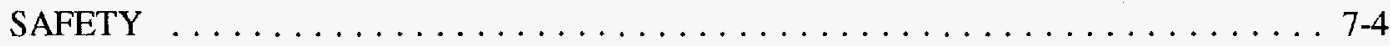

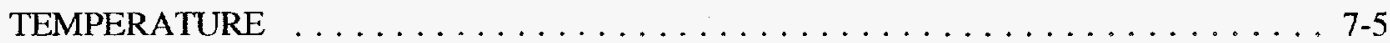

FIGURES

Figure

\section{$\underline{\text { Page }}$}

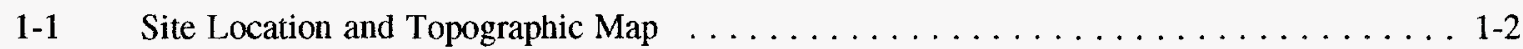

1-2 Material Balance Flow Sheet, High Moisture Fuel Case $\ldots \ldots \ldots \ldots \ldots \ldots \ldots \ldots \ldots \ldots$

1-3 Material Balance Flow Sheet, Base Case . . . . . . . . . . . . . . . 1-5

1-4 Material Balance Flow Sheet, Low Moisture Fuel Case $\ldots \ldots \ldots \ldots \ldots \ldots \ldots \ldots$. $\ldots \ldots$

3-1 Waste Wood Fuel Characterization Study . . . . . . . . . . . . . . . . 3-4

3-2 EPA Method 5 Particulate Matter Sample Train $\ldots \ldots \ldots \ldots \ldots \ldots \ldots \ldots \ldots \ldots$ 
TABLES

2-1 Atlas Bio-Energy Proposed Emissions Rates . . . . . . . . . . . . . . . . . 2-4

3-1 Stack Test Results, Pilot-Scale Combuster . . . . . . . . . . . . . . . . . . . . . 3-10

3-2 Ultimate/Proximate Analysis of Waste Fuel Samples . . . . . . . . . . . . . 3-12

3-3 Laboratory Ash Fusion Temperatures of Waste Fuel Samples . . . . . . . . . . . . . . . 3-13

3-4 Clean Wood Incremental Analyses, Metals Concentrations in Waste Wood . . . . . . . 3-15

3-5 Construction/Demolition Wood Incremental Analyses, Metals Concentrations in Waste Wood . . . . . . . . . . . . . . . . . . . . . . . . . 3-15

3-6 Summary Data of Clean Wood Analyses, Metals Concentrations in Waste Wood ... . . 3-16

3-7 Summary Data of Construction/Demolition Wood Analyses, Metals Concentrations in Waste Wood . . . . . . . . . . . . . . . . . . . . . . . . .

3-8 Minerals in Ash Analysis of Ash Generated in Pilot-Scale Combustion Facility . . . . . 3-17

3-9 Total Elemental Analysis in Clean Wood Waste Fuel and Ash Samples Generated in PilotScale Combustion Facility $\ldots \ldots \ldots \ldots \ldots \ldots \ldots \ldots \ldots \ldots \ldots \ldots . \ldots \ldots \ldots$ 3-19

3-10 Total Elemental Analysis in Construction/Demolition Wood Waste Fuel and Ash Samples Generated in Pilot-Scale Combustion Facility . . . . . . . . . . . . . . . . . 3-19

3-11 TCLP Analysis of Ash Generated in Pilot-Scale Combustion Facility . . . . . . . . . . 3-20

3-12 Mass Balance of Clean Wood Waste Test Burn, November $1994 \ldots \ldots$. . . . . . . . . 3-22

3-13 Mass Balance of Demolition Wood Test Burn, November $1994 \ldots \ldots \ldots \ldots \ldots$. . . . . . . . .

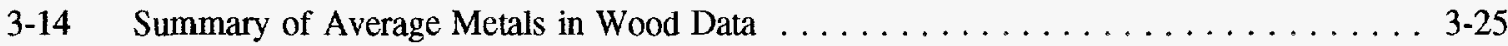

3-15 Summary of Average Metals in Ash Data . . . . . . . . . . . . . . . 3-25

4-1 Catalyst North Powder, Oregon - Emissions and Plant Data Summary . . . . . . . . 4-3

4-2 Emission Test Results, Biomass Woodchips, State Central Heating Plant . . . . . . . . 4-4

4-3 Highgrove Wood Gas Emissions Summary - Flare and Boiler . . . . . . . . . . . 4-5

4-4 COEN Company, Inc. Low- $\mathrm{NO}_{\mathrm{x}}$ Burner Expected Emissions for $\mathrm{NO}_{x}, \mathrm{CO}$ and $\mathrm{HC} \ldots . .4-7$

4-5 Particulate Emissions from Fluidized Bed Combustors with Baghouses . . . . . . . . . 4-9

4-6 PAH Test Results On Highgrove \#4 While Firing Natural Gas With Woodgas, March 4, 1986 . . . . . . . . . . . . . . . . . . . . . . . . . . . . . 4-11

4-7 PAH Emissions From Flare, November 18, $1987 \ldots \ldots \ldots \ldots \ldots \ldots \ldots \ldots \ldots$. . . . . . . . . . . .

4-8 Metal to Vapor Conversion vs. Temperature, Comparing Swiss Federal Institute of Technology Study on Pyrolysis to Known Vapor Pressures of Pure Elements . . . . . . . 4-14

4-9 Vapor Pressures of Potential Metals in Waste Wood at Various Gasification Temperatures .......................... 4 15

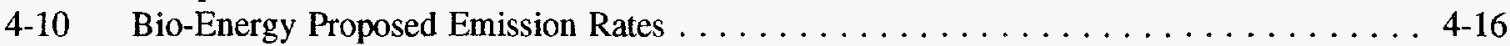

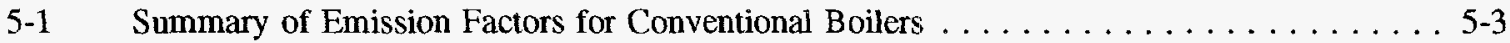

5-2 Comparison of Gasifier/Boiler Emissions with Conventional Boiler Emissions . . . . . . . 5-4

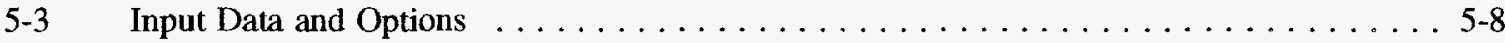

5-4 Summary of Air Quality Impact Analysis Results $\ldots \ldots \ldots \ldots \ldots \ldots \ldots \ldots \ldots$

APPENDIX A Economic Calculations 


\section{SUMMARY}

The Atlas Bio-Energy Corporation (Atlas) is proposing to develop and operate an approximate $3 \mathrm{MW}$ power plant in Brooklyn, New York that will produce electricity through the gasification of waste wood. Processed waste wood from sources in the New York City metropolitan area will be gasified in a fluidized bed gasifier manufactured by Energy Products, Inc. (EPI); the produced low-Btu gas will be combusted in a conventional package steam boiler system coupled to a steam-electric generator.

Biomass/wood gasification for energy production has been claimed as an environmentally and economically beneficial alternative to conventional biomass/wood combustion. Some of the advantages attributed to gasification include:

- Ability to use a wide variety of feedstock types;

- Possible method to dispose of more contaminated fuel, such as CCA-treated wood, since metals and other contaminants should remain in char due to lower gasification operating temperature;

- Relatively low cost for small system installations;

- Potential higher energy efficiency;

- Gasification provides a more uniform fuel source (producer gas) for use in reliable conventional power production equipment (e.g., natural gas power plants); and

- Applicability for biomass energy plantations due to potential to handle high ash content feedstock while minimizing slagging problems associated with biomass combustion.

However, further research is needed to evaluate gasification systems relative to environmental impacts, system design, alkali/particulate cleanup, gas compatibility with conventional power generation equipment, and system efficiency. There are also very limited data available to evaluate the environmental impacts and economics in comparison to conventional wood-fired boilers. Only a few sources of data on emissions and char characteristics from various types of wood gasification systems have been located.

The primary goals of this project were to assist Atlas in addressing the environmental permit requirements to construct and operate the proposed fluidized bed waste wood gasification project, and to evaluate the environmental and economic impacts of the project in comparison to more conventional small power plants. This project will help promote the commercialization of biomass gasification as an environmentally acceptable and economically attractive alternative to conventional wood combustion.

The project has two phases. Phase I, which is the subject of this report, involves the environmental permitting and environmental/economic assessment of the project. Pending NYSERDA participation, Phase II will include development and implementation of a demonstration program to evaluate the environmental and economic impacts of the full-scale gasification project. 


\section{ENVIRONMENTAL PERMIT REQUIREMENTS}

The initial step in the environmental permitting of a project involves the preparation of a permit plan that identifies required permits and key issues and difficulties. This analysis involved a review of the applicable New York State Department of Environmental Conservation (NYSDEC) and New York City Department of Environmental Protection (NYCDEP) rules and regulations for air quality, water quality and solid waste.

\section{Key Issues and Findings}

Based on the results of the environmental permit analysis and the actual permitting process for the Atlas facility, the following key permits and/or approvals are required:

1. Air permit to Construct and Operate a Stationary Combustion Installation - issued by NYSDEC;

2. Permit for a Solid Waste Management Facility - issued by NYSDEC;

3. Industrial Waste Discharge approval and Site Connection permit for discharge of process and domestic wastewaters and storm water from the property - issued by the NYCDEP; and

4. New York City DEP Installation Permit.

The most significant issues affecting the permitting of the facility were:

- Atlas initially proposed to use urban waste wood containing some treated wood components as fuel. However, NYSDEC has made the regulatory interpretation that a facility proposing to use other than clean wood fuel (e.g., proposing to use wood from construction/demolition (C/D) debris and treated wood) will be subject to review as an incinerator in accordance with Part 219 of Title 6 of the New York Code of Rules and Regulations (6NYCRR Part 219). Due to the additional regulatory scrutiny, control requirements, permit review time, and likely public opposition in an urban area, Atlas has decided to revise its acceptable fuel specification to include only clean wood chips. Once the facility is constructed and operating, Atlas will consider modifying its permits to allow use of treated word fuel.

- Location of the facility in an air quality region that has been designated as non-attainment of air quality standards for carbon monoxide (CO) and ozone will result in stringent controls and low emission rates for $\mathrm{CO}$ and ozone precursors (nitrogen oxides and volatile organic compounds) for this relatively small emission source.

- Several factors contributed to significant delays in obtaining permits for this project. Atlas originally made application on January 27, 1992 and submitted revised applications in August 1993 and July 1994. A Notice of Incomplete Application and several requests for additional 
information or clarifications were issued by NYSDEC during this time frame. Initially contributing to this delay were incomplete and inaccurate technical information and analyses provided by Atlas' original consultants. Communication between the regional and Albany NYSDEC staff also appeared to prolong the review process. This experience underscores the necessity for technically complete and consistent permit applications reflecting a thorough understanding of regulatory requirements and issues.

\section{WOOD FUEL CHARACTERIZATION}

The NYSDEC, in its preliminary review of the permit application for the Atlas project, questioned the representativeness of wood fuel characterizations based on data developed from sources outside of the New York City (NYC) region. Therefore, the Contractor identified the major waste wood processing facilities in the NYC area and conducted a sampling and analysis program at one representative facility.

The selected facility is a waste wood processor that receives both clean wood and $C / D$ wood from various sources throughout the city and processes the material into either wood chips or fuel pellets, depending on the grade of the wood. The clean wood received at the facility primarily consists of used pallets and shipping boxes. The C/D wood is received as a mixed waste wood which goes through a manual picking station to remove non-wood, painted wood and treated wood materials.

The Contractor obtained for analysis eight representative one-gallon incremental samples and approximately 150 gallons of mixed sample for each wood type (clean and $C / D$ ). Five of the eight incremental samples were tested for arsenic, lead, chromium, titanium, zinc, and mercury; composites of the samples were analyzed for ultimate/proximate, chlorine, ash fusion temperature, and arsenic, lead, chromium, titanium, zinc, mercury, barium, cadmium, copper, and nickel. The 150-gallon samples were burned in the Contractor's pilot-scale furnace to obtain more representative ash material, which was subsequently analyzed for the same ten metals, Toxic Characteristic Leaching Procedure (metals), and minerals in ash.

Key findings from this study include:

- The relatively low sulfur level in the $C / D$ wood samples could indicate better separation of contaminants such as tar paper and shingles.

- As expected, concentrations of lead, mercury, titanium, and zinc are higher in the C/D wood than in the clean wood, indicating the presence of paint pigments and fungicides in the $\mathrm{C} / \mathrm{D}$ wood. However, arsenic and chromium concentrations in the $\mathrm{C} / \mathrm{D}$ wood were 
only marginally higher than in the clean wood, indicating that pressure treated wood may not have been completely removed from the clean fuel stream.

- Arsenic, barium, and chromium were the only metals detected in the leachate from the TCLP testing of the pilot-plant generated ash. The concentrations in the leachate from the $C / D$ wood ash were well within regulatory limits. However, chromium and arsenic from the clean wood ash were above regulatory levels. Although arsenic and chromium levels in the clean wood were not high, the lower total ash content of the clean wood resulted in higher metals concentrations for these metals than in the $C / D$ wood ash.

- It appears that the clean wood from this study contains generally higher levels of arsenic, chromium, and lead than clean wood from other studies. This indicates that pressure treated wood containing arsenic and chromium, and painted wood containing lead may have been mixed in with the clean wood. The composition of the C/D wood from this study is approximately equal to the average composition of $C / D$ wood from other studies.

\section{EMISSIONS CHARACTERIZATION}

Representative estimates of emissions from the Atlas project were required to prepare the permit application and to assess the potential air quality impacts from the facility. Where possible, the Contractor endeavored to use actual emissions test data from other similar facilities to estimate emissions from the Bio-Energy facility. However, biomass gasification in combination with a packaged steam boiler is still an emerging technology and limited data on emissions from commercial or research facilities were located.

\section{Key Findings}

Key findings pertaining to the emissions characterization include:

- Actual emissions test data most applicable to the proposed project were obtained from compliance test reports for similar wood gasification facilities in Oregon (Catalyst North Powder) ${ }^{1}$ and in California (State Central Heating Plant) ${ }^{2}$. Both of these gasification facilities were supplied by EPI, the same manufacturer of the gasifier for the proposed Bio-Energy project. Due to differences in design and plant configuration, emissions data from other wood gasification plants were not representative enough to characterize emissions from the Atlas project.

- A review of representative emissions data from similar wood gasification/boiler facilities indicates $\mathrm{NO}_{\mathrm{x}}, \mathrm{CO}$ and $\mathrm{HC}$ emissions vary significantly and are more likely a function of the burner design than the gasifier design. Therefore, the approach to estimating emissions from the proposed project relied more on expected burner manufacturer emission rates than the emissions data from existing facilities.

- The proposed project is located in a non-attainment area for carbon monoxide $(\mathrm{CO})$ and ozone. Therefore, a high efficiency, low- $\mathrm{NO}_{x}$ burner design was required to meet stringent emission rates for $\mathrm{CO}$, nitrogen oxides $\left(\mathrm{NO}_{\mathrm{x}}\right)$ and hydrocarbons $(\mathrm{HC})$. The emission guarantees from the burner manufacturer are $0.20 \mathrm{lb} / \mathrm{MMBTU}, 0.05 \mathrm{lb} / \mathrm{MMBTU}$, and $0.015 \mathrm{lb} / \mathrm{MMBTU}$ for $\mathrm{CO}, \mathrm{NO}_{\mathrm{x}}$, and $\mathrm{HC}$, respectively. 
- None of the other wood gasification/boiler plants identified in the data search had high efficiency particulate control devices. They used either wet scrubbers and/or mechanical cyclones. Since the proposed Atlas project was required to meet Best Available Control Technology (BACT), a baghouse was selected with a guaranteed particulate emission rate of $0.04 \mathrm{lb} / \mathrm{MMBTU}$.

- Sulfur dioxide $\left(\mathrm{SO}_{2}\right)$ is emitied in low quantities from typical wood-fired boilers due to low levels of sulfur in the wood fuel. Typically, much less $\mathrm{SO}_{2}$ is formed than is predicted from mass balance calculations. The $\mathrm{SO}_{2}$ reacts with the natural alkalinity in the wood ash to produce calcium sulfites and sulfates. The same mechanism is believed to exist with wood gasification and this is supported from existing $\mathrm{SO}_{2}$ test data on operating systems. The test data indicate an $\mathrm{SO}_{2}$ emission factor of less than $0.02 \mathrm{lb} / \mathrm{MMBTU}$ for clean wood gasification, which is consistent with $\mathrm{SO}_{2}$ emissions from clean wood combustion. A conservative $0.1 \mathrm{lb} / \mathrm{MMBTU}$ level was selected for permitting purposes.

- The only data found on non-criteria pollutant emissions for a wood gasification boiler were for polynuclear aromatic hydrocarbons (PAH). The PAH emissions from the test program were in the same range as those from wood combustion.

- A wood gasifier is theoretically expected to have lower metals and organic emissions than conventional wood combustion. The lower operating temperature of the gasifier should result in less volatilization of metals and the gas burner in the boiler should efficiently oxidize the volatile organics formed in the gasifier.

\section{PRELIMINARY ENVIRONMENTAL IMPACT ANALYSIS}

Environmental impacts associated with conventional wood combustion involve air pollutant emissions and ash disposal. This part of the study evaluated the environmental impacts of the proposed biomass gasification power plant compared to impacts representative of more conventional combustion technology for small power plants, e.g., wood combustion, distillate oil combustion, and natural gas combustion. Key findings include:

- The New York State Environmental Quality Review (SEQR) process determined that the ".. project is an unlisted action and will not have a significant effect on the environment". A negative declaration was made and an environmental impact statement was not required for the project.

- The char from wood gasification consists primarily of carbon and minerals from wood and sand used as the fluidization media in the gasifier. Metals from wood fuel will also tend to be concentrated in the char.

- In theory, due to the lower operating temperatures of a fluidized bed gasifier compared to a wood combustor, metals with relatively low vapor pressures would have less of a tendency to volatilize and partition to the particulate in the flue gas as they do in combustion systems. Therefore, there are theoretical environmental benefits to gasification of a C/D waste wood stream in comparison to combustion in terms of lower metals emissions. However, there were no data to prove this theory or to adequately 
represent the characteristics of waste char to definitively assess the solid waste disposal impacts.

- Managing of the char will require on-going testing in accordance with EPA's Toxic Characteristic Leaching Procedure (TCLP) to determine if it meets current definitions of non-hazardous waste. The char will require disposal in a landfill.

- Compared to a similarly sized conventional wood combustion boiler installed as a new source in Brooklyn, NY, the wood gasification boiler is expected to result in lower emissions of $\mathrm{NO}_{\mathrm{x}}$ and $\mathrm{CO}$, and comparable emissions of $\mathrm{PM}, \mathrm{SO}_{2}$, and $\mathrm{HC}$.

- Compared to conventional distillate oil combustion boilers, the wood gasifier will have higher PM, CO and hydrocarbon emissions. Depending on the sulfur content of the wood fuel, $\mathrm{SO}_{2}$ emissions could be much lower, but in no case will they be higher than the level of $\mathrm{SO}_{2}$ emissions from the combustion of 0.1 percent distillate fuel oil. $\mathrm{NO}_{\mathrm{x}}$ emissions from the wood gasifier system will be about one-third of the emissions from an equivalently sized distillate oil boiler with a low $-\mathrm{NO}_{\mathbf{x}}$ burner.

- Compared to conventional natural gas fired boilers, the wood gasifier will have higher $\mathrm{PM}, \mathrm{SO}_{2}, \mathrm{CO}$, and $\mathrm{HC}$ emissions. $\mathrm{NO}_{x}$ emissions from the gasification boiler will be slightly lower or comparable to those from a natural gas boiler equipped with a low- $\mathrm{NO}_{\mathrm{x}}$ burner.

- There are insufficient data to compare emissions of non-criteria or hazardous air pollutants from a wood gasification boiler to those from a wood combustion boiler. As previously discussed, a wood gasifier is theoretically expected to have lower metals and organic emissions.

- $\quad$ Based on published metals emissions data from distillate oil combustion, depending on the wood fuel source and composition, wood gasification is expected to result in slightly lower emissions of cadmium, chromium, lead, mercury, and nickel and slightly higher emissions of arsenic and manganese than distillate oil combustion.

- Ambient air quality impacts were evaluated using comparative emission rates for the different combustion technologies derived from published emission factors and running computer dispersion models to estimate maximum ambient impacts for comparison to air quality standards. Predicted impacts will be in direct proportion to the estimated emission rates. From the modeling results, the maximum impacts from each technology alternative are in compliance with the National Ambient Air Quality Standards (NAAQS).

\section{PRELIMINARY ECONOMIC ANALYSIS}

A preliminary economic model was developed to evaluate the economics of a fluidized bed gasification/package steam boiler system and to compare the economics to those of conventional combustion technology for electricity generation. Three equipment configurations were considered:

1. Gasifier + Steam Turbine

2. Stoker Boiler + Steam Turbine 


\section{Gasifier + Combustion Turbine}

Each equipment configuration was evaluated at two output sizes: $3 \mathrm{Mw}$ and $30 \mathrm{Mw}$. The $3 \mathrm{Mw}$ size reflects the scale of the wood gasifier project being developed by Atlas Bio-Energy. The $30 \mathrm{MW}$ size is more typical of a commercial system.

The economic model was constructed as a series of linked Lotus $123^{\mathrm{TM}}$ Version 3.4 spreadsheets with an input section, a total capital investment section, and a cash flow analysis section. The model allows the user to easily vary a number of model inputs to evaluate the effects on the analysis.

Based on input assumptions discussed in Section 6, the analysis of these types of plants demonstrates that if the primary purpose is to generate electrical power using purchased fuel, the gasifier-boiler-steam turbine configuration is unlikely to be profitable. Other more proven technology such as the stoker fired boiler and steam turbine, or the gasifier and combustion turbine combination are more fuel efficient and therefore more profitable as a means of generating electrical power for sale. If the need is for generation of smaller amounts of electrical power used to displace purchased utility power at an existing facility, and if the acceptance of the waste wood fuel can generate revenue from tipping fees, then the gasifier-boiler-steam turbine would become economically attractive.

\section{OPERATING/TECHNOLOGY LIMITATIONS}

Potential operational problems with biomass gasification systems requiring further research were identified from a literature review. Identifying problems is important for developing a comprehensive test plan for the demonstration program (i.e., identification of specific operating characteristics to be monitored). The following operating problems were identified:

- $\quad$ Ash is carried out of the gasifier in the gas stream and de-entrained from the gas stream in the cyclone. If there is insufficient removal, fine char-ash dust can clog the burner and boiler. The ash can also cause erosion in the passes of the heat exchanger.

Tars can cause downstream moving parts to stick. Tars at operating temperatures can be viscous fluids but turn into a hard varnish if the system cools. This is particularly a problem on moving parts such as valves. Tar formation increases as the moisture content of the fuel increases. Careful control and operation of the gasifier is required to minimize tar formation.

- Potassium and sodium compounds naturally present in wood form oxides during gasification that can agglomerate in the fluidized bed and subsequently shut down of operations. The alkali deposits can also collect on walls, ledges and other surfaces and 
fine deposits can foul the superheater and cyclone. For flue gas temperatures from 500 to $600^{\circ} \mathrm{C}$, most of the alkali compounds condense on the particulate and can be controlled through particulate cleanup. There is a balance required though; higher temperatures would decrease the amount of tar formation and subsequent problems with tar.

If chlorine or sulfur are present in the fuels in appreciable amounts, then they will also be part of the deposits that form downstream and can lead to corrosion problems.

Dust, tar and corrosive (carbon dioxide, organic acids, ammonia) components of the gas can also cause wear of mechanical parts downstream.

Fuel quality and consistency has a major influence on the operation of both circulating fluidized bed gasifiers and traditional combustors. Both oversized materials and fines will interfere with steady state operation of the gasifier or combustor beds. The presence of a large amount of fines or debris will require more frequent bed maintenance. A high ash content in the fuel will require more frequent bed blow-down, resulting in more solid waste disposal and an increase in erosion effects throughout the system due to more abrasive fresh sand. A high moisture content of the feed may require using pre-dryers for the wood chips.

For gas turbine applications, the fluctuating caloric value and cleanliness of the gas are important. The producer gas must be cleaned free of particulates and other contaminants such as trace alkali metals.

A wood alkali content greater than $0.4 \mathrm{lb} / \mathrm{MMBTU}$ generally results in fouling and slagging problems in the fluidized bed. Adding limestone or kaolin can reduce the effects by absorbing molten sodium and potassium salts or form compounds with higher melting points.

From a safety standpoint, the gasifier must be leak-tight to prevent emission of carbon monoxide. An additional safety concern with gasifiers is the explosivity of the fuel-rich atmosphere during start-ups and shut-downs. 


\section{Section 1}

\section{ATLAS BIO-ENERGY PLANT DESCRIPTION}

The Atlas Bio-Energy Corporation proposes to construct and operate a Gas Fired Electric Generating Station (the Facility) at 895 Essex Street in Brooklyn, New York. The gas will be generated on-site by the gasification of wood chips in a fluidized bed gasifier. The Facility will be owned and operated by Atlas Bio-Energy Corporation (Atlas).

The property is located in a district zoned M1-1, Light Manufacturing, in the East New York section of Brooklyn. Figure 1-1, a topographic map, locates the site, which is approximately 115 feet south of the southeast corner of Stanley Avenue and Essex Street. The site is rectangular, measuring approximately 16,000 square feet, and is bounded by Atlas Roll-Off Corp. to the north, a vacant industrial property to the south, Sheppard Avenue to the east, and Essex Street to the west. The grade elevation at the site is approximately 15 feet above mean sea level. The area surrounding the site is generally flat.

The main components of the facility will be a fluidized bed gasifier, a package boiler, condensing team turbo-generator, cooling tower, and wood fuel handling facilities. The fluidized bed gasifier will be a Model FBG-100 supplied by JWP Energy Products, Inc. The gasifier will accept a maximum of approximately 20,200 pounds per hour of clean waste wood chips at $35 \%$ moisture. Less wood will be required at lower moisture contents. The gasifier also requires natural gas, which is used to preheat the unit and as a pilot fuel; at most, the gasifier will require 5,000 standard cubic feet of natural gas per hour. The wood gasifier will produce a maximum of approximately 48,170 pounds per hour of a low Btu gas (HHV of 108.1 MMBtu/hr and a LHV of $94.0 \mathrm{MMBtu} / \mathrm{hr}$ ). The produced gas will first pass through a primary cyclone to remove waste char and then will be delivered to the Coen gas burner on the package boiler.

The Coen gas burner (model Low NO $\mathrm{DAF} 39$ ) or equivalent will combust 94 million Btu per hour (LHV) of the wood gas, and will be connected to a " $\mathrm{D}$ "-type package water tube boiler. The boiler will produce approximately 61,000 pounds of steam per hour, which will be processed through a steam turbine and generator to create 3000 kilowatts of electricity for sale to the Consolidated Edison Company. Some of the remaining steam will be used to heat the Atlas building; the rest will be condensed and supplied as water to the boiler feed system. Stack gas emissions from the package boiler will be routed through a secondary cyclone and a Wheelabrator Model \#120 Jet III baghouse or equivalent for particulate control. 


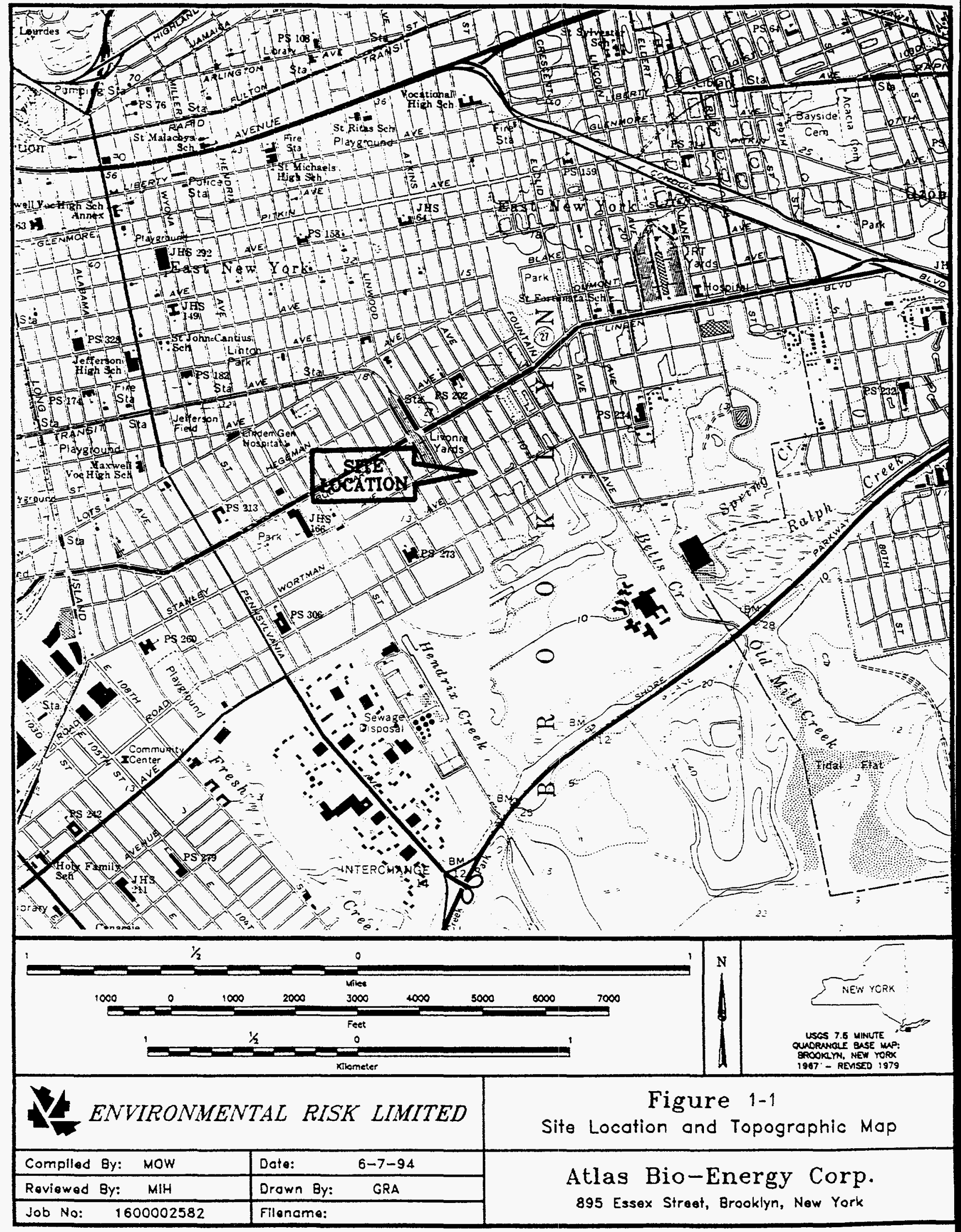


With the gasifier operating at rated capacity, the average daily wood fuel requirement for the Power House will be approximately 196 tons per day assuming a moisture content of $22.45 \%$ or 64,452 tons per year when the plant is operating at a $90 \%$ annual capacity factor. The maximum daily wood fuel requirement will be 242 tons per day assuming the maximum moisture content of 35\%. Atlas Roll-Off Container Service Corporation will supply all of the required processed wood fuel.

During periods when the steam turbine is operating at less than rated capacity, the gasifier will continue to be operated for a boiler load of 61,000 pounds of steam per hour. Steam produced in excess of that required by the steam turbine will be condensed in the surface condenser. This mode of operation will permit the plant to be operated at constant capacity to maintain a steady rate of wood fuel consumption.

Figures 1-2 through 1-4 present complete material balances for the facility based on three different wood fuel moisture conditions. The expected range of fuel moisture contents is 10 to 35 percent; annual average is expected to be approximately 22.5 percent.

Following is a more detailed description of major facility equipment and operating principles of biomass gas generation.

\section{GASIFIER}

\section{General}

The gasification system consists of a Model FBG-100 Fluidized Bed Combustion Cell manufactured by JWP Energy Products, Inc. (EPI) rated to produce biogas with a 94 million BTU per hour (94 MMBTU/hr) lower heating value. This rating is sufficient to generate the steam required for a 3,000 kilowatt steam turbine.

The gasification system uses chipped wood to produce a fuel gas and involves controlled decomposition of the wood in a oxygen-starved atmosphere. The wood chips are supported by a heated bed of sand suspended within a rising column of air, i.e., fluidized bed, to pyrolize or to gasify the wood fuel.

This process releases a low-BTU gas composed of carbon monoxide and hydrogen, with some higher order hydrocarbons, and normal products of combustion, carbon dioxide and water vapor. The resulting low-BTU gas is then pumped from the gasifier to a conventional industrial boiler where it is combusted and the resulting heat is utilized to generate steam. 


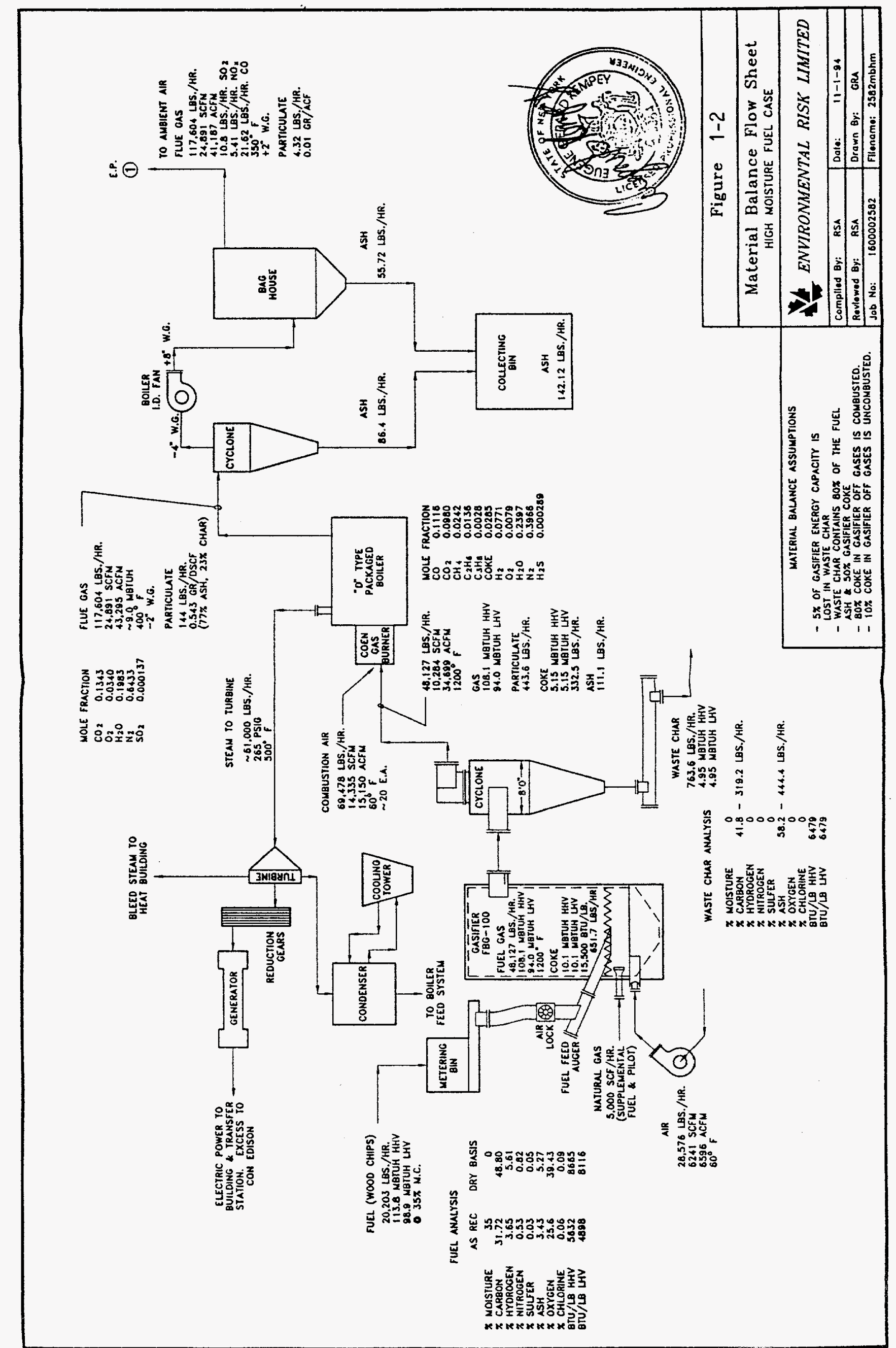




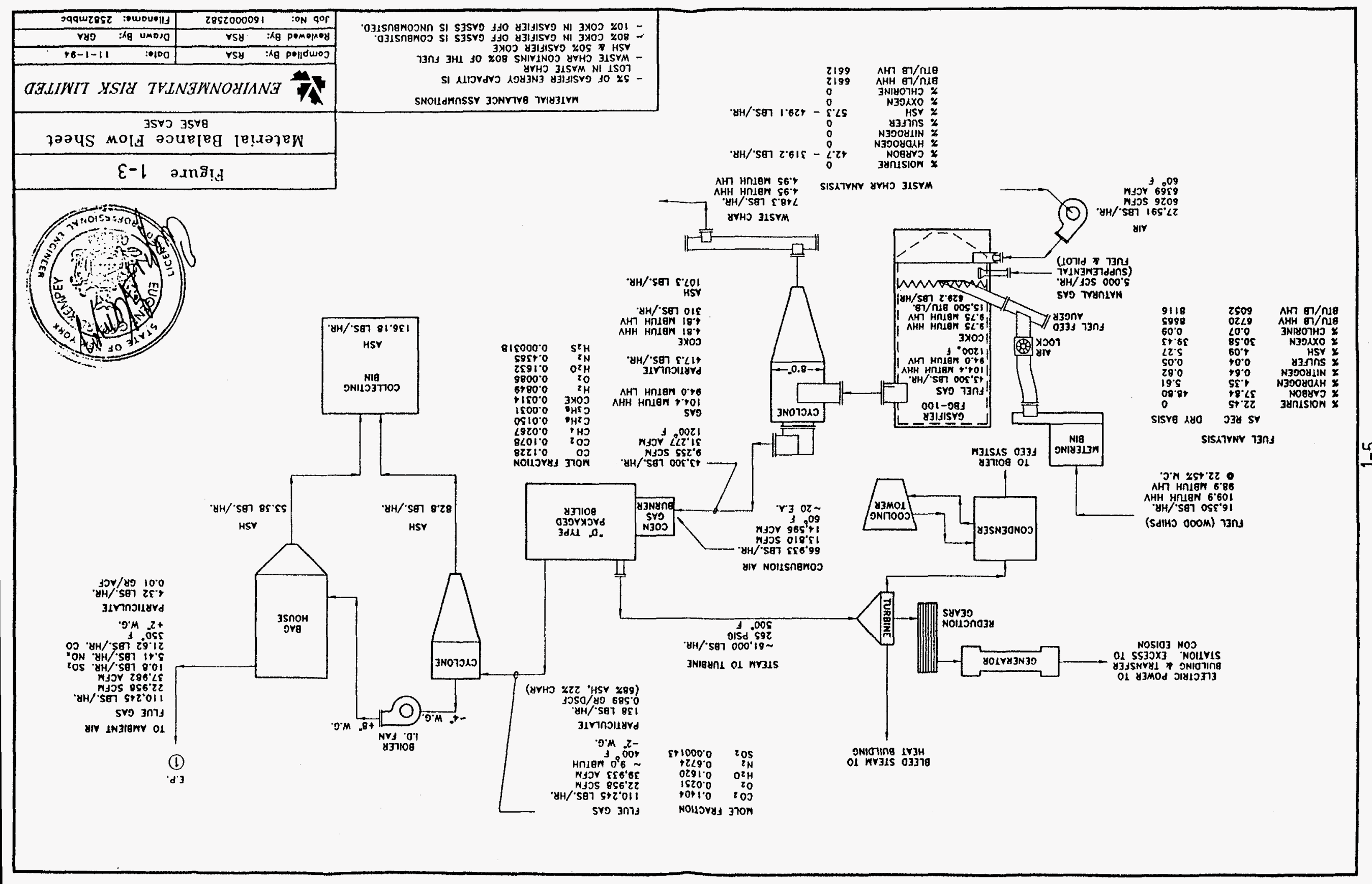




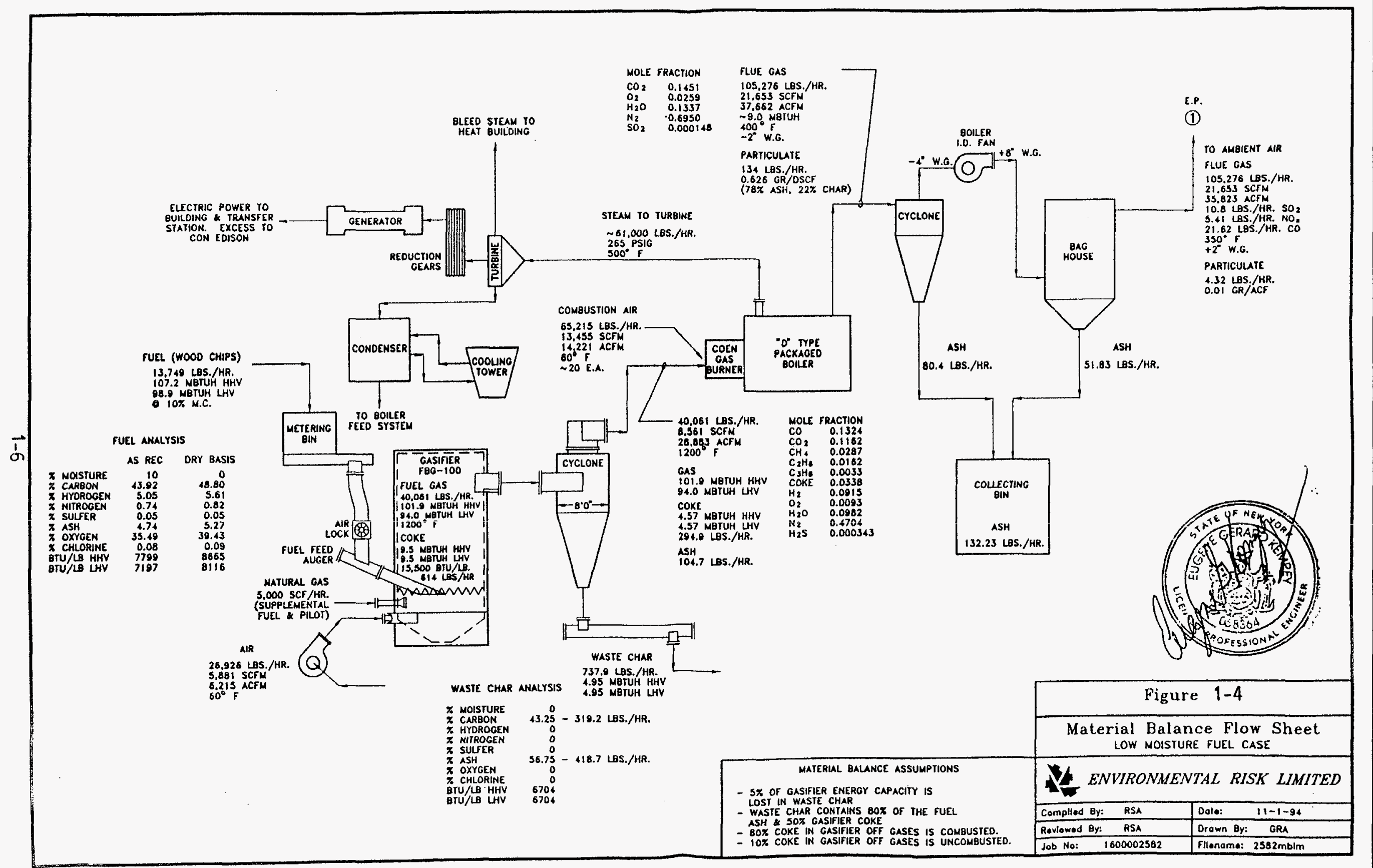


Wood gasification is a relatively pollution-free process and can be applied in environmentally sensitive areas. Emission controls ensure minimal particulate discharges and provide the boiler burner with clean gaseous fuel comparable to natural gas.

The gasification system and the wood handling system were originally constructed in 1988 by Alternate Gas, Inc. to produce low-BTU gas. The low-BTU gas was sold to the Golden Cat Corporation for use as a fuel in its kiln drying operations to process clay material to produce "kitty litter." The facility, located near Bloomfield, Missouri, was operated for approximately 14 months. Then, prevailing fuel oil prices to Golden Cat's evaluation that the low-BTU fuel did not meet its requirements and Golden Cat returned to using oil as the fuel for drying.

\section{Concepts of Biomass Gasification}

All biomass fuels contain water, with part of it "bound" in the fuel particle and the remainder of it "free" or clinging to the outer surface of the particle. Before any biomass particle can be ignited and bumed, all of the free water must be evaporated from the surface and most of the "bound" water must be driven off. While this is happening, the particle stays relatively cool, at approximately $200^{\circ} \mathrm{F}$. The rate at which the particle dries depends largely on the particle size and the temperature of the gas surrounding it. After the water has been driven off as steam, the temperature of the particle rises rapidly and the combustible volatile components begin to gas out. These volatiles represent a major portion of the heating value of the fuel.

After water and volatiles have been boiled off from the fuel particle, the remaining material is charcoal. Particles of charcoal burn more slowly, and due to their mass, burn in the fluidized bed, thus maintaining the bed temperature at a level that will auto-ignite the fuel and sustain the reaction.

In a pyrolysis or gasification system, the combustion process is intentionally prevented from going to completion by starving the reaction for the oxygen necessary to complete the combustion. Thus, volatile gases generated from heating the fuel particles exit the reaction vessel as a low-BTU gas. This gas is much like natural gas, but with only about one-tenth the heating value or BTU content, and a certain amount of ash and other particulates. The low-BTU gas can be ignited and burned external to the gasification vessel by providing the additional oxygen required and the necessary ignition source. In the Atlas system, the lowBTU gas is ignited in the boiler and the resulting heat used to generate steam.

The heat content of the low-BTU gas at the boiler burner inlet has two components: the "sensible" heat, or heat content relating to the high temperature of the gas (about $1200^{\circ} \mathrm{F}$ ); and the "potential" heat available from the gas (about 1600 BTU per pound) when the hot gas is ignited and burned in the boiler. It is the 
latter of these two components that provides the distinct advantages of gasification over the normal combustion processes:

a. Gasification produces a great deal more energy from a given area of a fluidized bed, which results in a much smaller combustion vessel for a given BTU output.

b. The gasification process results in a much lower total volume of the combustion products exiting the gasification vessel. Thus, the off-gas ducting can be much smaller between the gasification vessel and the gas burner.

c. It is usually easier to control the amount of excess air in the combustion of the low-BTU gas than it is in the normal combustion of a biomass fuel in a fluidized bed. The resulting lower excess air levels have a significant effect on the energy conversion efficiency.

\section{System Operation}

Biomass fuel in the form of clean chipped wood is delivered to the gasifier from the fuel receiving/storage system. The fuel is metered to the fluidized bed gasifier vessel so the energy output can be automatically controlled to meet the varying requirements for the low-BTU gas demand by the boiler. A fuel metering system (consisting of a variable speed metering screw, a rotary airlock feeder and a fuel injection auger), meters, transports, and injects the fuel into the reaction vessel. A combination of combustion and gasification of the material occurs in the vessel, part of it in the vapor space above the bed and the remainder in the fluidized bed.

A natural gas fired bed pre-heat combustor is used during the gasification start-up phase to raise the temperature of the bed from ambient to the auto ignition temperature to ignite the fuel. As biomass is added, the bed temperature continues to increase. Combustion becomes self-sustaining and the preheat combustor is shut off. Air to support the combustion/gasification process is introduced into the vessel by a high pressure fan through the fluidized bed.

The resultant hot low-BTU gases are directed through refractory lined and insulated ductwork to a cyclone separator (also refractory lined and insulated) to remove the particulates, and are then injected into the lowBTU gas burner at the boiler. The burner is specifically designed to burn the low-BTU gas. It will also incorporate a staged combustion low- $\mathrm{NO}_{\mathrm{x}}$ design with flue gas recirculation to maintain $\mathrm{NO}_{\mathbf{x}}$ emissions below the 25 TPY major source trigger level for sources located in a severe ozone non-attainment area.

The burner head also contains a natural gas pilot flame to ignite the low-BTU gas. Air to support the final combustion of the low-BTU gases is provided in the boiler. The resulting products of combustion are then exhausted to the atmosphere through the stack via a baghouse for particulates control. 


\section{BOILER}

The boiler will generate steam for use in a condensing steam turbine. A conventional " $D$ " type packaged water tube industrial gas-fired boiler fitted with a low-BTU gas burner will be used. A natural gas supply will be provided for the burner pilot flame. The boiler is rated at a nominal 61,000 pounds of steam per hour at $285 \mathrm{psig}, 500^{\circ} \mathrm{F}$, to supply the steam turbo-generator.

Two boiler feed pumps will be provided. Each pump will be rated at $100 \%$ of required capacity. Boiler feedwater make-up will be treated water from the domestic water supply.

Combustion gases will be exhausted through a baghouse for removal of residual particulate material.

\section{STEAM TURBO-GENERATOR}

A conventional condensing steam turbo-generator unit will be used. The generator is rated at 3,000 kilowatts $(\mathrm{kW}), 4,169$ volts, 3-phase, 60 hertz, 0.8 power factor.

\section{COOLING SYSTEM}

The condenser cooling water will be supplied using a new conventional evaporative cooling tower which will be located on the roof of the building. This will permit reuse of the cooling water.

\section{WOOD HANDLING SYSTEM}

Processed (clean and chipped) wood fuel will be delivered by Atlas Roll-Off from their adjoining facility with a front-end loader. The delivered fuel will be screened to remove oversized material and then conveyed to finished storage. A wheeled front-end loader will move the wood fuel from storage to the reclaimer; it will then be conveyed to the gasifier's fuel feed system. All wood storage and handling operations will be conducted indoors.

\section{ELECTRICAL SYSTEM}

Electrical switchgear and power transformers suitable for a power station of this type will be provided. The equipment will have normal warranties and performance guarantees. 


\section{INTERCONNECTION FACILITIES}

Interconnection will be provided as required by the Consolidated Edison Company of New York.

\section{WOOD FUEL DESCRIPTION}

Atlas will accept clean waste wood as the source of fuel to be gasified. The wood fuel will be supplied solely by the permitted Atlas Roll-Off Recovery and Recycling Facility (ARO), located on an adjacent property, and will be delivered by front-end loader to the Bio-Energy facility.

ARO currently collects construction/demolition (C/D) wood and other waste wood from dumpsters placed at job sites in the New York City area. ARO will establish a clean waste wood collection stream to provide source fuel for the Atlas project.

The following is a list of acceptable sources of wood fuel for the proposed facility:

Wood Fuel Sources: Unadulterated wood, wood chips or bark from land clearing, logging operations, utility line clearing and maintenance operations, pulp and paper production, wood products manufacturing, clean used pallets and wood working scraps.

Atlas will prepare a more detailed wood fuel source specification for ARO including identification of potential suppliers and submit it to NYSDEC for review and approval. Atlas will also work with ARO to establish an acceptable plan for delivery, inspection and acceptance of clean waste wood. ARO will visually inspect each load before it is unloaded at the storage area specifically assigned for clean waste wood. If a load is unacceptable, it is rejected and sent away or unloaded at other appropriate areas.

To maintain quality control, Atlas will perform constant visual inspections of the quality of the fuel supply as it is conveyed into the facility. If the inspector discovers minor, easily separated waste components that do not meet the definition of acceptable wood fuel, those items will be removed from the fuel stream by hand; if the contamination is unseparatable or inherent, the wood fuel will be returned to Atlas Roll-Off. Once the fuel is accepted at the Facility, it will undergo further processing to prepare the wood specifically for gasification (Atlas Roll-Off supplies wood to several other locations for other purposes). The fuel will pass under magnets remove ferrous metals such as nails and staples. Oversize pieces of wood will be segregated via a disc screen and reduced in size with a hammermill. The fuel will then be stored indoors at the Bio-Energy facility for a maximum of three days prior to gasification. During this period of time, 
Atlas will conduct wood sampling and analysis for contaminants (lead, arsenic, and pentachlorophenol) following procedures in a NYSDEC-approved wood sampling plan. 
Section 2

ENVIRONMENTAL PERMIT REQUIREMENTS

\section{INTRODUCTION}

One of the Contractor's major tasks for this project was to assist Atlas to obtain the environmental permits required for construction and operation of the Bio-Energy facility. The initial step in the environmental permitting of a project involves the preparation of a permit plan which identifies required permits and the key issues and difficulties.

This analysis involved a review of the applicable New York State Department of Environmental Conservation (NYSDEC) and New York City Department of Environmental Protection (NYCDEP) rules and regulations for air quality, water quality and solid waste. The contractor also contacted the appropriate agency representatives from the NYSDEC and the NYCDEP. From these reviews, contacts and analysis, the following information is identified and included in this permit plan:

- Required environmental and local permits and approvals;

- Responsible regulatory agencies and contacts;

- Project criteria which may result in specific permit requirements or additional levels of project review;

- Permit application requirements;

- Difficulties associated with obtaining the permits;

- Key issues which may be addressed by regulatory agencies and intervenor groups; and,

- $\quad$ Refined schedules to obtain required permits and approvals.

It should be noted that a draft permit plan was originally completed at the beginning of this project. It was subsequently updated after the most significant permitting efforts had been completed and, therefore, represents the actual permitting process. This section was updated after the NYSDEC had issued for publication the Notice of Complete Applications for permits to construct and operate a Stationary Combustion Installation and a Solid Waste Management Facility. The Notice of Complete Applications was subsequently rescinded due to a procedural error: draft permit conditions were not available for public review when the notice was published. 


\section{KEY ISSUES AND FINDINGS}

Based on the results of this environmental permit analysis and the actual permitting process for the Atlas facility, the following key permits and/or approvals are required:

1. Air permit to Construct and Operate a Stationary Combustion Source issued by NYSDEC;

2. Permit for a Solid Waste Management Facility - issued by NYSDEC;

3. Industrial Waste Discharge approval and Site Connection permit for discharge of process and domestic wastewaters and storm water from the property - issued by the New York City Department of Environmental Protection (NYCDEP); and

4. NYC DEP Installation Permit.

The following were identified as the most significant issues affecting the permitting of the facility:

Atlas initially proposed to use urban waste wood containing some treated wood components as fuel. However, NYSDEC has made the regulatory interpretation that a facility proposing to use other than clean wood fuel (e.g., proposing to use wood from construction/demolition debris and treated wood) will be subject to review as an incinerator in accordance with Part 219 of Title 6 of the New York Code of Rules and Regulations (6NYCRR Part 219). Due to the additional regulatory scrutiny, control requirements, and likely public opposition in an urban area, Atlas has decided to revise its acceptable fuel specification to include only clean wood chips. When the facility is constructed and operating, Atlas will consider modifying its permits to allow use of treated wood fuel.

Location of the facility in an air quality region that has been designated as non-attainment of air quality standards for carbon monoxide (CO) and ozone will result in stringent controls and low emission rates for $\mathrm{CO}$ and ozone precursors (nitrogen oxides and volatile organic compounds) for this relatively small emission source.

- Several factors contributed to significant delays in obtaining permits for this project. Atlas originally made application on January 27, 1992 and submitted revised applications in August 1993 and July 1994. A Notice of Incomplete Application and several requests for additional information or clarifications were issued by NYSDEC during this time frame. Initially contributing to this delay were incomplete and inaccurate technical information and analyses provided by Atlas' original consultants. However, the NYSDEC's regional office staff appeared overburdened and at times unable to understand the scope of the project or to make a decision. Communication between the regional and Albany NYSDEC staff also appeared to prolong the review process. This experience underscores the necessity for technically complete and 
consistent permit applications reflecting a thorough understanding of regulatory requirements and issues.

\section{BACKGROUND INFORMATION}

The following preliminary information on the proposed Atlas project formed the basis of the permit plan:

The project will be located at 895 Essex Street, Brooklyn, New York. The project will occupy approximately 0.367 acres, consisting of a 12,700 square foot building with a 3,300 square foot yard. The facility is located in an area which is zoned for light manufacturing (M1-1) in the southeast portion of Brooklyn.

- The project originally proposed to use urban recycled wood to produce manufactured gas. The gas will be the energy source for an electric generating power plant with a nominal capacity of 3000 kilowatts. Atlas Roll-Off Corporation will provide all of the chipped wood.

- The facility has a 15-year contract with the Consolidated Edison Company of New York to provide electric power at 2000 kilowatts. Additional electric power will supply electric power requirements of the facility itself. The plant's design is in excess of projected initial power needs to provide for future increases in power sales or local power use. Some portion of the power in the future may be used to supply the adjacent Atlas Roll-Off Company facility.

- The daily wood fuel requirement for the facility will be approximately 196.2 tons per day or approximately 64,452 tons per year at a 90 percent annual capacity factor.

- A conventional evaporative cooling tower will supply condenser cooling water. Water will be supplied thorough the city water supply; wastewater will be discharged to the combined sanitary/storm water system.

Expected emissions of regulated criteria pollutants from the facility are summarized in Table 2-1.

\section{AIR QUALITY PERMITTING}

According to the rules of the NYDEC (6 NYCRR Part 201), the owner of any air contamination source or stationary combustion installation must have a Certificate to Operate valid for a period up to three years. A new source or modification must first secure a Permit to Construct before construction can proceed. After construction is completed, the source owner must apply for and obtain a Certificate to Operate to 
Table 2-1

Atlas Bio-Energy Proposed Emissions Rates

Max. Heat Input $=108.1 \mathrm{MMBtu} / \mathrm{hr} \mathrm{HHV}$ wood gas

\begin{tabular}{|l|c|c|c|l||}
\hline Pollutant & $\begin{array}{c}\text { Emission Factor } \\
\text { lb/MMBtu }\end{array}$ & $\mathbf{l b} / \mathbf{h r}^{(\mathbf{l})}$ & $\mathbf{T P Y}^{(\mathbf{2})}$ & \multicolumn{1}{|c|}{ Basis } \\
\hline $\mathrm{PM}$ & 0.04 & 4.32 & 18.94 & $\begin{array}{l}\text { Wheelabrator (Baghouse vendor) } \\
\text { expected guarantee }\end{array}$ \\
\hline $\mathrm{NO}_{\mathrm{x}}$ & 0.05 & 5.41 & 23.67 & $\begin{array}{l}\text { Coen Co. (Bumer vendor) } \\
\text { expected guarantee for low-NO } \mathrm{x} \\
\text { burner }\end{array}$ \\
\hline $\mathrm{CO}$ & 0.20 & 21.62 & 94.70 & $\begin{array}{l}\text { Coen Co. (Burner vendor) } \\
\text { expected guarantee }\end{array}$ \\
\hline $\mathrm{HC}$ & 0.015 & 1.62 & 7.10 & $\begin{array}{l}\text { Coen Co. (Burner vendor) } \\
\text { expected guarantee }\end{array}$ \\
\hline $\mathrm{SO}_{2}$ & 0.10 & 10.81 & 47.35 & $\begin{array}{l}\text { Material balance and review of } \\
\text { wood combustion data }\end{array}$ \\
\hline
\end{tabular}

(1) $\mathrm{lb} / \mathrm{MMBtu} \times 108.1 \mathrm{MMBtu} / \mathrm{hr}$
(2) $\mathrm{lb} / \mathrm{hr} \times 8,760 \mathrm{hr} / \mathrm{yr} \frac{1 \text { ton }}{2000 \mathrm{lb}}$ 
commence operation. Combustion sources with maximum heat input rate greater than $1 \mathrm{MMBTU} / \mathrm{hr}$ are generally required to obtain permits.

Permit application requirements and the level of review depend on the size of the combustion installation. In addition, depending on the size of installation, either the NYCDEP or NYDEC will take the lead in reviewing the permit application and issuing the permit for a source located in New York City. Based on ERL's initial discussions with the NYDEC and NYCDEP, permit applications for combustion installations with rated heat input rates greater than $100 \mathrm{MMBTU} / \mathrm{hr}$ are typically reviewed by the NYDEC; smaller facilities are reviewed by the NYCDEP. Although the NYC DEP originally originally indicated that NYDEC would take the lead in permitting the Atlas facility, upon notice of complete applications by NYDEC, the NYCDEP also requested that an application for an installation permit be submitted.

As a combustion installation with a rated heat input rate of $108.1 \mathrm{MMBTU} / \mathrm{hr}$, the Atlas Bio-Energy project was required to apply for and obtain both a Permit to Construct and a Certificate to Operate. In order to obtain the required approvals, three copies of the application with supporting calculations, plans, specifications, and demonstrations must be sent to both the NYCDEP and NYDEC. The applications are sent to the NYSDEC Division of Regulatory Affairs, Region 2 - New York, Hunters Point Plaza, 47-40 21st Street, Long Island City, New York 11101 and to the NYCDEP Records Control Section, Bureau of Air Policy and Programs, 59-17 Junction Boulevard, Corona, NY 11368-5107.

Contents of a complete permit application for a Permit to Construct include permit application forms, heat input and emissions documentation, plans and specifications. In addition, for a major source (greater than $250 \mathrm{MMBTU} / \mathrm{hr}$ heat input for gas or oil; greater than $100 \mathrm{MMBTU} / \mathrm{hr}$ for solid fuel), an air quality impact evaluation must be included as part of the permit application. An air quality impact evaluation may also be required in cases where the NYDEC determines that emissions will likely cause air pollution or contravention of any applicable ambient air quality standards. At the agency's discretion, the permit applicant may also be required to perform an evaluation of hazardous air pollutants. In this case, the source must demonstrate compliance with short term and annual guideline concentration values in accordance with procedures contained in "Guidelines for the Control of Toxic Ambient Air Contaminants" (Air Guide-1).

Following is a discussion of the specific air quality regulations that a source must demonstrate compliance with, some of which, depending on project sizing and emissions, may pose significant issues for siting of a combustion facility in the New York metropolitan area.

\section{Non-attainment New Source Review}

The entire New York City area including the project location in Brooklyn is classified as severe-17 nonattainment for ozone and moderate nonattainment for carbon monoxide (CO). The project site is just 
outside of the nonattainment area for particulate matter (PM). For other pollutants, the air quality is either better than national standards or cannot be classified.

The most difficult obstacle to permitting a new combustion source in the New York City area will be complying with the new NYDEC regulations covering "new source review in nonattainment areas and ozone transport regions" (New 6 NYCRR 231). Even for a small plant the size of the Atlas project, the major facility size thresholds can be easily exceeded for $\mathrm{NO}_{x}$ and $\mathrm{CO}$. $\mathrm{NO}_{\mathrm{x}}$ and $\mathrm{VOC}$ are regulated as precursors to ozone formation and the major facility size threshold in a severe ozone nonattainment area is 25 tons per year. For $\mathrm{CO}$, the major source threshold is $\mathbf{5 0}$ tons per year. However, an exemption clause has been added to the most recent nonattainment new source review regulations pertaining to $\mathrm{CO}$, which exempts a source from applicability if it can demonstrate that $\mathrm{CO}$ emissions from the proposed source result in insignificant ambient air quality impacts.

Based on estimates of emissions from combustion of wood gas in the boiler, the Atlas project will be a major source for ozone as a result of $\mathrm{NO}_{\mathbf{x}}$ emissions, and $\mathrm{CO}$. $\mathrm{NO}_{\mathrm{x}}$ emissions are estimated at approximately 47 tons per year based on a standard burner design and a $0.1 \mathrm{lb} / \mathrm{MMBTU}$ emission factor. However, with a low- $\mathrm{NO}_{\mathbf{x}}$ burner design, including some flue gas recirculation, one potential burner supplier (Coen $\mathrm{Co}$.) expects that $\mathrm{NO}_{\mathrm{x}}$ emissions could be reduced to $0.05 \mathrm{lb} / \mathrm{MMBTU}$. This would bring potential $\mathrm{NO}_{\mathrm{x}}$ emissions under 25 tons per year and eliminate the need for expensive flue gas controls such as selective catalytic reduction. However, $\mathrm{CO}$ emissions are expected to be above 50 tons per year with the low-NO $\mathrm{x}_{\mathrm{x}}$ burner design. Therefore, for the Atlas project, a demonstration of insignificant $\mathrm{CO}$ impacts was required to obtain an exemption from the nonattainment requirements and avoid the need for an oxidation catalyst to reduce $\mathrm{CO}$ emissions to less than 50 tons per year. The Atlas project was able to demonstrate insignificant $\mathrm{CO}$ impacts.

Permit application requirements for a new source subject to the nonattainment provisions include securing emission offsets, certifying compliance with all applicable emission limitations and standards, demonstrating that Lowest Achievable Emission Rate (LAER) will be applied to control emissions of any major source of a nonattainment pollutant, and conducting an air quality impact evaluation (for emissions of PM-10 or $\mathrm{CO}$, if applicable).

\section{New Source Performance Standards}

The Atlas Bio-Energy Facility will be subject to the New Source Performance Standards (NSPS) for industrial-commercial-institutional steam generating units. Subpart $\mathrm{Db}$ covers units from $29 \mathrm{MW}$ (100 $\mathrm{MMBtu} / \mathrm{hr}$ ) to $73 \mathrm{MW}(250 \mathrm{MMBtu} / \mathrm{hr}$ ) in heat capacity; Subpart Dc covers units from $2.9 \mathrm{MW}$ (10 
$\mathrm{MMBtu} / \mathrm{hr}$ ) to $29 \mathrm{MW}$. Because the Atlas facility will be just over $100 \mathrm{MMBtu} / \mathrm{hr}$ on a higher heating value basis, Subpart $\mathrm{Db}$ will apply.

Subpart $\mathrm{Db}$ contains emission standards for sulfur dioxide $\left(\mathrm{SO}_{2}\right)$, particulate matter $(\mathrm{PM})$, and nitrogen oxides $\left(\mathrm{NO}_{\mathrm{x}}\right)$.

$\$ 60.42 \mathrm{~b}$ Standard for Sulfur Dioxide. Atlas Bio-Energy is exempt from the sulfur dioxide NSPS in subpart $\mathrm{Db}$. These standards apply only to facilities that burn either coal or fuel oil as part of their fuel mix. Atlas will only combust gas produced by the gasification of wood. However, even if the $\mathrm{SO}_{2}$ standard were applicable $(0.5 \mathrm{lb} / \mathrm{MMBtu})$, the proposed emission rate $(0.20 \mathrm{lb} / \mathrm{MMBtu})$ would easily comply.

$\$$ 60.43b Standard for Particulate Matter. The facility is subject to two separate sections of the NSPS for particulate matter. The first is paragraph (c)(1), which covers facilities that burn more than $30 \%$ wood and do not burn coal. This limits the facility to $43 \mathrm{ng} / \mathrm{J}(0.10 \mathrm{lb} / \mathrm{MMBtu})$ of particulate matter. With the baghouse proposed for particulate control, emissions will be well within compliance with this limit.

Paragraph (f) of this section also requires a facility that combusts wood to meet a limit of $20 \%$ opacity, determined on a six-minute average, with one allowable exceedance per hour of $27 \%$ opacity. Based on the baghouse proposed for control of particulates, compliance with this opacity limit should be easily demonstrated.

\$ 60.44b Standard for Nitrogen Oxides. The Facility is exempt from this standard, as no standard is given for a wood gas-fired boiler or one that simultaneously combusts gas or oil with wood if the annual capacity factor is less than 10 percent for gas or oil. The most stringent $\mathrm{NO}_{\mathrm{x}}$ emission limit in this section is for natural gas that has a low heat release rate; this limit is $43 \mathrm{ng} / \mathrm{J}(0.10 \mathrm{lb} / \mathrm{MMBtu})$. The proposed $\mathrm{NO}_{\mathrm{x}}$ emission rate for the Facility is $0.05 \mathrm{lb} / \mathrm{MMBtu}$, which would show compliance with this section if it were applicable.

\section{Prevention of Significant Deterioration (PSD) Review}

New stationary combustion installations or modifications of such sources are considered "major facilities" subject to Prevention of Significant Deterioration (PSD) requirements if the cumulative permissible emissions from the facility of pollutants for which an area has been classified as attainment exceed certain applicability thresholds. For a new source included in EPA's list of 28 regulated source categories, the applicability threshold is 100 TPY. For other source categories the applicability threshold is 250 TPY. Since wood gas is not considered a fossil fuel, no combustion facility fueled with wood gas, regardless of 
size, would be considered a listed source; therefore, the 250 TPY threshold should apply. Sources subject to PSD review are required as part of a complete permit application to include a Best Available Control Technology (BACT) determination, an air quality impact evaluation demonstrating compliance with PSD increments, an analysis of ambient air monitoring data, and an evaluation of the effects of the major facility on soil, visibility and vegetation.

Based on expected emissions of pollutants for which the project site area has been classified as attainment of national air quality standards, the Atlas facility will not be subject to PSD requirements.

\section{Fuel Composition and Use - Sulfur Limitations}

6 NYCRR 225-1 specifies the maximum allowable sulfur content of oil, coal, and "solid fuels." The Facility will combust a manufactured gas produced by the gasification of wood, which is not a fuel covered by this subpart. In the New York City area, sulfur in solid fuel can not exceed 0.2 pounds per million Btu gross heat content. The expected $\mathrm{SO}_{2}$ emission rate for the Facility is $0.20 \mathrm{lb} / \mathrm{MMBtu}$, which would be in compliance with this Subpart if the Facility were subject to it.

\section{Wood Source Considerations}

It generally has been difficult to permit wood combustors burning waste wood in New York State because the NYSDEC permits narrowly define acceptable waste wood to exclude painted wood, particle board or plywood, wood that has been coated, treated or contaminated with oil, finishes, glue, chemicals, or any other contaminants, wood chemically treated as a preservative, or any solid material that is not wood. Power plants proposing to burn any of these treated types of waste wood must demonstrate on a case-by-case basis that no adverse pollutant problems will occur. This is currently being done at several plants in New York by conducting test burns with specific waste wood types.

Emissions from combustion of wood gas in a boiler is much less understood than conventional wood combustion. Theoretically, it is possible that the lower temperatures of gasification compared to combustion result in lower potential emissions of contaminants, such as metals. However, no data have been found on metals emissions to verify this theory. Therefore, NYSDEC is regulating the allowable wood fuel types for the Atlas facility in the same manner that it regulates conventional wood power plants; i.e., clean/untreated wood fuel will likely be approved initially as a stationary combustion source. Use of treated waste wood will require permitting as an incinerator and test burns and emissions testing to demonstrate acceptability. 


\section{Status of Applications}

Atlas originally submitted an application for a Permit to Construct on January 27, 1992. Following several revisions and a Notice of Incomplete Application dated October 26, 1993, Atlas filed a revised application on July 1, 1994. A final revision was filed in November 1994 to reflect the change in allowable fuel to clean wood chips only. NYSDEC determined that the application was complete on March 21, 1995 and the Notice of Complete Application was published during the week of April 5, 1995.

The NYSDEC normally does not require public hearings for applications for minor projects such as the Atlas project. However, if a public hearing is required due to significant public opposition, it shall commence on or before 90 calendar days after the application is complete. The Uniform Procedures Regulations state that for a minor project for which no public hearing was held, the permit or permit denial should be issued on or before 45 days after the date that the application was complete. This schedule is extended to 60 days after receipt of the complete hearing record for any application for which a public hearing has been held.

Regulatory agency contacts for the preceeding:

Harold J. Dickey, Division of Regulatory Affairs, NYSDEC, Long Island City, 718-482-4997.

Anna Mendez, NYSDEC, Region 2, Long Island City, 718-482-4944.

Timothy Ross, P.E., NYSDEC, Albany, NY, 518-457-7688.

Tom Cullen, NYSDEC, Albany, NY, 518-457-7688.

Ray Hodges, NYCDEP, Bureau of Air Policy and Programs, Corona, NY, 718-595-3787.

\section{WATER AND WASTEWATER PERMITTING}

Permitting requirements for water supply and wastewater discharge are expected to be minimal for this project. Listed below are permits and approvals which are expected to be required for the project, along with a brief discussion of the issues and assumptions which are related to each. Permit application requirements are also included for each type of permit.

\section{NYCDEP Industrial Wastes Control Section Approval}

Because Atlas Bio-Energy will be generating industrial wastewater (e.g., boiler blowdown, cooling tower blowdown, floor drains discharges, etc.), the facility must submit a Wastewater Quality Control Application 
to the Industrial Wastes Control Section. This is the key wastewater approval which must be obtained for the facility, and this approval will include storm water runoff from the facility as well. According to the present design of the facility, all of the wastewater and storm water will be discharged into a combined sanitary/storm water system which connects to the local Publicly Owned Treatment Works (POTW) in Brooklyn. According to both the NYSDEC and the NYCDEP, the NYSDEC has delegated the permitting authority for POTW discharges to the NYCDEP.

This Wastewater Quality Control Application requires the following information: location; applicant; owner; project use; location plan showing existing sewers and proposed discharge locations; type of wastewater and proposed discharge rates; a description of the operations including a list of chemicals or hazardous materials or wastes stored or generated (including MSDSs); designs and specifications of any pretreatment systems (including oil/water separators, neutralization systems, etc.).

The NYCDEP Division of Drainage Basin Management is willing to hold a pre-application meeting to familiarize the agency with the project and to identify any potential problems or key items prior to submittal of the wastewater quality control application.

Because the facility is identified by the EPA as a Primary Industry (Steam-Electric Generating Facility) with effluent guidelines and standards, the application will most likely be reviewed by the NYCDEP's legal staff in the Enforcement and Compliance Section. This additional review may result in requiring estimated analytical data on the discharges, based on operating information from similar types of facilities.

The final approval from the Industrial Wastes Control Section will most likely either include or reference discharge limits for various parameters such $\mathrm{pH}$, oil \& grease, and several metals. Limits will most likely be based on the allowable levels as referenced in the current sewer regulations and effluent limitations per the EPA Effluent Guidelines and Standards for Steam Electric Power Generating Point Source Category. The facility may also be required to conduct some baseline monitoring.

The engineers contracted by Atlas Bio-Energy to develop the detailed design and specifications of the water and wastewater systems should be aware of the local and federal discharge limits which may be potentially applied to the wastewater discharges. If determined to be necessary, oil/water separators may have to be included in the design of the floor drains. Neutralization of any regeneration waste streams may be necessary. At the present stage of the facility's design, including any pretreatment systems has not been determined. However, assuming that the design engineers are familiar with potential qualitative discharge restrictions and include these as appropriate or necessary in the designs, difficulties in obtaining this approval from the Industrial Wastes Control Section are not anticipated. 
According to the NYCDEP, this industrial waste section approval is required for any facility with a process/industrial wastewater discharge to a separate or combined sewer system. Existing discharges are typically required to be analyzed as part of the approval process and, at a minimum, must meet the sewer ordinance limits for specific parameters. Concentrations for toxic substances (e.g. cadmium, chromium, copper, cyanide, lead, mercury, nickel, and zinc) and various other characteristics such as BOD, chlorine, suspended solids, $\mathrm{pH}$, flammability, and oil and grease are established in the New York City sewer regulations, although more stringent concentrations may be specified in a facility's approval. More specifically, if a type of facility falls into the category of a Primary Industry, then federal pretreatment standards may apply to that particular discharge, in addition to the local limits. The specific limits, as well as monitoring frequency, depend in part on the type of industry generating the discharge.

If a facility does not discharge any industrial/process wastewaters to a local POTW, but discharges only domestic wastewater, then the Industrial Wastes Section approval is not required.

According to the NYCDEP, one set of preliminary or draft drawings should be submitted initially; however, three original final sets of drawings with a P.E. certification will be necessary as the final submittal.

Regulatory agency contacts for the preceeding are:

Peter Garofalis, NYCDEP, Industrial Wastes Control Section, 96-05 Horace Harding Expressway, Corona, NY 11368, 718-595-4943.

Vincent Sapienza, NYCDEP, Industrial Wastes Control Section, 96-05 Horace Harding Expressway, Corona, NY 11368, 718-595-4950.

Robert LaGrotta, Esquire, P.E., Enforcement and Compliance, Bureau of Water Supply and Waste Water Collection, NYCDEP, Corona, NY, 718-595-4730.

\section{Site Connection Approval}

The Industrial Wastes Section approval must be obtained before issuance of the Site Connection Approval. Site Connection approval may not be required since this is a developed site with existing sewer connections. However, the approval form may be required if the surface of the site is changed, if a new sewer connection is proposed, if the building code requires it (i.e., if an addition is over a set size), or by the State's request such as referral from the Industrial Waste Division. The forms are reviewed within two weeks of submittal; certification may follow quickly or be delayed for insufficiency or if the legal review indicates legal issues which are not resolved. An example of the latter occurs when the facility does not have access fronting the sewers to which it proposes connecting. 
To receive this approval, six copies of the Site Connection Proposal Form and supporting plans and data must be submitted to the local borough sewer office of the NYCDEP (Brooklyn Sewer District). Some key information that must be included are detailed site plans showing discharge locations; storm flow directions; a current site survey; approval from the NYCDEP Industrial Waste Section; changes in street drainage; and P.E. signature.

According to the NYCDEP, all copies should be sent to the Brooklyn Sewer District Office, 210 Joralemon Street, Room 901E, Brooklyn, NY 11201. The Brooklyn Sewer District will then be responsible for forwarding a copy to the Division of Sewer Regulation and Control and to the Drainage Plans and Records Section, NYCDEP, in Corona, (Queens) New York. Site connection approval is valid for two years.

According to the NYSDEC, the facility is not required to submit a copy of the site connection approval form to the NYSDEC. However, the facility must submit a copy of the approval letter to the NYSDEC Division of Regulatory Affairs, NYSDEC, Region 2 - New York, City, Hunters Point Plaza, 47-40 21st Street, Long Island City, New York 11101.

The local sewer district and the drainage review section are primarily interested in the ability of the sewer system to handle the sanitary/domestic and storm water runoff; the only potential problem may be an increase in storm water runoff beyond the present existing quantity. Because the Atlas Bio-Energy facility will be located on a property which has already been developed and connected to the sewer system for both sanitary and storm water runoff, no problems or issues regarding the approval from the sewer district for a new or revised site connection are anticipated.

The primary interest of this regulatory agency, regardless of the type of facility, is the ability of the sewer system to handle the increased flow, in terms of domestic wastewater and, as appropriate, storm water (as opposed to industrial/process-type wastewater). Any facility must identify if the discharge location for storm water runoff from the property is into a separate or combined storm water system. If the system is a combined sanitary/storm water, per the above permit/approval, the applicant/facility is required estimate the quantity of storm water which will be discharged from the property under various storm events. The ability of the system to handle any increased flow is critical in the application process.

Regulatory agency contacts are:

Simon Gelin, Brooklyn Sewer District, NYCDEP, Brooklyn, NY, 718-802-3540. 
Vincent Malveaux, Division of Sewer Regulation and Control, NYCDEP, Corona, NY, 718-5955235.

Anthony Petriella, Permits Approval and Review Section, Bureau of Water Supply and Wastewater Collection, NYCDEP, Corona, NY, 718-595-5199.

John Ridgeway, Drainage Plans and Records Section, Division of Drainage Basin Management, NYCDEP, Corona, NY, 718-595-4182.

\section{Local Water Supply}

The NYCDEP Water Supply Section does not require submitting an application for water supply connection. However, final piping specifications must be reviewed to insure that a compatible hook-up/water line is available. Information about the proposed water use and the current water supply are unavailable for the Atlas Bio-Energy facility. When these specifications are available, Atlas Bio-Energy should review them with the Water Supply Distribution engineer for Brooklyn. The availability of water seasonal variations in water pressure should also be discussed.

Contacts per the above:

Frank Nestico, Water Supply Distribution engineer for Brooklyn/Queens, NYCDEP, 59-17 Junction Blvd., Corona, NY (718) 595-5770.

Herbert Kass, Chief of Water Supply Distribution, NYCDEP, 59-17 Junction Blvd., Corona, NY (718) $595-5751$.

\section{Evaluation of Other Permits}

The following summarizes the permits considered and/or evaluated as part of this permit plan but that were determined not necessary for this project, based on the current facility design.

- $\quad$ NYSDEC General Permit for Storm Water Discharges from Construction Activities The facility does not require a State Pollutant Discharge Elimination System (SPDES) General Permit for the storm water which would be associated with any construction activities at the facility because runoff from the facility discharges into a combined sanitary/storm system and combined systems are not covered under the New York SPDES program. (This SPDES storm water program applies only to point source discharges to surface waters or discharges through a municipal separate storm sewer system.) Storm water through a combined sanitary/storm water system is covered under the local NYCDEP sewer discharge approval as previously described.

As a general summary on the regulatory requirements for storm water discharges from construction activities, a steam electric generating facility, regardless of the fuel source, that discharges storm water from construction activities greater than five acres in area either directly to surface water or through a separate storm system (which ultimately discharges to a surface water) must submit a completed Notice of Intent (NOI). Because New York State is using EPA's information management system, the NOI must be sent 
to Storm Water Notice of Intent, P.O. Box 1215, Newington, VA 22122 rather than to the NYSDEC. This NOI must be submitted at least two days prior to starting construction. A Storm Water Pollution Prevention Plan must be developed for construction activities at the site and must identify potential sources of pollution. The plan must be developed prior to the submittal of the NOI and must include specific information items identified in the regulations such as erosion and sediment controls, site inspections, and maintenance. When the site has been stabilized and storm water discharges from the construction activities have been eliminated, the operator of the facility must submit a Notice of Termination (NOT) to the Storm Water Notice of Termination, Box 1185, Newington, VA 22122.

Regulatory agency contact per the above:

Chin Chakvabarti, Storm Water Specialist, NYSDEC, Long Island City, NY, 718-482-4933, ext. 7250 .

- NYSDEC General Permit for Storm Water Discharges Associated with Industrial Activity - The Atlas Bio-Energy facility does not require a State Pollutant Discharge Elimination Permit (SPDES) General Permit for the storm water runoff associated with the industrially-active areas of the facility per the above explanation, discharge to a combined sanitary/storm system.

However, if a steam electric generating facility discharges storm water either directly into surface water, into surface water via a separate storm water system, or into the groundwater, then the operator must file a NOI to the above address for construction activities. The facility must also prepare a storm water pollution/best management plan, which must be kept on file. Steam electric generating facilities are not typically required by the NYSDEC to submit monitoring data either to the EPA or to the NYSDEC. A NOT must also be filed to avoid annual billing when the facility ceases operations.

Regulatory agency contact per the above:

Chin Chakvabarti, Storm Water Specialist, NYSDEC, Long Island City, NY, 718-482-4933, ext. 7250 .

- Individual State Pollutant Discharge Elimination System Permit/NYSDEC - An individual SPDES permit from the NYSDEC is not required for the Atlas Bio-Energy facility because no wastewaters are being discharged to any surface water (either directly or through any separate storm system) or groundwater. Per the above discussion, wastewater discharges will be permitted under a NYCDEP Site Connection Permit and Industrial Wastes Section. If this type of facility discharges a non-storm water discharge to a surface water, separate storm system, or to groundwater, then it would be required to apply for an individual SPDES permit.

The current NYSDEC permitting program does not have any general water permits. Typical discharges associated with steam electric facilities are boiler blowdown, water treatment/softening regeneration wastewaters, non-contact cooling water, cooling tower blowdown, floor drain discharges, laboratory sinks, hydrotest water, air compressor wastewater, steam traps, etc. At a minimum, the facility would be required to submit Forms 1 and $2 \mathrm{C}$ (or 2D). Form 2C (or 2D) requires the characterization of the various discharges. The facility will be required to ensure that the discharges meet the New York State Water Quality Standards as identified in Title 6, Chapter X, Parts 700-705 for 
surface and groundwaters. The facility may also be required to meet the Federal Effluent Guidelines and Standards for Steam Electric Generating facilities for discharges such as once through cooling water, cooling tower blowdown, chemical metal cleaning wastes, etc.

In New York City, the SPDES permitting authority for strictly sanitary/domestic wastewater discharges (no industrial wastewater) to a septic system/groundwater lies between both the New York City Department of Health and the NYSDEC regional office. The original application must be submitted to the NYSDEC, with a copy to the NYCDOH. In Nassau and Suffolk Counties, the Nassau County Health Department and the Suffolk County Department of Health services typically administer the permitting program for discharges consisting of predominantly sewage wastewater. The local DOH and the NYSDEC should both be contacted to ensure that the appropriate regulatory agencies are involved in the permitting process.

Regulatory agency contact per the above:

Alexander Becker, Water Management, NYSDEC, Long Island City, NY, 718-482-4933 ext. 7240 .

- Freshwater and/or Tidal Wetlands Permits - The Atlas Bio-Energy facility is not located within freshwater or tidal wetlands; therefore, these permits are not applicable to the facility.

In the event that a steam electric generating facility is to be located within or adjacent to a tidal wetlands, then the facility may be required to obtain a tidal wetlands permit under Article 256 NYCRR 662,663 from the regional NYSDEC office. Tidal wetlands are tidal water state and the tidal marshes, flats and shoreline areas. The adjacent areas extend up to 300 feet inland from the wetland boundary and up to 150 feet inland within NYC. In the event that a steam electric generating facility is to be located within or adjacent to a freshwater wetlands, then the facility may be required to obtain a freshwater wetlands permit under Article 246 NYCRR 661 from the regional NYSDEC office. The adjacent areas extend up to 100 feet inland from the wetland boundary. The construction of a facility such as a steam electric generating plant, even in adjacent areas to wetlands, would be considered to be a presumptively incompatible use and would require the submittal of an application. Specific development restrictions apply. The proposed location of a facility in a tidal or freshwater wetlands may represent a potential major flaw in the project's permitting progression. A pre-application meeting in the project's early developmental stages with the appropriate Regulatory Affairs regional office of the NYSDEC would be strongly recommended.

Regulatory agency contact per the above:

Michelle Greene, Division of Regulatory Affairs, NYSDEC, Long Island City, 718-482-4997.

- Floodplain Management - The facility is not within a designated floodplain. According to both the NYSDEC and the NYCDEP, because the facility is not within a floodplain, no information specific to the location with reference to the floodplain, must be submitted to either agency.

According to the NYSDEC, floodplain issues had been the responsibility of the NYSDEC under the Floodplain Management Regulations and permit. However, the approval of the 
location of a facility within a floodplain is currently under the local environmental regulatory agency's responsibility. Each agency has its own interpretation of floodplain management and should be contacted as part of the permitting process to determine specific local requirements.

Regulatory agency contact per the above:

Michelle Moore (currently Harold Dickey), Division of Regulatory Affairs, NYSDEC, Long Island City, 718-482-4997.

Brian Ribner, Brooklyn Building Department, 718-802-3670.

- Protection of Waters (Article 15 6NYCRR 608) and 401 Water Quality Certification - The Protection of Waters permit is not required because the Atlas Bio-Energy project will not result in the construction of a dam, the disturbance of a stream bed or banks or the excavation or fill of navigable waters. The 401 Water Quality Certification is not required; the facility will not have a SPDES permit application, per the Clean Water Act, or other surface water quality related permits regarding surface waters.

In the event that the construction of a steam electric generating facility results in the modification or disturbance of a protected stream, its bed or bank, or requires the construction of any impoundment structure in or across a natural stream or watercourse, then the Protection of Waters application will have to be submitted to the regional NYSDEC office.

If the proposed facility requires the completion of a SPDES permit application or any other federally-required water-related permits, the applicant must submit a written statement requesting the issuance of a 401 Water Quality Certification to the regional NYSDEC. Typically, this certification unconditionally follows the approval of the other permits, with few, if any, additional information requirements.

- U.S. Army Corps of Engineers Permits/U.S. Coast Guard Review - These permits/reviews are not necessary for the Atlas Bio-Energy project because there are no water intakes or discharges into navigable waters, including coastal waters.

A facility with an intake structure on a navigable water may require a General (Nationwide) U.S. Army Corps of Engineers permit; the Corps should be contacted for a pre-application meeting to determine the need for this permit specific to the project. Key issues related are the design structure with reference to authorized depths, dredging, and the determination of any Corps wetlands. The Coast Guard review typically involves the review of the information included in the Army Corps permit. Coast Guard review is focussed primarily on the effects on navigation.

- Major Petroleum Facility License - This license applies only to facilities with more than 400,000 gallons of petroleum product. If a generating facility is expected to store more than this quantity, a request for this license from the NYSDEC must be submitted, including information on the facility and an SPCC Plan. 


\section{SOLID WASTE MANAGEMENT FACILITIES PERMITTING}

Title 6NYCRR Subpart 360-3 requires a permit for construction and operation of solid waste incinerators, refuse-derived fuel processing facilities, and solid waste pyrolysis units. The NYSDEC has made the determination that a solid waste permit is required for the Atlas Bio-Energy facility, an Article 27, Title 7, Solid Waste Management Facility (Operate) Permit. This Permit Application, also known as a part 360 engineering document, was originally submitted to the NYSDEC on November 30, 1992. Revised applications were submitted on August 23, 1993 and July 1, 1994. A final revision was filed in November 1994 to reflect the change in allowable fuel to clean wood chips only. NYSDEC determined that the application was complete on March 21, 1995 and the Notice of Complete Application was published during the week of April 5, 1995. After a 15-day response period, the agency will then make any technical comments.

According to the NYSDEC and based on review of the application, the Agency does not expect major technical issues which may interfere with the issuance of the permit. The NYSDEC does not expect any more significant comments on the Solid Waste Permit Application than were included in the prior Notice of Incompleteness. The most significant comments or issues were wood chip storage areas; ash residue removal procedures; noise levels at the facility; a facility monitoring and inspection plan; a contingency plan; and a waste control plan.

The main issue that could influence the issuance of this permit is public input/opposition. Public objections which arise during the 15-day comment period may result in a public hearing. The outcome of a public hearing may affect the project's progress.

The NYSDEC is the only regulatory agency involved in the solid waste permitting issues for this facility. The NYCDEP and the Brooklyn Department of Sanitation are not involved in the permitting process.

Without a public hearing, the Solid Waste Management Section estimated it would take several months for the permit to be issued.

Title 6NYCRR Subpart 360-3 describes the permitting requirements for construction and operation of solid waste incinerators, refuse-derived fuel processing facilities and solid waste pyrolysis units. Wood burning facilities typically fall into one of these three categories. The majority of solid waste management facilities require a permit, although certain regulated facilities may be eligible for registration rather than a permit. With specific reference to wood burning units, there is only one specific unit eligible for a registration. This 
unit must meet these provisions: An energy recovery incinerator or pyrolysis unit that accepts off-site generated solid waste as alternate fuels provided the waste is nonhazardous, nonputrescible, recognizable, unadulterated and uncontaminated; the waste must be stored on surfaces that minimize leachate release; all leachate must be collected and treated; an annual report must be submitted to the NYSDEC; and samples must demonstrate that the waste fuels have a minimum heating value of 4000 BTU per pound, as received.

However, it should be noted that even if the facility meets all of the "registration" requirements above, the NYSDEC still has the authority to require a solid waste application and permit, as in the Atlas project. Typically, if other permits are required, a solid waste application will be required, even if a registration would fulfill the requirements.

Regulatory agency contacts are:

Gubbi Murthy, Solid Waste Management, NYSDEC, Long Island City, NY, 718-482-4994.

Charles Williams, P.E., Div. of Solid Waste, NYSDEC, Albany, NY, 518-457-7336.

\section{MISCELLANEOUS APPROVALS/SUBMITTALS}

In addition to the wastewater, air and solid waste permitting issues previously identified, there are several other forms/submittals required for the Atlas Bio-Energy project.

\section{Environmental Assessment Forms}

A full Environmental Assessment Form (EAF) was submitted to the NYSDEC April 21, 1992. The project proceeded under the State Environmental Quality Review (SEQR) program.

\section{State Environmental Quality Review Process}

A coordinated review of the proposed project is undertaken by NYSDEC under the direction of the Lead Agency established under an agreement within various NYSDEC agencies. The Lead Agency then determines whether the facility will (Positive Declaration) or will not (Negative Declaration) have a significant impact on the environment. A Negative Declaration completes the review process. 
The final SEQR determination was that this project is an unlisted action that will not have a significant effect on the environment. A negative declaration is on file. Therefore, no coordinated review was performed.

If a project receives a Positive Declaration under the SEQR process, a draft Environmental Impact Statement (EIS) would need to be prepared by the project proponents. The draft EIS goes under Lead Agency review and, after acceptance by the Lead Agency, is sent for Public Review. After a final EIS has been filed, each of the involved agencies will make positive or negative findings statements, either for the approval or the denial of the final project.

Regulatory agency contact is:

Michelle Moore (currently Harold Dickey), Division of Regulatory Affairs, NYSDEC, Long Island City, 718-482-4997.

\section{SPCC Plan}

Although not considered an approval or a permit, a Spill Prevention, Control and Countermeasure (SPCC) Plan would be required if the Atlas Bio-Energy facility installs aboveground storage for petroleum products in a quantity exceeding 1,320 gallons, or below ground storage exceeding 42,000 gallons. This plan is required by federal regulations, 40 CFR Part 112. Because the Atlas project will use natural gas for pilot and supplemental fuel in the gasifier and boiler proposed for the Atlas project, an SPCC Plan is not required.

\section{Local Approvals}

Local approvals are:

-Certificate of Occupancy;

-Plumbing Applications; and

-Mechanical Equipment Specification Submittal.

These approvals should be submitted by the contractor responsible for the facility construction/modifications. Regulatory agency contact is:

Brian Ribner, City of Brooklyn Building Department, Brooklyn, 718-802-3670. 


\section{CONCLUSIONS}

Based on the Contractor's interpretation of the NYSDEC and NYCDEP regulations, understanding of the proposed project, and familiarity with permitting wood-fired power plants, the following conclusions can be made with respect to the required environmental permits and regulatory issues pertaining to the development of the Atlas Bio-Energy project:

- There are no fatal technical flaws which were identified relating to the NYSDEC or the NYCDEP environmental permitting of the facility; however, public opposition is a potential problem;

- The facility is required to obtain an air permit to construct, and a certificate to operate from the NYSDEC air unit.

- Location of the project in a severe-17 ozone and moderate CO nonattainment area will result in stringent controls for this relatively small emission source. A low- $\mathrm{NO}_{\mathrm{x}}$ burner will be required to reduce $\mathrm{NO}_{\mathrm{x}}$ emissions to less than 25 TPY. For $\mathrm{CO}$, either a demonstration of insignificant ambient $\mathrm{CO}$ impacts or the addition of a $\mathrm{CO}$ oxidation catalyst is required to avoid nonattainment new source review requirements.

- The source will not be subject to PSD review; other NSPS and State regulations should not present problems in demonstrating compliance.

- The Atlas facility originally proposed to use urban waste wood containing some painted and treated wood components as fuel. The NYSDEC determined that the use of wood fuel obtained from these sources would subject the facility to permitting as an incinerator. Therefore, Atlas has decided to restrict the allowable wood fuel to only clean waste wood sources.

- The NYSDEC determined that the facility is required to obtain a Solid Waste Facility permit; the permit is not expected to contain atypical or unusual requirements, and that the primary requirements have already been identified in written comments from the NYSDEC Solid Waste Unit to Atlas Bio-Energy;

- Because the facility will use city water and discharge to a combined sanitary/storm water system, potential problems regarding intake structures and discharge points (i.e., to surface water) are essentially eliminated;

- The facility will be required to obtain an industrial waste discharge approval and possibly a site connection permit from the NYCDEP to discharge process and domestic wastewaters and for storm water runoff;

- The facility will be required to notify the local water supply utility regarding additional water needs for operation of the facility. 


\section{Section 3}

\section{WOOD FUEL CHARACTERIZATION}

\section{INTRODUCTION}

This section discusses data on the physical and chemical properties of waste wood and combustion ash specific to the New York City region. This data was used in the design and operational planning of the Atlas Bio-Energy gasification power project proposed in Brooklyn, New York. This section presents the results of fuel characterization tests performed on samples of clean wood and demolition wood taken at a New York City wood processing facility.

The Contractor obtained for analysis eight representative one-gallon incremental samples and approximately 150 pounds of mixed sample for each wood type from the wood storage piles at the recycling facility. Of the eight incremental samples, five individual fuel samples were tested for six key metals (arsenic, lead, chromium, titanium, zinc and mercury) to indicate fuel variability in each fuel type. Individual fuel types were then composited and the composite samples analyzed for:

- Ultimate/proximate;

- Chlorine;

- Laboratory ash fusion temperature; and

- Ten metals (arsenic, lead, chromium, titanium, zinc, mercury, barium, cadmium, copper and nickel).

The larger waste wood samples, burned in the Contractor's pilot-scale furnace to obtain more representative ash material, were analyzed for:

- Ten metals (arsenic, lead, chromium, titanium, zinc, mercury, barium, cadmium, copper and nickel);

- $\quad$ TCLP (Arsenic, Barium, Cadmium, Chromium, Lead, Mercury, Selenium, Silver);

- Minerals in Ash Analysis.

\section{SAMPLE COLLECTION}

This task's objective was to collect and analyze representative samples of clean and demolition waste wood from the New York City region. The recycling facility is a waste wood processor that receives wood from various sources throughout the city and processes the material into either wood chips or fuel pellets depending on the grade of the wood. To ensure that high quality fuel pellets are produced, clean and demolition wood received at the processing site is carefully segregated, inspected, and processed separately. 
The clean wood received by the processor consists of used pallets and shipping boxes which are free of any non-wood materials such as paper, sand, and gravel. The raw clean wood does contain some nails and other fasteners which are removed during chipping by a magnetic separator. The demolition wood received is mixed waste wood which goes through a manual picking station to remove non-wood materials and painted and chemically treated wood.

Eight one-gallon samples and one 150-pound sample were collected for each wood type. Based upon the Contractor's prior experience conducting waste wood analysis studies, a minimum of 5 samples is recommended for testing to achieve a $90 \%$ confidence that any sample would be within $\pm 100 \%$ of the mean. Five samples are typically required for processors doing a good job in controlling and processing the type of wood they accept. Eight samples are typically required for processors controlling their product quality but with a larger variability in the fuel and processing methods. Samples were collected at different locations throughout the processing site to be representative of as many different processing periods as possible and to provide a more realistic characterization of the fuel from each source.

\section{VISUAL INSPECTION}

Each sample was visually inspected before it was sent to a laboratory for analysis or bumed for ash. The clean wood samples were very uniform and contained no visible non-wood contaminants other than nails. There were no nails visible in the one-gallon samples and very few visible in the 150-pound sample. However, after the large sample was burned, there were about 25 nails in the ash. This metal, which cannot be processed by the laboratory for analysis, was sifted out using a one-quarter-inch mesh screen before sending the ash for analysis. Visual inspection also indicated there was not any painted or chemically treated wood, either creosote (very dark color and characteristic smell) or pressure treated wood (typical green or blue tinge to wood), in the chipped fuel.

The demolition wood samples were carefully reviewed for non-wood constituents and for typically nonpermitted wood types such as pressure-treated, creosote, and painted wood. In general, the kinds of unwanted materials found in the samples were bits of plastic, countertop material, small amounts of tar paper and shingles, and painted wood. There were also visible pieces of creosote treated wood and pressure treated wood in the samples. 


\section{TESTING PROCEDURES}

Sample blending and analysis procedures for the incremental samples are illustrated in Figure 3-1. Fach one-gallon sample was ground into splinters less than one inch long and well mixed. A portion ot each sample was then removed and analyzed for total concentrations of arsenic, chromium, lead, mercury, titanium, and zinc. With the exception of mercury, these metals were chosen because they are characteristic of certain types of waste woods. Arsenic and chromium are characteristic of chromated copper arsenate (CCA) pressure treated wood. Titanium, lead, and zinc are characteristic of painted wood. Because mercury contamination is typically a specific concern, the analysis for mercury used a low detection limit of $0.02 \mathrm{ppm}$. To convert this data to an ash basis, the percent by weight ash of each sample was also determined.

The remainder of the ground samples for each fuel type were combined into one large sample and again thoroughly mixed. This material was divided in half and from each half a combined sample was taken and analyzed for ultimate/proximate characteristics, weight percent chlorine, ash fusion temperatures, and total elemental concentrations of arsenic, lead, chromium, titanium, zinc, mercury, barium, cadmium, copper and nickel.

To provide ash data that may be more representative of full scale furnace combustion, the bulk samples ot each wood type were reduced to ash in the pilot scale furnace. The quantities of material sampled, when burned, provided enough ash to perform a variety of analyses. The ash generated for each wood type was split into two samples and sent to a laboratory for identical analysis. The ash from both wood types underwent the following tests:

- Total Elemental Concentrations of: Arsenic, Chromium, Lead, Mercury, Titanium, Zinc, Cadmium, Copper, Nickel and Barium.

- Toxic Characteristic Leachate Procedure (TCLP) for EPA criteria metals only: Arsenic, Barium, Cadmium, Chromium, Lead, Mercury, Selenium, and Silver.

- Minerals in Ash Analysis (MAA) which characterizes the main constituents of the ash.

Fuel and ash samples were analyzed by Commercial Testing and Engineering, a testing laboratory that primarily uses the American Society for Testing and Materials (ASTM) laboratory methods and protocols. The following sections describe the analyses performed and the methods used. 
Figure 3-1

Waste Wood Fuel Characterization Study (Blending and Analysis Sequence For Each Wood Sample)

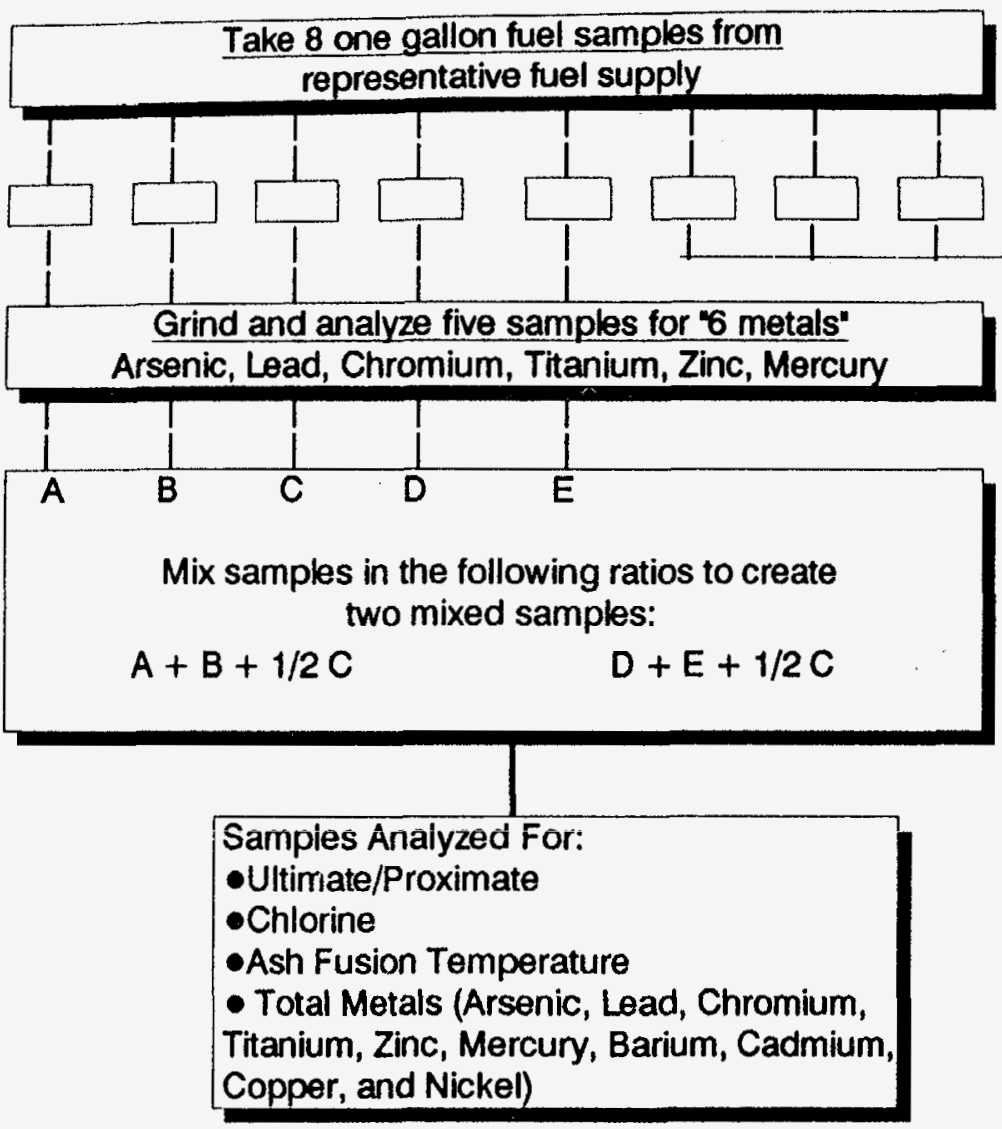
two mixed samples:

\begin{tabular}{|l|}
\hline Retain for \\
possible \\
future \\
analysis \\
\hline
\end{tabular}

\section{0 to 200 Pound Wood Sample}

Bum sample in Pilot Combustion System to produce ash.

Anaiyze duplicate samples of the ash for: - TCLP Metals Only

- Total Metals (Arsenic, Lead, Chromium, Titanium, Zinc, Mercury, Barium, Cadmium, Copper, and Nickel)

- Minerals

Analyze the flue gas for:

Carbon dioxide, carbon monoxide, oxygen, particulate emissions, total metals and volatile metals which could escape particulate collection. Analyze particulate and volatiles for arsenic, lead, chromium, titanium, zinc, mercury, barium, cadmium, copper, and nickel. 


\section{Wood Analyses}

Trace Elemental Analysis. This series of tests determines the concentrations of each of the following elements in the sample.

On a dry wood basis, $\mu \mathrm{g} / \mathrm{g}(\mathrm{ppm})$ :

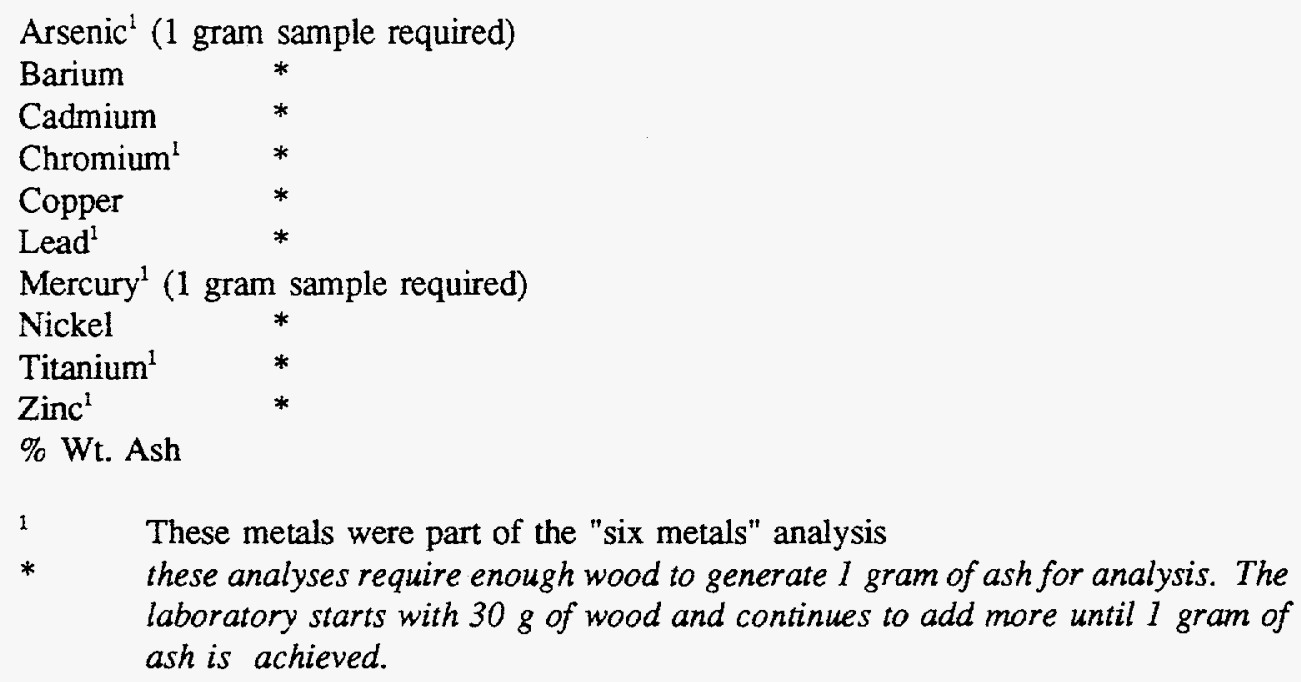

All metals were measured using ASTM D3683, except for the following: Arsenic, graphite furnace atomic absorption; and mercury, double gold amalgamation, and cold vapor atomic absorption. Percent ash was measured with ASTM D3174 or ASTM D1102. ASTM D3683 requires taking a wood sample and reducing it by slow combustion in a muffler furnace at $550^{\circ} \mathrm{C}$ to minimize metal volatilization, and then analyzing the remaining ash. The concentration on a dry wood basis is then calculated from the percent by weight ash in the wood.

Ultimate/Proximate (5 gram sample weight). The ultimate/proximate test is routinely performed on combustion fuels to determine the properties important to the design of the combustion system. The results of this test are not significantly affected by individual sample differences within fuel types when the results are adjusted to a moisture- and ash-free basis; therefore, only composite samples were analyzed.

This test measures the following items:

On a percent by weight basis, as received and dry:

$\begin{array}{ll}\text { Ash } & \text { Nitrogen } \\ \text { Carbon } & \text { Oxygen } \\ \text { Fixed Carbon } & \text { Sulfur } \\ \text { Hydrogen } & \text { Volatiles } \\ \text { Moisture (as received only) } & \end{array}$

Heating Value on a Btu/b basis, as received and dry. 
The analysis was primarily performed under ASTM D3173 and its associated methods. Individual methods were: moisture, ASTM D2016; ash, ASTM D1102; volatiles, ASTM D3175; fixed carbon calculated by ASTM D3172; Btu/lb, ASTM D2015 or ASTM D3286; sulfur, ASTM D4239 (Method C); carbon and hydrogen, infrared detection; and nitrogen, thermal conductivity.

Chlorine (2.5 gram sample weight). Chlorine testing was added to the ultimate/proximate tests. Knowing the quantity of chlorine and sulfur in the fuel is important to evaluate potential emissions of acid gases. Chlorine was measured on a percent by weight basis, both as received and dry, and was tested using either ASTM D4208 (Ion Selective Probe) or ASTM D2361 (Eschka).

Laboratory Ash Fusion Temperature (requires enough wood to produce 1 gram of ash). Ash fusion temperatures are useful to determine burn characteristics of a fuel and the potential for slagging and fouling in the furnace. This test measures the initial deformation, softening, hemispherical, and fluid conditions in degrees Fahrenheit under reducing and oxidating atmospheres using ASTM D1857.

\title{
Ash Analyses
}

Mineral ( 2 gram ash sample required). This test was used to determine the bulk composition of fuel ash generated in the pilot plant combustor. Samples were tested for percent metal oxides by weight of the Group One oxides, listed below. When the "undetermined" value was considered to be too large, analyses for the Group Two oxides were performed one by one until the undetermined quantity is considered acceptable.

\author{
Ignited Basis, \% weight \\ Carbon dioxide \\ Group One \\ Alumina Silica \\ Calcium oxide Sodium oxide \\ Iron oxide $\quad$ Sulfur Trioxide \\ Magnesium oxide Titanium \\ Phosphorus pentoxide Undetermined \\ Potassium oxide \\ Group Two \\ Barium oxide \\ Manganese oxide \\ Strontium oxide
}


All oxides are measured by ASTM D3682, except for the following: phosphorus pentoxide, ASTM D368278; sulfur trioxide, ASTMD 1757; and barium oxide and strontium oxide, ASTM D3683. Carbon dioxide was measured by ASTM C25.

Trace Elemental Analysis. This series of tests determines the concentrations of each of the following elements in the sample:

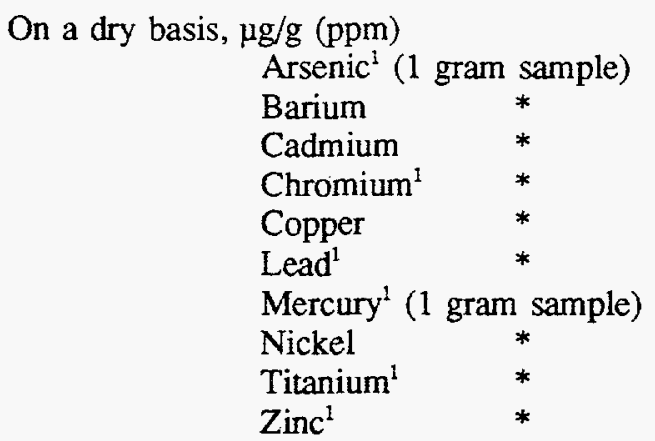

1 These metals were also part of the "six metals" analysis.

* $\quad$ indicated metals are all analyzed for using 1 gram of ash

All metals were measured using ASTM D3683, except for the following: arsenic, graphite furnace atomic absorption; mercury, double gold amalgamation and cold vapor atomic absorption. Typically when the laboratory receives an ash sample for metals analysis, they extract a portion and heat it to $750^{\circ} \mathrm{C}$ to complete the combustion of any unburned carbon before making metals measurements (with the exceptions of arsenic and mercury).

Toxic Characteristic Leaching Procedure (TCLP) (Metals Only - 100 gram ash required). The United States Environmental Protection Agency (EPA) Test Method 1311, also known as the Toxic Characteristic Leaching Procedure (TCLP), is used to determine if a waste should be considered hazardous by subjecting the ash to a fluid representative of the most effective leachate generated by a landfill, and comparing the concentrations of toxics in the leachate to allowable levels. Based on the Contractor's experience with wood, only the metals portion of the TCLP was performed.

Metals, $\mathrm{mg} / 1$ in leachate

Arsenic

Barium

Cadmium

Chromium

Lead

Mercury

Selenium

Silver 


\section{PILOT-SCALE COMBUSTION TESTS}

The Contractor's pilot-scale combustion test facility was used to generate waste wood ash for laboratory analyses. These waste wood materials are burned at conditions similar to that in a full-scale wood fired power plant. The furnace consists of an approximate four cubic foot firing chamber lined with fire brick, an undergrate auxiliary propane burner, and a stack with a variable-speed induced draft fan. Prior to combustion testing, the firing chamber is blown clean with compressed air. The facility is then warmed up on propane gas to heat the firing chamber. Fuel is fed into the firing chamber through a front-loading chute which can be closed to restrict airflow. The propane burner remains on throughout testing of high moisture or difficult to burn fuels to maintain fumace temperatures. When self-sustaining, dry fuels are burned, the burner flame is reduced entirely once a steady bed of ccals has formed. Reducing propane flow provides more oxygen to the fuel, allowing higher feed rates and combustion temperatures. Air flows are controlled by slide damper gates and a variable-speed induced draft fan. Fuel feed and air flow rates are varied to provide enough air for complete combustion and to minimize the entrainment of ash in the stack gases. At the completion of the fuel supply, the propane burner is relit to obtain complete combustion of the remaining material. When the facility has cooled, the entire inner surface of the firing chamber is vacuumed clean with a Shopvac equipped with an additional filter to prevent sample loss.

During fuel combustion, exhaust gases undergo Orsat analysis for $\mathrm{O}_{2}, \mathrm{CO}_{2}$, and $\mathrm{N}_{2}$. This information is used to adjust the system to burn the fuel as efficiently as possible. For the ten metals selected for this study, total suspended particulate matter (TSP) and condensible particulate emission rates were measured using a modified EPA Method 5 sampling train as described in the CFR, Title 40, Part 60.

A schematic of the train is shown in Figure 3-2 and consists of a sample nozzle, a glass particulate catch filter, four impingers, vacuum pump, dry gas meter, and an orifice flowmeter. Air is drawn from the stack and passes through a heated glass filter which catches particulate. The air then passes through the four impingers, which are in an ice bath to capture gas vapor emissions. To capture mercury, one of the impingers is filled with $\mathrm{KMnO}_{4}$ in solution. Material collected on the filter and the sampling line rinse is known as front half particulate. The material collected by the impingers is known as back half condensibles. The front half and back half of each test were analyzed for each of the ten metals selected for this study.

Two emission test runs were conducted for each fuel type. The results of the Orsat and particulate tests are summarized in Table 3-1. These results are reasonably comparable since fuel feed rates and operating conditions varied only slightly between the tests. The one exception is that stack temperatures varied over 

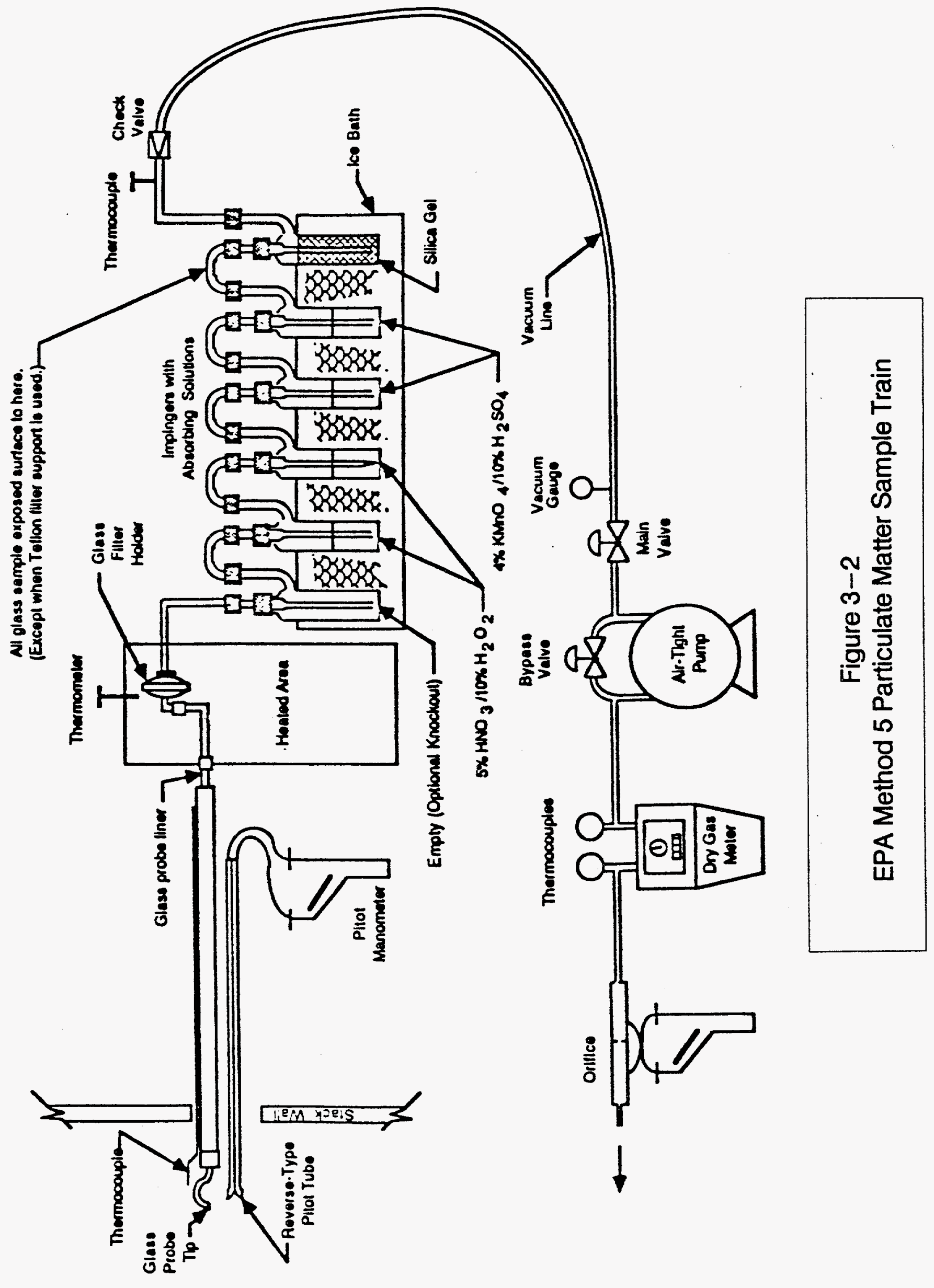
Table 3-1

Stack Test Results

Pilot-Scale Combuster

\begin{tabular}{|c|c|c|c|c|c|c|}
\hline & $\begin{array}{c}\text { Clean Wood } \\
\text { Run } 1\end{array}$ & $\begin{array}{c}\text { Clean Wood } \\
\text { Run } 2\end{array}$ & $\begin{array}{c}\text { Clean Wood } \\
\text { Average }\end{array}$ & $\begin{array}{c}\text { Construction/ } \\
\text { Demolition Run } 1 \\
\end{array}$ & $\begin{array}{c}\text { Construction/ } \\
\text { Demolition Run } 2 \\
\end{array}$ & \begin{tabular}{c|} 
C/D \\
Average \\
\end{tabular} \\
\hline $\begin{array}{l}\text { Burn Duration, hrs } \\
\text { Total Wood Feed, Ib } \\
\text { Average Wood Feed, Ib/hr } \\
\text { Test Duration, hrs } \\
\text { Stack Temperature, }{ }^{\circ} \\
\% \mathrm{CO}_{2} \text { in stack gas, dry basis } \\
\% \mathrm{O}_{2} \text { in stack gas, dry basis } \\
\% \mathrm{~N}_{2} \text { in stack gas, dry basis } \\
\% \mathrm{H}_{2} \mathrm{O} \text { in stack gas }\end{array}$ & \begin{tabular}{r|}
2.68 \\
38 \\
14.2 \\
0.98 \\
604 \\
2.3 \\
17.3 \\
80.4 \\
5.14
\end{tabular} & $\begin{array}{r}3.42 \\
52 \\
15.2 \\
1.05 \\
425 \\
2.4 \\
17.3 \\
80.3 \\
4.87\end{array}$ & & $\begin{array}{r}2.3 \\
43.5 \\
18.9 \\
1.07 \\
635 \\
4.1 \\
16.2 \\
79.8 \\
4.5\end{array}$ & $\begin{array}{r}2.95 \\
58 \\
19.7 \\
1.42 \\
800 \\
4.8 \\
15.6 \\
79.5 \\
4.82\end{array}$ & \\
\hline \multicolumn{7}{|c|}{ Total Metals Emissions, Particulate Filter } \\
\hline $\begin{array}{l}\text { Arsenic, lb/hr } \\
\text { Lead, lb/hr } \\
\text { Chromium, } \mathrm{b} / \mathrm{hr} \\
\text { Titanium, Ib/hr } \\
\text { Zinc, Ib/hr } \\
\text { Barium, lb/hr } \\
\text { Cadmium, Ib/hr } \\
\text { Copper, lb/hr } \\
\text { Nickel, lb/hr } \\
\text { Mercury, lb/hr } \\
\end{array}$ & \begin{tabular}{|r|}
$1.71 \mathrm{E}-04$ \\
$4.34 \mathrm{E}-04$ \\
$2.46 \mathrm{E}-04$ \\
$2.06 \mathrm{E}-05$ \\
$5.26 \mathrm{E}-04$ \\
$1.89 \mathrm{E}-05$ \\
$1.03 \mathrm{E}-05$ \\
$<1.83 \mathrm{E}-06$ \\
$1.26 \mathrm{E}-04$ \\
$<1.26 \mathrm{E}-06$ \\
\end{tabular} & $\begin{array}{r}6.38 E-05 \\
1.51 E-04 \\
6.38 E-05 \\
2.32 E-05 \\
3.71 E-04 \\
2.78 E-05 \\
9.86 E-06 \\
3.94 E-06 \\
5.80 E-05 \\
<3.77 E-06 \\
\end{array}$ & $\begin{array}{l}1.17 E-04 \\
2.93 E-04 \\
1.55 E-04 \\
2.19 E-05 \\
4.49 E-04 \\
2.34 E-05 \\
1.01 E-05 \\
2.89 E-06 \\
9.20 E-05 \\
2.52 E-06\end{array}$ & $\begin{array}{r}1.74 E-04 \\
1.85 E-03 \\
3.81 E-05 \\
1.35 E-04 \\
1.01 E-03 \\
1.29 E-04 \\
1.46 E-05 \\
<1.74 E-06 \\
2.35 E-05 \\
1.91 E-06 \\
\end{array}$ & $\begin{array}{r}1.91 \mathrm{E}-04 \\
1.50 \mathrm{E}-03 \\
1.91 \mathrm{E}-05 \\
1.22 \mathrm{E}-04 \\
1.06 \mathrm{E}-03 \\
1.14 \mathrm{E}-04 \\
1.26 \mathrm{E}-05 \\
4.46 \mathrm{E}-06 \\
1.62 \mathrm{E}-05 \\
<1.62 \mathrm{E}-06 \\
\end{array}$ & $\begin{array}{l}1.83 E-04 \\
1.68 E-03 \\
2.86 E-05 \\
1.29 E-04 \\
1.04 E-03 \\
1.22 E-04 \\
1.36 E-05 \\
3.10 E-06 \\
1.99 E-05 \\
1.77 E-06 \\
\end{array}$ \\
\hline \multicolumn{7}{|c|}{ Total Metals Emissions, Condensibles } \\
\hline $\begin{array}{l}\text { Arsenic, lb/hr } \\
\text { Lead, Ib/hr } \\
\text { Chromium, Ib/hr } \\
\text { Titanium, lb/hr } \\
\text { Zinc, Ib/hr } \\
\text { Barium, Ib/hr } \\
\text { Cadmium, Ib/hr } \\
\text { Copper, lb/hr } \\
\text { Nickel, Ib/hr } \\
\text { Mercury, lb/hr }\end{array}$ & $\mid \begin{array}{r}1.83 \mathrm{E}-05 \\
1.66 \mathrm{E}-05 \\
2.17 \mathrm{E}-06 \\
<1.77 \mathrm{E}-05 \\
2.00 \mathrm{E}-05 \\
<1.77 \mathrm{E}-05 \\
3.20 \mathrm{E}-06 \\
4.29 \mathrm{E}-06 \\
1.03 \mathrm{E}-05 \\
6.29 \mathrm{E}-06\end{array}$ & $\begin{array}{r}2.32 E-05 \\
1.16 E-05 \\
3.07 E-06 \\
<1.80 E-05 \\
9.28 E-05 \\
<1.80 E-05 \\
1.74 E-05 \\
4.41 E-06 \\
1.86 E-06 \\
1.04 E-04\end{array}$ & $\begin{array}{l}2.08 E-05 \\
1.41 E-05 \\
2.62 E-06 \\
1.79 E-05 \\
5.64 E-05 \\
1.79 E-05 \\
1.03 E-0.5 \\
4.35 E-06 \\
6.08 E-06 \\
5.51 E-05\end{array}$ & $\begin{aligned} & 1.01 E-05 \\
< & 3.48 E-06 \\
< & 1.74 E-06 \\
< & 1.74 E-05 \\
& 7.85 E-06 \\
< & 1.74 E-05 \\
< & 8.97 E-07 \\
& 1.91 E-06 \\
< & 1.74 E-06 \\
& 4.20 E-06\end{aligned}$ & $\begin{aligned} & 1.18 E-05 \\
& 2.52 E-06 \\
< & 1.26 E-06 \\
< & 1.26 E-05 \\
& 1.70 E-05 \\
< & 1.26 E-05 \\
< & 6.49 E-07 \\
< & 1.26 E-06 \\
< & 1.26 E-06 \\
& 3.49 E-06\end{aligned}$ & $\begin{array}{l}1.10 E-05 \\
3.00 E-06 \\
1.50 E-06 \\
1.50 E-05 \\
1.24 E-05 \\
1.50 E-05 \\
7.73 E-07 \\
1.59 E-06 \\
1.50 E-06 \\
3.85 E-06\end{array}$ \\
\hline \multicolumn{7}{|c|}{ Estimated Total Metals Emissions } \\
\hline $\begin{array}{l}\text { Arsenic, Ib/hr } \\
\text { Lead, lb/hr } \\
\text { Chromium, } \mathrm{lb} / \mathrm{hr} \\
\text { Titanium, } \mathrm{lb} / \mathrm{hr} \\
\text { Zinc, Ib/hr } \\
\text { Barium, Ib/hr } \\
\text { Cadmium, Ib/hr } \\
\text { Copper, Ib/hr } \\
\text { Nickel, Ib/hr } \\
\text { Mercury, lb/hr }\end{array}$ & \begin{tabular}{|l|}
$1.89 E-04$ \\
$4.51 E-04$ \\
$2.48 E-04$ \\
$3.83 E-05$ \\
$5.46 E-04$ \\
$3.66 E-05$ \\
$1.35 E-05$ \\
$6.12 E-06$ \\
$1.36 E-04$ \\
$7.55 E-06$
\end{tabular} & $\begin{array}{l}8.70 E-05 \\
1.63 E-04 \\
6.69 E-05 \\
4.12 E-05 \\
4.64 E-04 \\
4.58 E-05 \\
2.73 E-05 \\
8.35 E-06 \\
5.99 E-05 \\
1.08 E-04\end{array}$ & $\begin{array}{l}1.38 E-04 \\
3.07 E-04 \\
1.58 E-04 \\
3.98 E-0.5 \\
5.05 E-04 \\
4.12 E-0.5 \\
2.04 E-05 \\
7.24 E-06 \\
9.81 E-05 \\
5.77 E-05\end{array}$ & $\begin{array}{l}1.84 E-04 \\
1.85 E-03 \\
3.98 E-05 \\
1.52 E-04 \\
1.02 E-03 \\
1.46 E-04 \\
1.55 E-05 \\
3.65 E-06 \\
2.52 E-05 \\
6.11 E-06\end{array}$ & $\begin{array}{l}2.03 E-04 \\
1.50 E-03 \\
2.04 E-05 \\
1.35 E-04 \\
1.08 E-03 \\
1.27 E-04 \\
1.32 E-05 \\
5.72 E-06 \\
1.75 E-05 \\
5.11 E-06\end{array}$ & \begin{tabular}{|l}
$1.93 E-04$ \\
$1.68 E-03$ \\
$3.01 E-05$ \\
$1.44 E-04$ \\
$1.05 E-03$ \\
$1.37 E-04$ \\
$1.44 E-05$ \\
$4.69 E-06$ \\
$2.14 E-05$ \\
$5.61 E-06$
\end{tabular} \\
\hline
\end{tabular}


a range of $375^{\circ} \mathrm{F}$ between tests. Generally, all of the tests had much higher levels of oxygen compared to a commercial boiler, indicating high excess air.

\section{Pallets}

The combustion of the pallet wood was very similar to the demolition wood. The dry pallet wood burned hot and quickly, producing a comparatively small amount of fine light ash mixed with nails.

\section{Demolition Waste Wood}

Combustion of the demolition wood was performed with little operational difficultly. The wood burned hot and complete with moderate combustion air flow. The resulting ash was a combination of fine particles, ranging from bright white to black in color, mixed with sand, stone, and some loose metal.

\section{RESULTS}

The results of this program can be used to estimate fuel and ash quality of the different fuel blends. In the following sections, results from the analysis of each fuel type is discussed. The data from this program were compared to data from other waste wood test programs and literature.

\section{Ultimate/Proximate Analyses}

Table 3-2 summarizes the Ultimate/Proximate analyses for the fuel materials tested. Lower sulfur in demolition wood could indicate refusal to accept wood with sulfur-containing contaminant and/or better removal of such contaminants as tar paper or shingles.

\section{Laboratory Ash Fusion Temperatures}

Ash becomes soft and sticky and, as the temperature continues to rise, it becomes fluid. ASTM D1857 is the test method used to evaluate the fusibility of ashes. Table 3-3 summarizes the laboratory ash fusion temperatures for the waste fuels studied. The waste wood stream with higher levels of metal contaminants in the wood (demolition wood) had generally lower ash fusion temperatures.

\section{Metals Analyses}

The individual wood samples were analyzed for six metals (arsenic, chromium, lead, mercury, titanium and zinc). These metals are indicators of contaminants in waste woods which could raise environmental concerns. Due to their relatively high vapor pressure, arsenic and mercury analyses were performed on the noncombusted materials to avoid material losses associated with ashing. The analyses of other metals were performed after ashing the materials in the laboratory. Because the percent ash on a dry basis 
Table 3-2

Ultimate/Proximate Analysis of Waste Fuel Samples

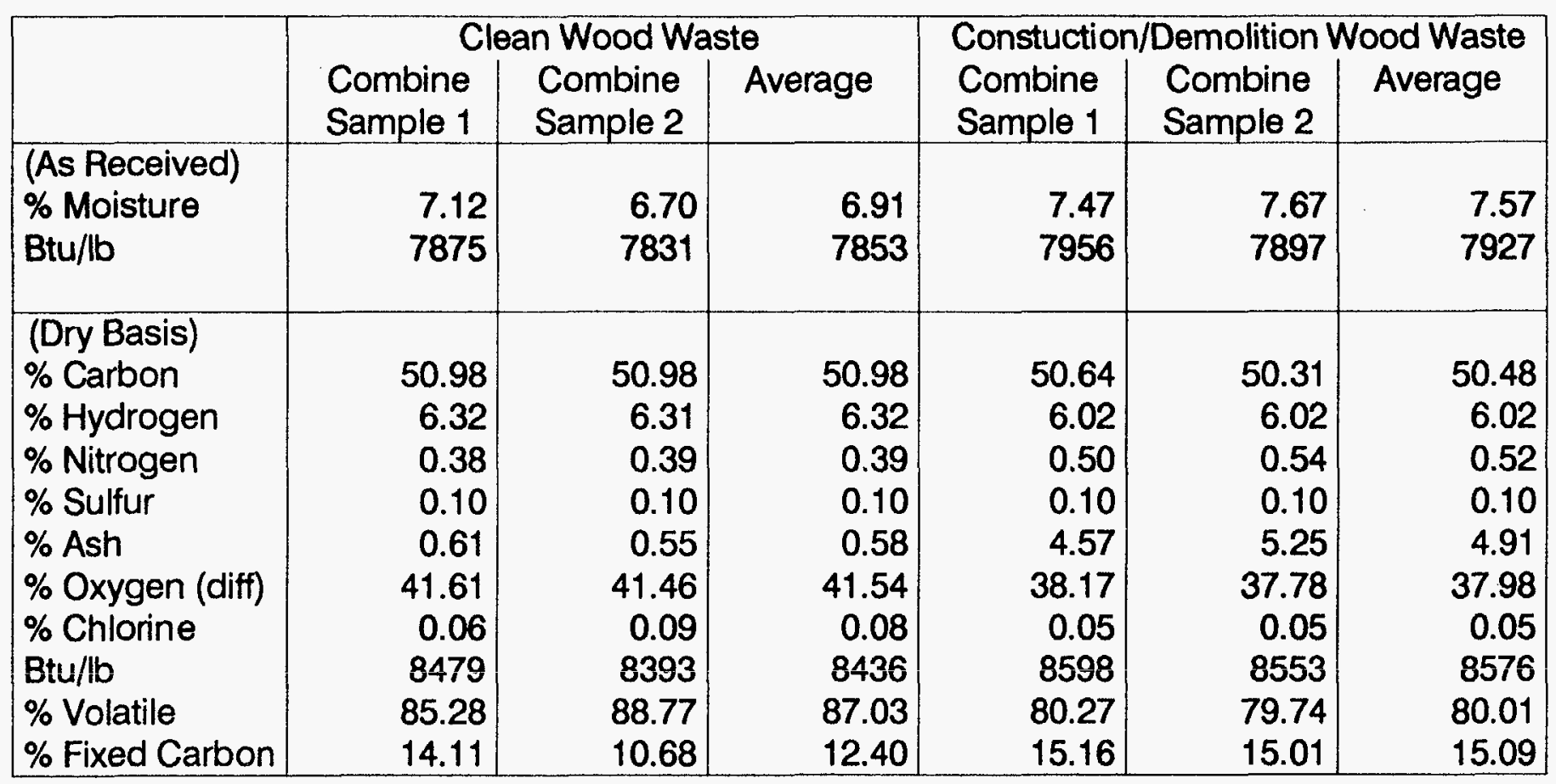


Table 3-3

Laboratory Ash Fusion Temperatures

Of Waste Fuel Samples

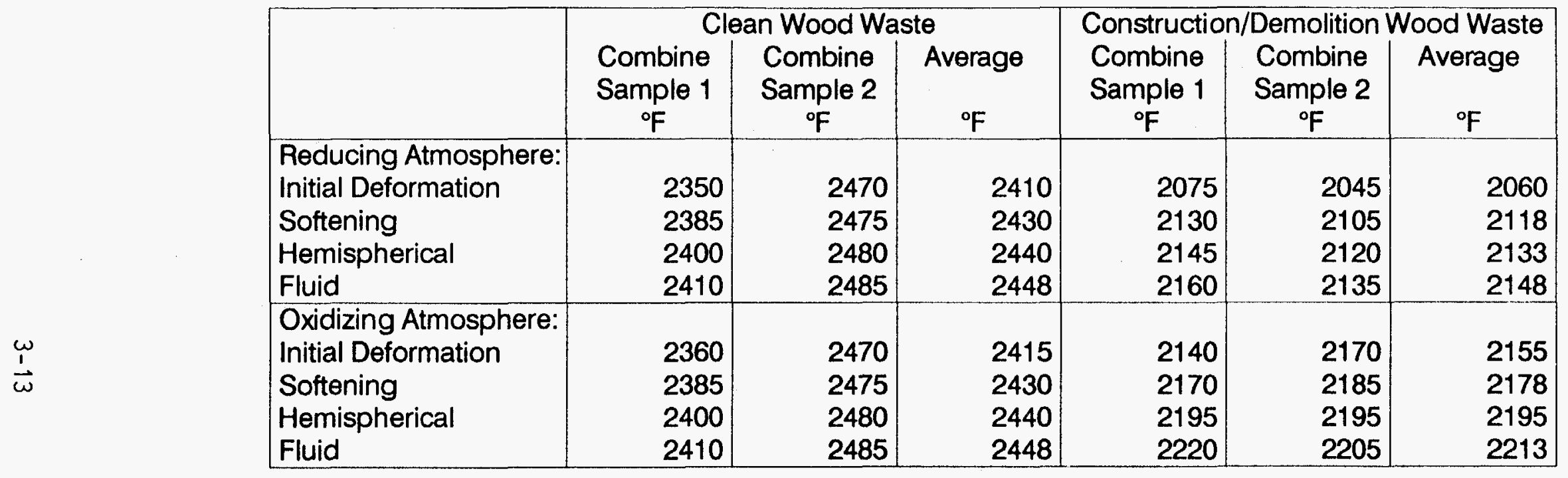


was determined for each of the samples, the data were available to calculate the concentration of metals in the ash. This calculation assumes all metal in the wood is converted into ash according to the calculation of metal in wood $\times 100 / \%$ ash $=$ metal in ash.

Tables 3-4 and 3-5 summarize the laboratory results obtained for each of the individual samples. Tables 3-6 and 3-7 are statistical summary tables for each individual fuel type. These tables report results both on a dry wood and dry ash basis.

As expected, the demolition wood samples overall had higher levels of metals on a dry wood basis compared to the clean fuel. Arsenic and chromium concentrations in the demolition wood are only marginally higher than in the clean wood, with some samples indicating levels lower than the clean wood. The levels of lead, mercury, titanium, and zinc in the demolition wood are significantly higher. Arsenic and chromium are typically associated with pressure-treated wood and it appears that at the time of sampling, the processing facility was doing a good job keeping these materials out of the processed wood stream. The other metals are used as pigments and fungicides in paints.

\section{Mineral analysis of ash}

The mineral analyses of the samples generated in the pilot plant were evaluated to determine possible ash disposal options and environmental benefits or hazards in combusting these fuels. The data on these analyses are summarized in Table 3-8.

The clean material had higher concentrations of most metal oxides tested, which is probably due to the low quantity of soil (silicon dioxide) with this fuel stream. Interestingly, the level of iron oxide in these samples was approximately $13 \%$ by weight compared to $5.8 \%$ for the other material. This could be the result of partial oxidation of nails in the pallet waste and the very small quantity of ash generated.

The demolition wood samples contained higher levels of aluminum and titanium metal oxides. Both of these compounds are found naturally in wood; however, the greater relative concentration of these compounds compared to those in clean wood may indicate the presence of non-wood components. These metals are, however, relatively common in soil and may be the result of higher dirt levels in the waste wood.

\section{Total Elemental Analysis in Ash Samples}

The primary concern in analyzing the ash samples is to determine the potential for leaching toxic metals. This should occur more readily in the finer fractions of ash with greater surface area. Therefore, each sample was sifted through a quarter-inch mesh screen and only the quarter-inch minus fractions of the 
Table 3-4

Clean Wood Incremental Analyses

Metals Concentrations In Waste Wood

\begin{tabular}{|l|r|r|r|r|r|}
\hline Sample \# & 94401 & 94402 & 94403 & 94404 & 94405 \\
\hline Total in wood (ppm): & \multicolumn{5}{|c|}{$\mid$} \\
\hline Arsenic & 3 & 20 & 20 & 15 & 25 \\
Chromium & 28 & 32 & 29 & 28 & 25 \\
Lead & 20 & 35 & 26 & 36 & 22 \\
Mercury & 0.07 & 0.13 & 0.08 & 0.09 & 0.11 \\
Titanium & 22 & 45 & 39 & 49 & 31 \\
Zinc & 22 & 27 & 12 & 24 & 21 \\
\%Ash, Dry Basis & 0.58 & 0.82 & 0.62 & 0.55 & 0.61 \\
\hline Total in ash (ppm), calculated from wood analysis: & & \\
\hline Arsenic & 517 & 2439 & 3226 & 2727 & 4098 \\
Chromium & 4828 & 3902 & 4677 & 5091 & 4098 \\
Lead & 3448 & 4268 & 4194 & 6545 & 3607 \\
Mercury (a) & 12 & 16 & 13 & 16 & 18 \\
Titanium & 3793 & 5488 & 6290 & 8909 & 5082 \\
Zinc & 3793 & 3293 & 1935 & 4364 & 3443 \\
\hline
\end{tabular}

(a) Since the vapor pressure of heated mercury is high, much of the mercury will not collect in ash. Therefore, these numbers are conservatively high.

Table 3-5

Construction/Demolition Wood Incremental Analyses Metals Concentrations In Waste Wood

\begin{tabular}{|l|r|r|r|r|r|}
\hline Sample \# & 94408 & 94409 & 94410 & 94411 & 94412 \\
\hline Total in wood (ppm): & \multicolumn{5}{|c|}{} \\
\hline Arsenic & 34 & 26 & 17 & 28 & 10 \\
Chromium & 41 & 45 & 201 & 36 & 20 \\
Lead & 125 & 159 & 251 & 124 & 143 \\
Mercury & 0.89 & 0.69 & 0.78 & 0.63 & 0.89 \\
Titanium & 290 & 302 & 616 & 331 & 403 \\
Zinc & 132 & 151 & 203 & 119 & 140 \\
\%Ash, Dry Basis & 3.61 & 2.65 & 7.24 & 3 & 4.2 \\
\hline Total in ash (ppm), calculated from wood analysis: & 981 & 235 & 933 & 238 \\
\hline Arsenic & 942 & 981 & 1200 & 476 \\
Chromium & 1136 & 1698 & 2776 & 4133 & 3405 \\
Lead & 3463 & 6000 & 3467 & 21 & 21 \\
Mercury (a) & 25 & 26 & 11 & 11033 & 9595 \\
Titanium & 8033 & 11396 & 8508 & 1103 \\
Zinc & 3657 & 5698 & 2804 & 3967 & 3333 \\
\hline
\end{tabular}

(a) Since the vapor pressure of heated mercury is high, much of the mercury will not collect in ash. Therefore, these numbers are conservatively high. 
Table 3-6

Summary Data of Clean Wood Analyses

Metals Concentrations In Waste Wood

\begin{tabular}{|c|c|c|c|c|c|c|}
\hline & $\begin{array}{c}\text { Number of } \\
\text { Samples }\end{array}$ & $\begin{array}{c}\text { Arithmetic } \\
\text { Average }\end{array}$ & $\begin{array}{l}\text { Standard } \\
\text { Deviation }\end{array}$ & $\begin{array}{l}\text { Minimum } \\
\text { Detected }\end{array}$ & $\begin{array}{l}\text { Maximum } \\
\text { Detected }\end{array}$ & Median \\
\hline \multicolumn{7}{|c|}{ Total in wood (ppm): } \\
\hline Arsenic & 5 & 16.6 & 8.4 & 3 & 25 & 20 \\
\hline Chromium & 5 & 28.4 & 2.5 & 25 & 32 & 28 \\
\hline Lead & 5 & 27.8 & 7.4 & 20 & 36 & 26 \\
\hline Mercury & 5 & 0.096 & 0.02 & 0.07 & 0.13 & 0.09 \\
\hline Titanium & 5 & 37.2 & 10.9 & 22 & 49 & 39 \\
\hline Zinc & 5 & 21.2 & 5.6 & 12 & 27 & 22 \\
\hline \multicolumn{7}{|c|}{ Total in ash (ppm), calculated from wood analysis: } \\
\hline Arsenic & 5 & 2602 & 1324 & 517 & 4098 & 2727 \\
\hline Chromium & 5 & 4519 & 501 & 3902 & 5091 & 4677 \\
\hline Lead & 5 & 4412 & 1245 & 3448 & 6545 & 4194 \\
\hline Mercury (a) & 5 & 15 & 2 & 12 & 18 & 16 \\
\hline Titanium & 5 & 5912 & 1903 & 3793 & 8909 & 5488 \\
\hline Zinc & 5 & 3366 & 899 & 1935 & 4364 & 3443 \\
\hline
\end{tabular}

(a) Since the vapor pressure of heated mercury is high, much of the mercury will not collect in ash. Therefore, these numbers are conservatively high.

Table 3-7

Summary Data of Construction/Demolition Wood Analyses Metals Concentrations In Waste Wood

\begin{tabular}{|c|c|c|c|c|c|c|}
\hline & $\begin{array}{l}\text { Number of } \\
\text { Samples }\end{array}$ & $\begin{array}{c}\text { Arithmetic } \\
\text { Average }\end{array}$ & $\begin{array}{l}\text { Standard } \\
\text { Deviation }\end{array}$ & $\begin{array}{l}\text { Minimum } \\
\text { Detected }\end{array}$ & $\begin{array}{l}\text { Maximum } \\
\text { Detected }\end{array}$ & Median \\
\hline \multicolumn{7}{|c|}{ Total in wood (ppm): } \\
\hline Arsenic & 5 & 23 & 9.5 & 10 & 34 & 26 \\
\hline Chromium & 5 & 68.6 & 74.6 & 20 & 201 & 41 \\
\hline Lead & 5 & 160.4 & 52.7 & 124 & 251 & 143 \\
\hline Mercury & 5 & 0.776 & 0.12 & 0.63 & 0.89 & 0.78 \\
\hline Titanium & 5 & 388.4 & 134.6 & 290 & 616 & 331 \\
\hline Zinc & 5 & 149 & 32.4 & 119 & 203 & 140 \\
\hline \multicolumn{7}{|c|}{ Total in ash (ppm), calculated from wood analysis: } \\
\hline Arsenic & 5 & 666 & 392 & 235 & 981 & 933 \\
\hline Chromium & 5 & 1457 & 856 & 476 & 2776 & 1200 \\
\hline Lead & 5 & 4094 & 1107 & 3405 & 6000 & 3467 \\
\hline Mercury (a) & 5 & 21 & 6 & 11 & 26 & 21 \\
\hline Titanium & 5 & 9713 & 1489 & 8033 & 11396 & 9595 \\
\hline Zinc & $\mathbf{5}$ & 3892 & 1098 & 2804 & 5698 & 3657 \\
\hline
\end{tabular}

(a) Since the vapor pressure of heated mercury is high, much of the mercury will not collect in ash. Therefore, these numbers are conservatively high. 
Table 3-8

Minerals In Ash Analysis of Ash

Generated in Pilot-Scale Combustion Facility

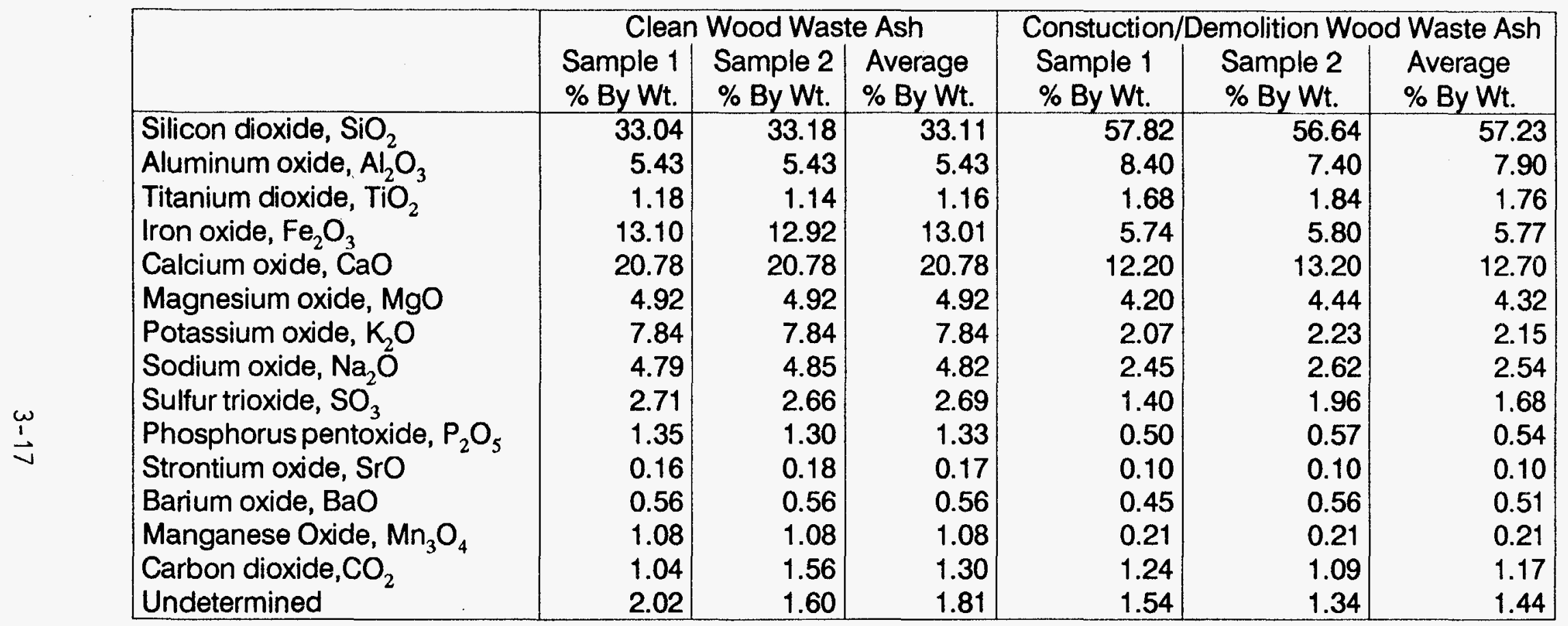


samples were analyzed. This size ranging removed rocks and metal pieces that would be difficult for the laboratory to process and removed most of the unburned wood splinters that fell through the combustion grate.

Tables 3-9 and 3-10 summarize the total metals analysis for 10 metals on samples of wood and ash. The wood samples represent mixtures of the incremental samples and are representative of the entire sample burned in the pilot plant. The ash samples are split samples of the ash generated in the pilot scale combustion unit.

With the exception of mercury, which volatilizes from the wood at combustion temperatures, the comparison between the ash metals concentrations estimated from the wood analyses and the analyses of the bottom ash generated in the pilot combustor shows fairly good agreement.

\section{Toxic Characteristic Leaching Procedure (TCLP)}

Table 3-11 summarizes the results of TCLP testing of the various ash samples. In both cases, the only metals detected in the leachate were arsenic, barium and chromium. The results of the demolition ash analyses were well within regulatory limits. Surprisingly, the results of the clean wood ash analyses were above the regulatory limit for arsenic and chromium. Returning to the results of the total metals analysis presented in Tables 3-6 through 3-10, it can be seen that the levels of arsenic and chromium in the wood fuel are similar between clean wood and demolition wood. However, on an ash basis and in the pilot-scale ash, the arsenic and chromium concentrations are much higher iu the clean wood ash. Although the clean wood may produce less overall ash than the demolition wood, the metals in the ash are more concentrated making the clean wood ash more toxic.

\section{Material Balance}

Material balances were performed with the test data collected during the pilot combustion tests. The purpose for conducting these balances was to be able to better evaluate the representativeness of the various measurement parameters in evaluating the quality of the wood combusted and the distribution of metal emissions within the different waste streams.

In conducting these material balances, a number of parameters and measurements were used. They include:

1. Fuel analyses and the quantity of fuel burned during the test period. As previously discussed, the fuel sample metal analyses were performed on small quantities of a heterogeneous material. The mean values from this sampling are probably representative of the materials combusted. However, many samples need to be collected and analyzed 
Table 3-9

Total Elemental Analysis in Clean Wood Waste Fuel and Ash Samples Generated in Pilot-Scale Combustion Facility

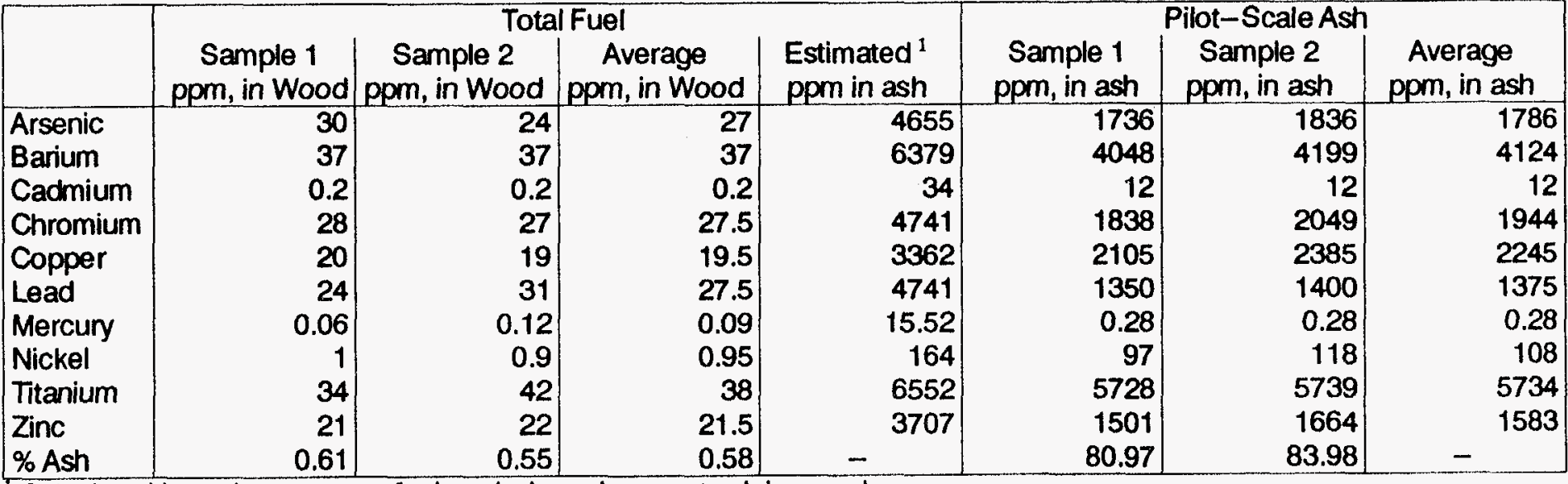

Calculated based on average fuel analysis and percent ash in wood.

Table 3-10

Total Elemental Analysis in Construction/Demolition Wood Waste Fuel and Ash Samples Generated in Pilot-Scale Combustion Facility

\begin{tabular}{|c|c|c|c|c|c|c|c|}
\hline & \multicolumn{4}{|c|}{ Total Fuel } & \multicolumn{3}{|c|}{ Pilot-Scale Ash } \\
\hline & $\begin{array}{c}\text { Sample } 1 \\
\text { ppm, in Wood }\end{array}$ & $\begin{array}{c}\text { Sample } 2 \\
\text { ppm, in Wood }\end{array}$ & $\begin{array}{c}\text { Average } \\
\text { ppm, in Wood }\end{array}$ & $\begin{array}{l}\text { Estimated }{ }^{1} \\
\text { ppm in ash }\end{array}$ & $\begin{array}{c}\text { Sample } 1 \\
\text { ppm, in ash }\end{array}$ & $\begin{array}{c}\text { Sample } 2 \\
\text { ppm, in ash }\end{array}$ & $\begin{array}{c}\text { Average } \\
\text { ppm, in ash }\end{array}$ \\
\hline Arsenic & 17 & 14 & 16 & 316 & 311 & 362 & 337 \\
\hline Barium & 228 & 227 & 228 & 4633 & 3592 & 4366 & 3979 \\
\hline Cadmium & 1.00 & 1.00 & 1.00 & 20 & 11 & 10 & 11 \\
\hline Chromium & 84 & 65 & 75 & 1517 & 280 & 342 & 311 \\
\hline Copper & 42 & 34 & 38 & 774 & 323 & 838 & 581 \\
\hline Lead & 193 & 172 & 183 & 3717 & 2395 & 3784 & 3090 \\
\hline Mercury & 0.31 & 0.65 & 0.48 & 9.78 & 0.06 & 0.06 & 0.06 \\
\hline Nickel & 29 & 23 & 26 & 530 & 54 & 52 & 53 \\
\hline Titanium & 438 & 461 & 450 & 9155 & 9045 & 9633 & 9339 \\
\hline Zinc & 181 & 155 & 168 & 3422 & 2276 & 2630 & 2453 \\
\hline$\%$ Ash & 4.57 & 5.25 & 5 & - & 89.8 & 87.33 & - \\
\hline
\end{tabular}

Calculated based on average fuel analysis and percent ash in wood. 
Table 3-11

Toxic Characteristic Leachate Procedure Analysis of Ash Generated in Pilot-Scale Combustion Facility

\begin{tabular}{|c|c|c|c|c|c|c|}
\hline & \multirow{2}{*}{$\begin{array}{l}\text { Minimum } \\
\text { Detection } \\
\text { Limit }\end{array}$} & \multirow{2}{*}{$\begin{array}{c}\text { Regulatory } \\
\text { Limits } \\
\mathrm{mg} / \mathrm{L}\end{array}$} & \multicolumn{2}{|c|}{ Clean Wood Waste Ash } & \multicolumn{2}{|c|}{$\begin{array}{l}\text { Constuction/Demolition } \\
\text { Wood Waste Ash }\end{array}$} \\
\hline & & & $\begin{array}{c}\text { Ash Sample } 1 \\
\mathrm{mg} / \mathrm{L}\end{array}$ & $\begin{array}{c}\text { Ash Sample } 2 \\
\mathrm{mg} / \mathrm{L}\end{array}$ & $\begin{array}{c}\text { Ash Sample } 1 \\
\mathrm{mg} / \mathrm{L}\end{array}$ & $\begin{array}{c}\text { Ash Sample } 2 \\
\mathrm{mg} / \mathrm{L}\end{array}$ \\
\hline Arsenic & 0.1 & 5 & 14 & 13 & 1.2 & 0.93 \\
\hline Barium & 0.01 & 100 & 4.4 & 4 & 1.7 & 1.3 \\
\hline Cadmium & 0.02 & 1 & ND & ND & ND & ND \\
\hline Chromium & 0.05 & 5 & 23 & 27 & 0.09 & 0.16 \\
\hline Lead & 0.1 & 5 & ND & ND & ND & ND \\
\hline Mercury & 0.002 & 0.2 & ND & ND & ND & ND \\
\hline Selenium & 0.1 & 1 & ND & ND & ND & ND \\
\hline Silver & 0.01 & 5 & ND & ND & $\mathrm{ND}$ & ND \\
\hline
\end{tabular}


to get a true average value for the metal content of this stream. In most cases, it is impractical and too costly to conduct the required sampling needed to obtain the real mean value. The quantity of fuel burned can be achieved with a high level of accuracy by weighing all of the material combusted.

2. The wood ash samples exhibit much less variability than the fuel they come from. As discussed, a small sample is still analyzed, but this material is more homogeneous than the wood it originates from since 30 - to 50 -fold more wood is used to generate an equivalent analytical quantity for the ash. The quantity of ash can be accurately measured and weighed. However, larger pieces of metals such as nails, slag, and banding can affect the analysis. As part of the test program, these materials were sieved out and removed from the samples. These materials were also sieved out and removed from the feed stock during its analysis. However, during the combustion process the surface of items such as nails represent an adhesion point for some of the metals and could slightly affect the metals content of the ash. Any slag formed on the bulk metal would also reduce those values of metals in the ash since these materials were not analyzed. However, this is probably a better indicator of what is in the particulate fraction.

3. The Method 5 particulate sampling and metals analysis is generally accurate to plus or minus $10 \%$. However, since the pilot unit was small and manually fed and controlled, temperature and gas volume were difficult to control and varied much more than in a fullscale system. Also due to the small size of the exhaust gas duct, the reliability of this information is limited. However, since particulate and condensible samples were collected simultaneously, the ratio of the amount of particulate metals to condensible metals provides a good indication of what can be expected in a full scale unit. That is, most of the metals will be in a particulate form and collectable in a good particulate control device. Also, the metals in the effluent gas stream will be quite small in size and constitute a very small fraction of the total bottom and fly ash metals.

Tables 3-12 and 3-13 summarize the results of mass balance calculations performed for each of the fuel tests based on wood, ash, and stack testing for ten selected metals. The metals entering the system were estimated by multiplying the concentration of each metal in wood, dry basis, times the total amount of dry wood feed over the length of each test. Metals could only leave the system through three routes: in bottom ash, in flyash, or as a vapor that was condensed to establish its concentration. Metals in the bottom ash were estimated based on the measured concentrations in the ash samples times the total amount of bottom ash collected for each run minus nails and rocks. Concentrations of metals in flyash were determined by analysis of the front-half (filter and probe rinse) of the Method 5 sampling train. Stack tests were used to determine particulate emissions, metal concentrations and flue gas flowrates. Metals in condensibles were determined from the back half of the sampling train. Flyash metal emissions were determined from these values and from the duration of the combustion tests. Closure of the material balance was determined by subtracting the amount of each metal leaving the system from what entered the system. The closer closure is to zero the closer these calculations are in balance. Positive closure values indicate that more metal was reported entering the system than was accounted for leaving the system, while negative values mean the opposite.

Generally the balances are fairly good considering the number of possible variances in the data. One possible variance is the assumption that the average of the lab samples truly represents the entire sample 
Table 3-12

Mass Balance of Clean Wood Waste Test Burn November 1994

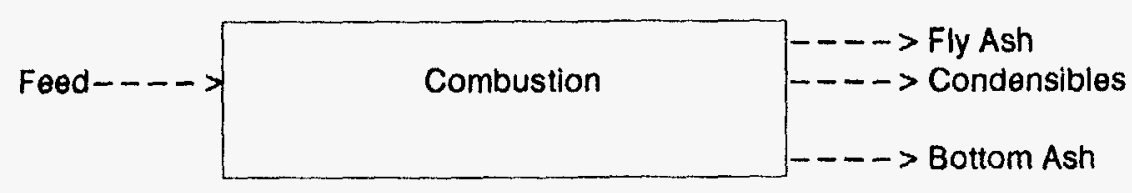

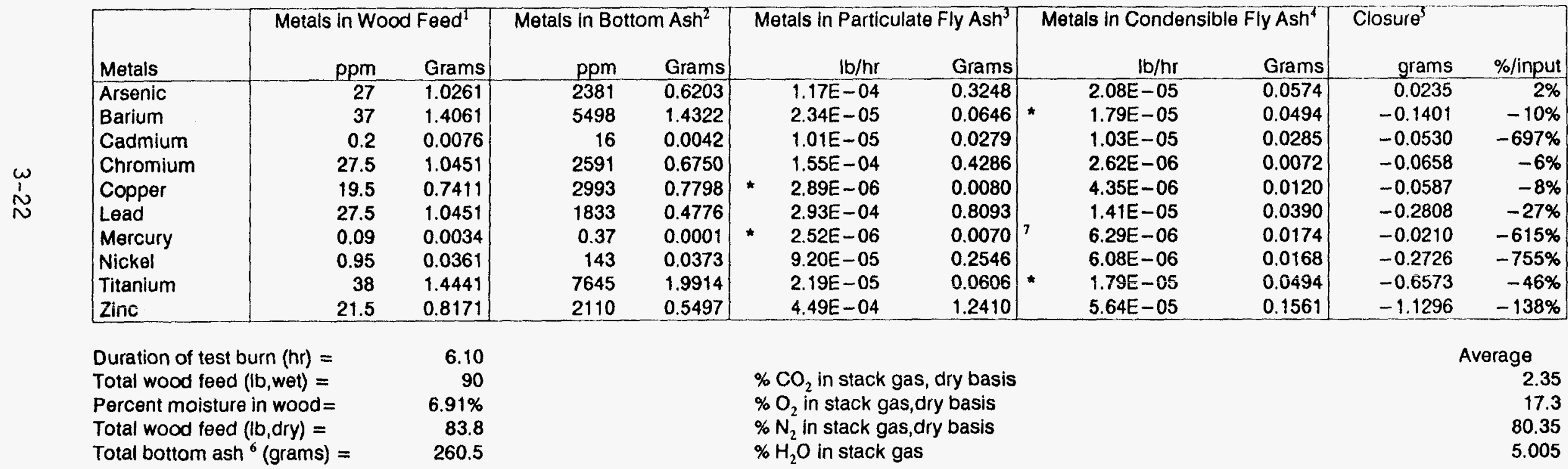

- Data so marked are based either partially or entirely on data that were below detection limits. Analyses

below detection were assumed at one-half the detection limit for calculation purposes.

${ }^{1}$ Based on average of two combined samples.

2 Based on average of two samples.

${ }^{3}$ Based on front half of EPA Mothod 5 air sampling train (filter and front half rinse).

${ }^{4}$ Based on back half of EPA Method 5 air sampling train (impingers).

5 The closer to zero this value is, the closer these calculations come into balance. Positive numbers indicate that more metal entered the system than was accounted for leaving the system. Negative numbers indicate the opposite.

6 Minus eighth inch nominal. Remainer consisted of nails and rock.

${ }^{7}$ Based only on the first run of the clean wood tests. ERL suspects that the second run, which indicated a rate of $1.04 E-04 \mathrm{lb} / \mathrm{hr}$ is erroneuos. 
Table 3-13

Mass Balance of Demolition Wood Test Burn November 1994

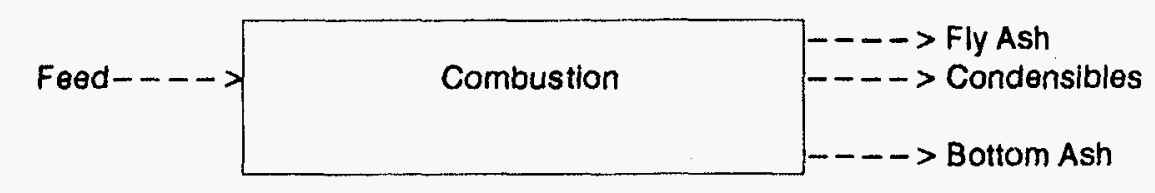

\begin{tabular}{|c|c|c|c|c|c|c|c|c|c|c|c|}
\hline \multirow[b]{2}{*}{ Metals } & \multicolumn{2}{|c|}{ Metals in Wood Foed ${ }^{1}$} & \multicolumn{2}{|c|}{ Metals in Bottom Ash ${ }^{2}$} & \multicolumn{3}{|c|}{ Metals in Particulate Fly Ash $^{3}$} & \multicolumn{2}{|c|}{ Metals in Condensible Fly Ash ${ }^{4}$} & \multicolumn{2}{|l|}{ Closure $e^{3}$} \\
\hline & ppm & Grams & ppm & Grams & & $\mathrm{lb} / \mathrm{hr}$ & Grams & $\mathrm{tb} / \mathrm{hr}$ & Grams & grams & $\% /$ input \\
\hline Arsenic & 16 & 0.6596 & 337 & 0.7260 & & $1.83 E-04$ & 0.4346 & $1.10 E-05$ & 0.0261 & -0.5271 & $-80 \%$ \\
\hline Barium & 228 & 9.6813 & 3979 & 8.5845 & & $1.22 E-04$ & 0.2893 & $1.50 E-05$ & 0.0357 & 0.7717 & $8 \%$ \\
\hline Cadmium & 1 & 0.0426 & 11 & 0.0227 & & $1.36 E-05$ & 0.0324 & $7.73 E-07$ & 0.0018 & -0.0143 & $-34 \%$ \\
\hline Chromium & 75 & 3.1704 & 311 & 0.6710 & & $2.86 E-05$ & 0.0681 & $1.50 E-06$ & 0.0036 & 2.4277 & $77 \%$ \\
\hline Copper & 38 & 1.6171 & 581 & 1.2524 & * & $3.10 E-06$ & 0.0074 & $1.59 E-06$ & 0.0038 & 0.3535 & $22 \%$ \\
\hline Lead & 183 & 7.7663 & 3090 & 6.6655 & & $1.68 E-03$ & 3.9888 & $3.00 E-06$ & 0.0071 & -2.8951 & $-37 \%$ \\
\hline Mercury & 0.48 & 0.0204 & 0.06 & 0.0001 & * & 1.77E-06 & 0.0042 & $3.85 E-06$ & 0.0092 & 0.0069 & $34 \%$ \\
\hline Nickel & 26 & 1.1064 & 53 & 0.1143 & & $1.99 E-05$ & 0.0473 & $1.50 E-06$ & 0.0036 & 0.9412 & $85 \%$ \\
\hline Titanium & 450 & 19.1285 & 9339 & 20.1485 & & $1.29 E-04$ & 0.3060 & $1.50 E-05$ & 0.0357 & -1.3617 & $-7 \%$ \\
\hline Zinc & 168 & 7.1493 & 2453 & 5.2922 & & $1.04 E-03$ & 2.4647 & $1.24 E-05$ & 0.0296 & -0.6373 & $-9 \%$ \\
\hline
\end{tabular}

Duration of test burn (hr) =

Total wood feed (lb,wet) =

Percent moisture in wood =

Total wood feed $(\mathrm{lb}$, dry $)=$

Total bottom ash ${ }^{6}$ (grams) $=$

5.25
101.5
$7.57 \%$
93.8
2157

\subsection{5}

1015

93.8

2157
$\% \mathrm{CO}_{2}$ in stack gas, dry basis

$\% \mathrm{O}_{2}$ in stack gas, dry basis

$\% \mathrm{~N}_{2}$ in stack gas, dry basis

$\% \mathrm{H}_{2} \mathrm{O}$ in stack gas
Average

4.45

15.9

79.65

4.66

* Data so marked are based either partially or entirely on data that were below detection limits. Analyses

below detection were assumed at one - half the detection limit for calculation purposes.

${ }^{1}$ Based on average of two samples.

${ }^{2}$ Based on average of two samples.

${ }^{3}$ Based on front half of EPA Method 5 air sampling train (filter and front half rinse).

${ }^{4}$ Based on back half of EPA Method 5 air sampling train (impingers).

5 The closer to zero this value is, the closer these calculations come into balance. Positive numbers indicate that more metal

entered the system than was accounted for leaving the system. Negative numbers indicate the opposite.

${ }^{6}$ Minus eighth inch nominal. Remainer consisted of nails and rock. 
burned. Even very small differences in the data make significant changes in the balance calculations, particularly in for mercury where all the values are very small. Values such as duration of test and total particulate emission rates are at best approximate since the fuel took time to ignite and burn properly at the beginning of the tests and then took a while to burn out at the end. Furthermore, it was difficult to accurately measure stack flow due to the small volume of flow and the small size of the duct work relative to the probe.

In the tests on clean wood, the balances for cadmium, mercury, nickel and zinc were poor, indicating significantly larger amounts of these metals leaving in the flyash than predicted from the fuel tests. During the demolition tests, the balances on these metals were much better, probably as a result of the higher concentrations of metal in the feed material.

Based on the information gathered during this test burn, the Contractor believes that testing of the bottom ash and fly ash is a more accurate means to determine long term fuel quality and that fuel testing, due to the high variability in the fuel, the number of samples that need to be analyzed, and the relatively low metals concentration, is not reliable to establish fuel quality unless many samples are collected and analyzed and a large standard deviation of the data is acceptable.

\section{Comparison With Other Wood Data}

It would be expected that the clean wood generated from pallets and boxes would be similar in metals composition to that of virgin wood, forest residuals, pallets and clean wood chips from other studies. Likewise, demolition wood from this study should be similar to demolition wood from other sources. Tables 3-14 and 3-15 compare the clean and demolition wood and ash from this study with data from several other sources of wood and ash data. It appears that the clean wood from this study contains generally higher levels of arsenic, chromium, and lead than other clean wood samples tested. This indicates that pressure treated wood containing chromium and arsenic, and painted wood containing lead may not have been completely removed from the clean fuel stream. Comparing the demolition wood indicates that this waste fuel is approximately equal to the average of other processors. 
Table 3-14

Summary of Average Metals in Wood Data (ppm)

\begin{tabular}{|c|c|c|c|c|c|c|}
\hline & $\begin{array}{l}\text { Combined } \\
\text { Clean Fuel From } \\
\text { This Study }\end{array}$ & Clean Wood & $\begin{array}{c}\text { Combined } \\
\text { Demolition Fuel } \\
\text { From This Study }\end{array}$ & $\begin{array}{c}\text { Normal } \\
\text { Construction/ } \\
\text { Demolition } \\
\end{array}$ & $\begin{array}{c}\text { Better } \\
\text { Construction/ } \\
\text { Demolition }^{3} \\
\end{array}$ & $\begin{array}{c}\text { Not Better } \\
\text { Construction/ } \\
\text { Demolition }\end{array}$ \\
\hline Arsenic & 27 & 1 & 16 & 36 & 18 & 70 \\
\hline Chromium & 28 & 3 & 75 & 40 & 29 & 63 \\
\hline Lead & 28 & 11 & 183 & 207 & 131 & 359 \\
\hline Titanium & 38 & 135 & 450 & 171 & 231 & 52 \\
\hline Zinc & 22 & 23 & 168 & 187 & 146 & 270 \\
\hline Barium & 37 & 73 & 228 & 197 & 186 & 211 \\
\hline Cadmium & 0.20 & 0.34 & 1.00 & 0.92 & 0.92 & 0.93 \\
\hline Copper & 20 & 4 & 38 & 93 & 34 & 172 \\
\hline Mercury & 0.09 & 0.07 & 0.48 & 0.11 & 0.12 & 0.09 \\
\hline Nickel & 1.0 & 3.1 & 26.0 & 13.2 & 16.8 & 8.5 \\
\hline
\end{tabular}

IIncludes clean wood chips, pallets, forest residuals, yard waste, bark chips, and virgin wood.

${ }^{2}$ Includes all available data on construction/demolition wood samples.

3includes only data on construction/demolition wood samples for facilities

known to follow better seperation and inspection techniques.

${ }^{4}$ Includes data from all sources not included in the better construction/demolition calculations.

Table 3-15

Summary of Average Metals in Ash Data (ppm)

\begin{tabular}{|c|c|c|c|c|c|c|}
\hline & $\begin{array}{l}\text { Combined } \\
\text { Clean Ash From } \\
\text { This Study }\end{array}$ & $\begin{array}{l}\text { Clean Wood } \\
\text { Combined Ash }\end{array}$ & $\begin{array}{c}\text { Combined } \\
\text { Demolition Ash } \\
\text { From This Study }\end{array}$ & $\begin{array}{c}\text { Normal } \\
\text { Construction/ } \\
\text { Demolition }{ }^{2} \\
\text { Combined Ash }\end{array}$ & $\begin{array}{c}\text { Better } \\
\text { Construction/ } \\
\text { Demolition }{ }^{3} \\
\text { Combined Ash }\end{array}$ & $\begin{array}{c}\text { Not Better } \\
\text { Construction/ } \\
\text { Demolition }{ }^{4} \\
\text { Combined Ash }\end{array}$ \\
\hline Arsenic & 1786 & 39 & 337 & 478 & 325 & 804 \\
\hline Chromium & 1944 & 89 & 311 & 611 & 507 & 769 \\
\hline Lead & 1375 & 323 & 3090 & 3734 & 3422 & 3687 \\
\hline Titanium & 5734 & 2292 & 9339 & 6392 & 8269 & 761 \\
\hline Zinc & 1583 & 812 & 2453 & 4031 & 4103 & 3508 \\
\hline Barium & 4124 & 1575 & 3979 & 3437 & 3456 & 3384 \\
\hline Cadmium & 12 & 9 & 11 & 15 & 15 & 11 \\
\hline Copper & 2245 & 400 & 581 & 1030 & 688 & 1591 \\
\hline Mercury & 0.28 & 1.14 & 0.06 & 2.04 & 2.35 & 0.73 \\
\hline Nickel & 108 & 67 & 53 & 198 & 237 & 71 \\
\hline
\end{tabular}

'Includes clean wood chips, pallets, forest residuals, yard waste, bark chips, and virgin wood.

Includes all available data on construction/demolition ash samples.

${ }^{3}$ Includes only data on construction/demolition ash samples for facilities

known to follow better seperation and inspection techniques.

4 Includes data from all sources not included in the better construction/demolition calculations. 


\section{INTRODUCTION}

Representative estimates of emissions from the Atlas project were required to prepare the permit application and to assess the potential air quality impacts from the facility. As a first step, a data and literature search was conducted for emissions information from similar gasification/boiler facilities. This search included: using the on-line database system DIALOG which has access to nearly 400 databases covering a broad scope of disciplines; the Contractor's own extensive in-house wood combustion emissions and wood composition databases; a review of the USEPA BACT/LAER Clearinghouse; and contacts with vendors of gasification systems, and funders of biomass and coal gasification research.

Where possible, the Contractor endeavored to use actual emissions test data from other similar facilities to estimate emissions from the Bio-Energy facility. However, biomass gasification in combination with a packaged steam boiler is still an emerging technology and limited data on emissions from commercial or research facilities are publicly available. Therefore, for combustion pollutants such as $\mathrm{NO}_{x}, \mathrm{CO}$, and $\mathrm{HC}$, the Contractor relied on estimates of expected emission rates supplied by the proposed bumer manufacturer. For other pollutants that are more a function of fuel composition than combustor design (e.g., sulfur dioxide), emissions were conservatively estimated based on waste wood composition and assumptions about the formation mechanisms. Particulate matter ( $P M$ ) emissions were obtained from the proposed manufacturer's budgetary proposal and based on anticipated outlet emissions after the baghouse.

Although noncriteria pollutant emissions data have been identified for solid wood combustion sources, no relevant data have been located for wood gas boilers. Therefore, this section discusses in theory how these pollutants may be emitted and attempts to place some bounds on maximum emissions. For example, material balance calculations were used to estimate metals emissions.

\section{EMISSIONS DATA FROM GASIFIER/BOILERS}

Emissions test data most applicable to the proposed Atlas Bio-Energy project were obtained from compliance test reports for similar wood gasification facilities in Oregon (Catalyst North Powder) ${ }^{1}$ and in California (State Central Heating Plant) ${ }^{2}$. Both gasification facilities were supplied by JWP Energy Products, Inc. (EPI), the same supplier of the gasifier for the proposed Bio-Energy project. Based on information supplied by EPI and contained in the test reports, the Catalyst North Powder, Oregon project used the identical gasifier (model no. FBG-100) as that proposed for the Bio-Energy project; the State Central Heating Plant gasifier is a smaller system (model FBG-75). 
The only significant differences from an emissions standpoint between the proposed project and the two other EPI gasification facilities are the burner design and the type of particulate control equipment. The equipment configuration at the Catalyst North Powder plant included a gasifier, boiler, multiclone, rotary drier, and low energy wet scrubber. The rotary dryer used exhaust from the boiler as the heat source. This additional equipment which is not part of the proposed Atlas Bio-Energy plant is not believed to affect emissions of $\mathrm{CO}, \mathrm{NO}_{\mathrm{x}}$ or hydrocarbons from the process if a standard (not low- $\mathrm{NO}_{\mathrm{x}}$ ) burner is used in the boiler to combust the gasified wood fuel (producer gas). The test results for the Catalyst North Powder facility are summarized in Table 4-1.

The particulate controls at the Catalyst North Powder facility consisted of a cyclone and a low-energy wet scrubber system instead of the high efficiency baghouse that will be used for the Atlas Bio-Energy facility. The proposed baghouse for the Atlas Bio-Energy facility will result in significantly lower particulate emissions. The type of wet scrubber system used at Catalyst North Powder will not significantly affect emissions of $\mathrm{CO}, \mathrm{NO}_{\mathrm{x}}$ or hydrocarbons.

The only other EPI gasifier/boiler facility from which data were obtained was the State Central Heating Plant in Sacramento, CA. The configuration of this plant, very similar to the proposed Bio-Energy plant, consisted of a gasifier, cyclone, boiler and multicyclone. Again, the multicyclone is not as efficient a particulate control device as the proposed baghouse for the Atlas project. However, the $\mathrm{CO}, \mathrm{NO}_{\mathbf{x}}$, and $\mathrm{HC}$ emissions are believed to represent standard producer gas combustion. The test results for the State Central Heating Plant facility are summarized in Table 4-2.

Another source of emissions data from a wood fueled gasifier was a demonstration program conducted by the Southern California Edison Company at the Highgrove Generating Station near Riverside, CA. ${ }^{3}$ The test program consisted of a downdraft gasifier that converted industrial wood waste and utility line cleared trimmings into low BTU gas. The gas was piped to a $44 \mathrm{MW}$ gas boiler or combusted without auxiliary fuel in a test flare. Emissions data obtained from both the steam boiler and the test flare included particulate, $\mathrm{NO}_{x}, \mathrm{SO}_{x}, \mathrm{HC}$, and PAH. The data are summarized in Table 4-3.

Only two other sources of emissions test data for wood gasification facilities were located from the data search; however, these sources were not deemed to be representative of the fluidized bed gasifier for the proposed project. One source of emissions data for particulate, $\mathrm{NO}_{\mathrm{x}}, \mathrm{CO}, \mathrm{HC}$, and formaldehyde was a 135 MMBTU/hr fuel cell type wood gasifier supplying three dryers in a oriented strand board (OSB) manufacturing process at the Potlatch Corporation plant in Bemidji, Minnesota. ${ }^{4}$ The emissions test data were not deemed to be representative because the gasifier was not a fluidized bed design and the fuel consisted of hardwood bark and dry waste generated in the OSB manufacturing process. Since phenol formaldehyde resins are used in the OSB manufacturing process, the formaldehyde emissions measured may have originated both from the gasification of waste OSB and the drying process. 


\section{Table 4-1 \\ Catalyst North Powder, Oregon Emissions and Plant Data Summary}

The plant is a $5 \mathrm{MW}$ boiler coupled to a fluidized bed gasifier fueled with planer shavings, sawdust and bark. The boiler emissions are controlled by a multicyclone and an entrained water separation scrubber.

\begin{tabular}{|l|r|r|l|}
\hline & $\begin{array}{c}\text { Average of } \\
1988 \text { Testing }\end{array}$ & $\begin{array}{c}\text { Average of } \\
1989 \text { Testing }\end{array}$ & \multicolumn{1}{|c|}{ Units } \\
\hline Number of tests & 2 & 3 & - \\
Stack Air Flowrate & 20770 & 23020 & $\mathrm{scfm}$ \\
Stack Air Flowrate & 16367 & 18301 & $\mathrm{dscfm}$ \\
Stack Temperature & 143 & 141 & ${ }^{\circ} \mathrm{F}$ \\
$\%$ Moisture volume basis & 21.2 & 20.5 & $\%$ \\
$\mathrm{CO} 2$ & 13.25 & 11.93 & $\%$; calculated \\
\hline Particulate & 0.0521 & 0.085 & $\mathrm{gr} / \mathrm{dscf}$ \\
Particulate Corr. to 12\% CO & 0.0472 & 0.0855 & $\mathrm{gr} / \mathrm{dscf}$ \\
\hline NOx & 17.2 & 21.3 & $\mathrm{lb} / \mathrm{hr}$ \\
NOx Corr. to $12 \% \mathrm{CO}_{2}$ & 254150 & 312517 & $\mathrm{ug} / \mathrm{dscm}$ \\
NOx Corr. to $12 \% \mathrm{CO}_{2}$ & 132.9 & 163.4 & $\mathrm{ppm}$ \\
\hline $\mathrm{CO}$ & 16.5 & 15.2 & $\mathrm{lb} / \mathrm{hr}$ \\
$\mathrm{CO}$ Corr. to $12 \% \mathrm{CO}_{2}$ & 243806 & 223017 & $\mathrm{ug} / \mathrm{dscm}$ \\
$\mathrm{CO}$ Corr. to $12 \% \mathrm{CO}_{2}$ & 209.4 & 191.5 & $\mathrm{ppm}$ \\
\hline $\mathrm{HC}$ HC Corr. to $12 \% \mathrm{CO}_{2}$ & 11821 & - & $\mathrm{lb} / \mathrm{hr}$ \\
$\mathrm{HC}$ Corr. to $12 \% \mathrm{CO}_{2}$ & 17.8 & - & $\mathrm{ug} / \mathrm{dscm}$ \\
\hline
\end{tabular}




\begin{tabular}{|c|c|c|}
\hline \multicolumn{3}{|c|}{$\begin{array}{c}\text { Table 4-2 } \\
\text { Emission Test Results } \\
\text { Biomass Woodchips } \\
\text { State Central Heating Plant }\end{array}$} \\
\hline & $\begin{array}{c}\text { Test No. } 1 \\
12 / 16 / 82 \\
(1008-1109)\end{array}$ & $\begin{array}{c}\text { Test No. } 2 \\
1 / 27 / 83 \\
(1202-1305)\end{array}$ \\
\hline Particulate Matter (grs/SDCF) & 0.06 & 0.07 \\
\hline $\begin{array}{l}\text { Particulate Matter (grs/SDCF corrected } \\
\text { to } 12 \% \mathrm{CO}_{2} \text { ) }\end{array}$ & 0.07 & 0.065 \\
\hline Particulate Matter Emission Rate (lbs/hr) & 5.9 & 5.3 \\
\hline Steam Output (lbs/hr) & 45,000 & 40,000 \\
\hline $\mathrm{NO}_{\mathrm{x}}(\mathrm{ppm})$ & 57 & 59 \\
\hline $\mathrm{SO}_{2}(\mathrm{ppm})$ & 6 & 4 \\
\hline THC as Propane (ppm) & 28 & 43 \\
\hline $\mathrm{CO}_{2}(\%)$ & 9.8 & 13.0 \\
\hline $\mathrm{O}_{2}(\%)$ & 9.7 & 6.6 \\
\hline $\mathrm{CO}(\mathrm{ppm})$ & 430 & 285 \\
\hline Stack Gas Flowrate (SDCFM) & 12,400 & 8,700 \\
\hline Stack Gas Velocity $(\mathrm{ft} / \mathrm{sec})$ & 39.2 & 26.2 \\
\hline $\begin{array}{l}\text { Particulate Matter Catch } \\
\text { Filter Catch, mg } \\
\text { Rinse before Filter, mg } \\
\text { Rinse after Filter, mg } \\
\text { Aqueous Condensate, mg }\end{array}$ & $\begin{array}{c}60.9 \\
23.0 \\
8.1 \\
6.8 \\
\end{array}$ & $\begin{array}{c}32.3 \\
4.7 \\
48.2 \\
5.9\end{array}$ \\
\hline Water Vapor in Stack Gases (\%) & 14 & 14 \\
\hline Fuel for Gasifier & Pine Wood Chips & Pine Wood Chips \\
\hline
\end{tabular}




\begin{tabular}{|c|c|c|c|}
\hline \multicolumn{4}{|c|}{$\begin{array}{c}\text { Table 4-3 } \\
\text { Highgrove Wood Gas } \\
\text { Emissions Summary - Flare and Boiler }\end{array}$} \\
\hline \multirow[t]{2}{*}{ Species } & \multirow{2}{*}{$\begin{array}{c}\text { Flare } \\
\text { (100\% woodgas) }\end{array}$} & \multicolumn{2}{|c|}{ Utility Boiler - $15 \mathrm{MW}$} \\
\hline & & $7 \%$ woodgas & $13 \%$ woodgas \\
\hline $\begin{array}{l}\mathrm{NO}_{\mathrm{x}} \mathrm{ppm} \\
\mathrm{ppm} @ 3 \% \mathrm{O}_{2} \\
\mathrm{lb} / \mathrm{hr}\end{array}$ & $\begin{array}{c}47 \\
76 \\
0.62\end{array}$ & $\begin{array}{l}83 \\
99 \\
36\end{array}$ & $\begin{array}{c}59 \\
105 \\
22\end{array}$ \\
\hline $\begin{array}{l}\mathrm{CO} \mathrm{ppm} \\
\text { ppm @3\% } \\
\mathrm{lb} / \mathrm{hr}\end{array}$ & $\begin{array}{c}15-88 \\
33-133 \\
0.2-0.66\end{array}$ & $\begin{array}{l}19 \\
23 \\
4.9\end{array}$ & $\begin{array}{c}9 \\
16 \\
2.0\end{array}$ \\
\hline 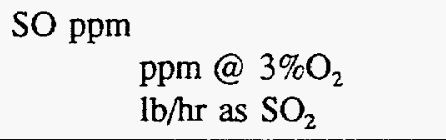 & $\begin{array}{c}6.1 \\
9.6 \\
0.12\end{array}$ & $\begin{array}{l}1.4 \\
2.3 \\
0.85\end{array}$ & $\begin{array}{l}-- \\
-- \\
-\end{array}$ \\
\hline $\begin{array}{l}\text { Solid Particulate** } \\
\text { gr/dscf @ } 12 \% \mathrm{CO}_{2} \\
\text { lb/hr }\end{array}$ & $\begin{array}{c}0.0088 \\
0.13\end{array}$ & $\begin{array}{c}0.0094 \\
2.59\end{array}$ & $\begin{array}{c}0.0084 \\
1.34\end{array}$ \\
\hline $\begin{array}{l}\text { Total Particulate } \\
\text { gr/dscf } @ 12 \% \mathrm{CO}_{2} \\
\text { lb/hr }\end{array}$ & $\begin{array}{l}0.010 \\
0.15\end{array}$ & $\begin{array}{l}0.0143 \\
3.92\end{array}$ & $\begin{array}{l}0.0112 \\
1.79\end{array}$ \\
\hline $\begin{array}{c}\mathrm{HC} \text { ppm @ } 3 \% \mathrm{O}_{2} \\
\mathrm{lb} / \mathrm{hr}\end{array}$ & $\begin{array}{l}115 \\
0.48\end{array}$ & $\begin{array}{l}173 \\
16.5\end{array}$ & $\begin{array}{l}-- \\
--\end{array}$ \\
\hline $\begin{array}{l}\text { Total PAH* } \\
\mu \mathrm{g} / \mathrm{dscm}\end{array}$ & 1.13 & 0.33 & -. \\
\hline $\mathrm{O}_{2} \%$ & 10.7 & 9.7 & 13.3 \\
\hline $\mathrm{CO}_{2} \%$ & 10.0 & 6.5 & 4.4 \\
\hline $\mathrm{H}_{2} \mathrm{O} \%$ & 9.5 & 11.2 & 4.0 \\
\hline Combustion Temp ${ }^{\circ} \mathrm{F}$ & $2100-2200$ & Not taken & \\
\hline
\end{tabular}

** Total particulate consists of solid particulate plus condensible particulate in accordance with SCAQMD definitions and procedures.

Woodgas flow approx. 800 SCFM

- PAH - Polycyclic Aromatic Hydrocarbons 
The other source of gasification emissions data was from the testing of an updraft gasification unit on different fuel mixtures at a plant in Hameenlinna, Finland. ${ }^{5}$ The fuel with the closest similarity to the proposed project consisted of 45 percent wood chips and 55 percent municipal solid waste. Due to the higher concentrations of sulfur, metals and other compounds in municipal solid waste compared to wood chips, these test data were not deemed to be representative.

\section{$\mathrm{NO}_{\mathrm{x}}, \mathrm{CO}$, AND HC EMISSIONS}

The Catalyst North Powder and State Central Heating Plant facilities are considered to be the most representative of the proposed Atlas Bio-Energy project since both are based on EPI's wood gasifier technology. However, as seen from review of the emissions data in Tables 4-1 and 4-2, $\mathrm{NO}_{\mathrm{x}}, \mathrm{CO}$ and $\mathrm{HC}$ emissions vary significantly between the two data sets and are likely more a function of the burner design in the boilers than the biomass gasifier design. Therefore, the approach to estimating emissions from the proposed project relied more on expected emission rates obtained from the manufacturer of the burners for the project than on emissions data from existing facilities.

The contractor supplied material balance calculations based on the fuel composition to Coen Company, Inc., the proposed bumer supplier, and requested a proposal and expected emissions rates of $\mathrm{NO}_{x}, \mathrm{CO}$, and $\mathrm{HC}$. When requesting expected emission data from Coen, the Contractor also specified emission rate criteria for $\mathrm{NO}_{\mathrm{x}}, \mathrm{HC}$, and $\mathrm{CO}$ that would be required to maintain facility emissions under the major source thresholds for ozone precursors in a severe nonattainment area (25 TPY) and CO in a moderate nonattainment area (50 TPY). The required emission rates for $\mathrm{NO}_{\mathrm{x}}$ and $\mathrm{HC}$ are approximately $0.05 \mathrm{lb} / \mathrm{MMBTU}$ to maintain annual potential emissions under $25 \mathrm{TPY}$ and $0.1 \mathrm{lb} / \mathrm{MMBtu}$ for CO to be less than 50 TPY. Coen responded with a proposal for a low-NO $\mathrm{N}_{\mathrm{x}}$ burner design with flue gas recirculation with expected emissions for both $\mathrm{NO}_{\mathrm{x}}$ and $\mathrm{HC}$ capable of meeting the $0.05 \mathrm{lb} / \mathrm{MMBTU}$ criteria but only meeting $0.2 \mathrm{lb} / \mathrm{MMBtu}$ for CO. Therefore, with a new Coen low-NO $\mathrm{N}_{\mathrm{x}}$ burner, add-on flue gas control for $\mathrm{NO}_{\mathrm{x}}$ will not be needed to maintain $\mathrm{NO}_{\mathrm{x}}$ and $\mathrm{HC}$ emissions less than $25 \mathrm{TPY}$. However, for $\mathrm{CO}$, in order to avoid applicability of the nonattainment regulations and add-on controls, a dispersion modeling analysis was performed to demonstrate insignificant ambient $\mathrm{CO}$ impacts. The expected emission rates for $\mathrm{NO}_{x}, \mathrm{CO}$, and $\mathrm{HC}$ are summarized in Table 4-4.

\section{PARTICULATE EMISSIONS}

As previously discussed, the Catalyst North Powder facility used a low-energy wet scrubber system in combination with cyclones for particulate control and the State Central Heating Plant used a multicyclone; the proposed Atlas Bio-Energy plant will use a high efficiency baghouse capable of achieving much better particulate control. Although no test data were located for a gasification system equipped with a baghouse, 
Table 4-4

COEN Company, Inc. Low-NO ${ }_{x}$ Burner

Expected Emissions for $\mathrm{NO}_{x}, \mathrm{CO}$ and $\mathrm{HC}$ for

Atlas Bio-Energy Project

\begin{tabular}{|l|c|c|c|}
\hline & lb/MMBtu & $\mathrm{lb} / \mathrm{hr}^{3}$ & $\mathrm{TPY}^{2}$ \\
\hline $\mathrm{NO}_{\mathrm{x}}{ }^{3}$ & 0.05 & 5.41 & 23.67 \\
\hline $\mathrm{HC}^{3}$ & 0.015 & 1.62 & 7.10 \\
\hline $\mathrm{CO}^{3}$ & 0.20 & 21.62 & 94.70 \\
\hline
\end{tabular}

1 based on maximum 108.1 MMBtu/hr heat input rate

2 based on $8,760 \mathrm{hr} / \mathrm{yr}$

3 based on Coen (burner) emission guarantee 
the Contractor believes that particulate emissions from a fluidized combustor would be directly applicable. Table 4-5 summarizes particulate emissions data from fluidized combustors equipped with baghouses. The Contractor also reviewed the USEPA's RACT/BACT/LAER Clearinghouse Information System (BLIS) for information on recent Best Available Control Technology (BACT) determinations for fluidized bed combustor particulate emissions. This information is also summarized in Table 4-5. Based on a review of the data from six fluid bed combustors with a combination of mechanical collectors and baghouses (one also has an ESP), permit limits range from 0.02 to $0.045 \mathrm{lb} / \mathrm{MMBtu}$, and tested levels range from 0.006 to $0.025 \mathrm{lb} / \mathrm{MMBtu}$. From this review, it is evident that a cyclone in combination with a baghouse is considered BACT and that an appropriate particulate permit level is $0.04 \mathrm{lb} / \mathrm{MMBtu}$.

\section{$\mathrm{SO}_{2}$ AND HCL EMISSIONS}

$\mathrm{SO}_{2}$ and $\mathrm{HCl}$ are emitted in low quantities from typical wood-fired boilers due to the low levels of $\mathrm{S}$ and $\mathrm{Cl}$ in the wood fuel. Typically, much less $\mathrm{SO}_{2}$ and $\mathrm{HCl}$ is formed than is predicted from straight mass balance calculations because the $\mathrm{S}$ and $\mathrm{Cl}$ react with the natural alkalinity in wood and are tied up in the ash. The only relevant data located on $\mathrm{SO}_{2}$ emissions for a wood gasifier followed by a steam boiler were from the EPI gasifier based installation at the State Central Heating Plant in Sacramento ${ }^{2}$ and the Southern Califomia Edison Company's demonstrations program ${ }^{3}$. For the State Central Heating Plant test, two data points ranged from 4 to $6 \mathrm{ppm} \mathrm{SO}_{2}$ (see Table 4-2) while gasifying clean pine wood chips. For the Southern California Edison Company's program, two data points were found, one representative of 100 percent wood gas combusted in a test flare and the other from 7 percent wood gas combusted with natural gas in a utility boiler producing $15 \mathrm{MW}$. The emissions, summarized in Table 4-3 were $9.6 \mathrm{ppm}$ (corrected to $3 \% \mathrm{O}_{2}$ ) in the 100 percent wood gas flare exhaust and $2.3 \mathrm{ppm}$ (corrected to $3 \% \mathrm{O}_{2}$ ) from the boiler firing 7 percent wood gas. When converted to units of $\mathrm{lb} / \mathrm{MMBTU}$, the $\mathrm{SO}_{2}$ emissions for the $100 \%$ wood gas combustion from both data sets are less than approximately $0.02 \mathrm{lb} / \mathrm{MMBTU}$. This $\mathrm{SO}_{2}$ emission factor is typical of the combustion of clean wood, which typically has a wood sulfur content ranging from less than 0.01 to 0.05 dry weight percent; the actual sulfur content of the wood fuel for this test is unknown.

Since the sulfur content of clean wood can vary by an order of magnitude, the $\mathrm{SO}_{2}$ emissions from the Atlas project were conservatively estimated by assuming that the maximum sulfur content of the wood fuel to be gasified would be five times higher than the wood gasified during the two wood gasification emissions test programs. Accordingly, the estimated maximum $\mathrm{SO}_{2}$ emission rate is $0.1 \mathrm{lb} / \mathrm{MMBTU}$.

It should be noted that it is not straightforward to estimate $\mathrm{SO}_{2}$ emissions directly by mass balance from wood combustion processes. Based on published and unpublished data that the Contractor has reviewed, there is evidence that sulfur reacts with the natural alkalinity (calcium content) in wood and is retained in the ash, rather than emitted as $\mathrm{SO}_{2}{ }^{6.7}$ The Contractor has seen anywhere from 30 to 95 percent retention 
Table 4-5: Particulate Emissions from Fluidized Bed Combustors with Baghouses.

\begin{tabular}{|c|c|c|c|c|c|c|c|c|c|c|}
\hline \multirow[t]{2}{*}{ Plant Name } & \multirow[t]{2}{*}{ State } & \multirow[t]{2}{*}{ MMBtu/hr } & \multirow[t]{2}{*}{ Fuel } & \multirow{2}{*}{$\begin{array}{c}\text { Particulate } \\
\text { Controls }\end{array}$} & \multicolumn{6}{|c|}{ Other Emission Particulate Emissions } \\
\hline & & & & & Controls & $\begin{array}{l}\text { Permitted } \\
\text { Lb/MMBtu }\end{array}$ & $\begin{array}{c}\text { Tested } \\
\text { Lb/MMBtu }\end{array}$ & $\begin{array}{c}\text { Permitted } \\
\mathrm{Lb} / \mathrm{hr}\end{array}$ & $\begin{array}{c}\text { Tested } \\
\text { Lb/hr }\end{array}$ & $\begin{array}{l}\text { Tested } \\
\text { gr/dscf }\end{array}$ \\
\hline Mendota Biomass Powe & $\overline{\mathrm{CA}}$ & $\overline{418}$ & SILVBM & MCFF & SNCACC SI & 0.020 & 0.011 & 8.36 & 4.74 & 0.006 \\
\hline Madera Capco & CA & 400 & BM & MC FF & SNCR CC SI & 0.025 & & 10.00 & & \\
\hline Energy Factors Feather & CA & 247 & & MC ESP FF & CC & 0.101 & 0.025 & 24.83 & 6.06 & 0.011 \\
\hline Chowchilla II & CA & 191 & BM & MC FF & SNCR CC SI & 0.037 & & 7.07 & & \\
\hline El Nido & CA & 152 & SILV BM & MCFF & SNCR CC & 0.037 & & 5.62 & & \\
\hline Delano Energy Compan & CA & & SILV BM & MC FF & SNCR SC SI & 0.045 & 0.006 & & & 0.003 \\
\hline Average & & 282 & & & & 0.044 & 0.014 & 11.176 & 5.40 & 0.006 \\
\hline
\end{tabular}

Fuel Types:

SILV = Silvicultural

$\mathrm{BM}=$ Biomass
Particulate Controls:

$M C=$ Mechanical Collector

$\mathrm{ESP}=$ Electrostatic Precipitator

FF $=$ Fabric Filter Baghouse
Emission Controls:

SNCR = Selective Non-Catalytic Reduction

$\mathrm{CC}=$ Combustion Controls

$S C=$ Staged Combustion

$\mathrm{SI}=$ Sorbant/limestone Injection 
of sulfur in ash in wood combustion. Although similar information has not been located on wood gasification, information regarding the behavior of sulfur compounds in coal gasifiers is useful to predict that a similar phenomenon will occur.

Based on published articles and discussions with gasifier manufacturers and researchers knowledgeable in the field, essentially all of the sulfur in coal will form hydrogen sulfide $\left(\mathrm{H}_{2} \mathrm{~S}\right)$ and carbonyl sulfide (COS) in the gas under reduced oxygen conditions. ${ }^{8}$ (When this gas is combusted in a burner with excess air, all of the sulfur in the reduced sulfur compounds will be oxidized and form $\mathrm{SO}_{2}$.) Since coal does not naturally contain the calcium that wood does, there is little retention of sulfur in the ash in the coal gasifier. An extensive amount of research has been conducted on sulfur cleanup processes for coal gasifiers, some involving the injection of calcium-based sorbents into the gasifier to react with and retain the sulfur in the ash. A number of technical articles indicate that sulfur retentions of 90 percent are easily obtained by injecting limestone or dolomite into the fluidized bed to form calcium sulfide. The calcium sulfide is subsequently oxidized to calcium sulfate in the ash discharge section of the gasifier prior to landfill disposal of the ash. Based on a review of this information, a maximum $\mathrm{SO}_{2}$ emission rate of $0.1 \mathrm{lb} / \mathrm{MMBTU}$ is considered to be conservatively high.

Very little data are available on $\mathrm{HCl}$ emissions from wood-fired boilers and none has been located for wood gasifiers. However, due to the higher reactivity of $\mathrm{Cl}$ compared to $\mathrm{S}$, the $\mathrm{Cl}$ would be expected to react at least as effectively as $\mathrm{S}$ with the alkalinity in wood; probably more than $90 \%$ would remain in the ash. Therefore, $\mathrm{HCl}$ emissions from wood combustion and gasification will likely be insignificant (a few ppm).

\section{NONCRITERIA POLLUTANT EMISSIONS}

Other emissions typically associated with wood combustion includle trace metals, PAHs, and volatile organic compounds regulated as air toxics. Unfortunately, very limited data has been located representative of wood gasifiers with steam boilers.

PAH emissions data were taken during the Southern California Edison Co. demonstration program while firing a combination of natural gas and wood gas in a boiler and while firing $100 \%$ wood gas in a flare. Total and individual PAH data are summarized in Tables 4-6 and 4-7 for these two test conditions. These indicate fairly low values that are not high relative to wood combustion.

No metals emissions data were located representative of wood gasification. However, some information was found on the partitioning behavior of metals during pyrolysis of sewage sludge. ' A laboratory-scale study performed by the Swiss Federal Institute of Technology indicates that partitioning is a function of the specific metal vapor pressures and the pyrolysis temperature. $\mathrm{Cr}, \mathrm{Ni}, \mathrm{Cu}, \mathrm{Zn}$ and $\mathrm{Pb}$ were found to be 
TABLE 4-6

PAH TEST RESULTS ON HIGHGROVE \#4 WHLE FIRING

NATURAL GAS WITH WOODGAS, MARCH 4, 1986

15 MW (7\% Woodgas-Thermal Basis)

\begin{tabular}{||l|c|c|c||}
\hline \multirow{2}{*}{ SPECIES } & \multicolumn{2}{|c|}{$\begin{array}{c}\text { AMOUNT MEASURED, } \\
\text { MICROGRAMS }\end{array}$} & $\begin{array}{c}\text { CONCENTRATION IN } \\
\text { FLUE GAS, } \\
\text { micrograms/dscm }\end{array}$ \\
\cline { 2 - 4 } & SAMPLE & BLANK & 0.25 \\
\hline \hline Phenanthrene & 0.37 & 0.16 & 0.005 \\
\hline Anthracene & 0.012 & 0.008 & 0.046 \\
\hline Fluoranthene & 0.088 & 0.050 & 0.018 \\
\hline Pyrene & 0.037 & 0.022 & 0 \\
\hline Cyclopenta[cd]pyrene & ND** & ND & 0.004 \\
\hline Benz[a]anthracene & 0.008 & 0.005 & 0 \\
\hline Chrysene & 0.021 & 0.021 & 0.002 \\
\hline Benzo[k]fluoranthene & 0.020 & 0.018 & 0.002 \\
\hline Benzo[e]pyrene & 0.006 & 0.004 & 0.001 \\
\hline Benzo[a]pyrene & 0.008 & 0.007 & 0 \\
\hline Indeno[1,2,3-cd]pyrene & 0.009 & 0.011 & 0 \\
\hline Benzo[ghi]perylene & 0.007 & 0.008 & \\
\hline
\end{tabular}

- Corrected for blank.

** Not detected. 


\begin{tabular}{|c|c|}
\hline \multicolumn{2}{|c|}{$\begin{array}{c}\text { Table 4-7 } \\
\text { PAH Emissions From Flare } \\
\text { November } 18,1987 \\
100 \% \text { Woodgas }\end{array}$} \\
\hline TEST SPECIES & $\begin{array}{c}\text { CONCENTRATION } \\
\mu \mathrm{g} / \mathrm{dscm}^{1}\end{array}$ \\
\hline Naphthalene & 0.85 \\
\hline 2-Methylnaphthalene & 0.28 \\
\hline 2-Chloronaphthalene & $\mathrm{ND}^{*}$ \\
\hline Acenaphthalene & $\mathrm{ND}^{*}$ \\
\hline Acenaphthene & ND* \\
\hline Fluorene & $\mathrm{ND}^{*}$ \\
\hline Phenanthrene & ND* \\
\hline Anthracene & $\mathrm{ND}^{*}$ \\
\hline Fluoranthene & ND* \\
\hline Pyrene & $\mathrm{ND}^{*}$ \\
\hline Benzo-A-anthracene & ND* \\
\hline Chrysene & ND* \\
\hline Benzo-B-fluoranthene & ND* \\
\hline Benzo-K-fluoranthene & ND* \\
\hline Benzo-A-pyrene & $\mathrm{ND}^{*}$ \\
\hline Indeno $(1,2,3-\mathrm{cd})$ pyrene & ND* \\
\hline Dibenz $(a, h)$ anthracene & $\mathrm{ND}^{*}$ \\
\hline Benzo $(g, h, i)$ perylene & ND* \\
\hline TOTAL PAH & 1.13 \\
\hline
\end{tabular}

1 microgram per dry standard cubic meter

* Detection limit - $0.41 \mu \mathrm{g} / \mathrm{dscm}$ 
retained substantially in the char at temperatures up to $750^{\circ} \mathrm{C}$. $\mathrm{Cd}$ was volatilized at temperatures greater than $600^{\circ} \mathrm{C}$ and $\mathrm{Hg}$ was completely evaporated at temperatures above $350^{\circ} \mathrm{C}$. As shown in Table 4-8, these findings correlate well with the calculated vapor pressures of these metals at these temperatures. Therefore, to estimate the potential for metals in wood to be retained in the char, metal vapor pressures were calculated at the estimated operating temperature range of the fluidized bed gasifier. The results, summarized in Table $4-9$, indicate that most of the metals expected to be present in construction/demolition (C/D) wood will remain in the char with the exception of arsenic, cadmium, mercury, and zinc. In addition, metals that are emitted from the fluidized bed gasifier in the form of particulate, or adsorbed onto particulate, would be effectively controlled by the facility's proposed particulate controls. A cyclone is used prior to the boiler to reduce particulate from the wood gas before combustion, and a baghouse is used as a final particulate control for the flue gas exiting the boiler.

\section{EMISSIONS SUMMARY}

Table 4-10 summarizes the expected emissions from the proposed Atlas Bio-Energy facility based on the previous discussions. These emissions are expected to comply with all state and federal air emissions regulations. 
Table 4-8

Metal to Vapor Conversion vs. Temperature

Comparing Swiss Federal Institute of Technology Study on Pyrolysis

To Known Vapor Pressures of Pure Elements

\begin{tabular}{|c|c|c|c|c|c|c|c|c|}
\hline & \multicolumn{4}{|c|}{$\begin{array}{c}\text { Percentage of Sludge Metals Found In Solid } \\
\text { Residue After Pyrolysis of Sludge }\end{array}$} & \multicolumn{4}{|c|}{$\begin{array}{c}\text { Vapor Pressure }(\mathrm{mm} \mathrm{Hg}) \\
\text { At Various Temperatures }\left({ }^{\circ} \mathrm{C}\right)\end{array}$} \\
\hline & \multicolumn{4}{|c|}{ Pyrolysis temperature, ${ }^{\circ} \mathrm{C}$} & \multicolumn{4}{|c|}{ Temperature $\left({ }^{\circ} \mathrm{C}\right)$} \\
\hline & 350 & 505 & 625 & 750 & 1610 & 750 & 625 & 505 \\
\hline Chromium & 103 & 96 & 93 & 87 & 1 & & & \\
\hline Nickel & 94 & 96 & 97 & 92 & $<1$ & & & \\
\hline Copper & 97 & 99 & 100 & 96 & $<1$ & & & \\
\hline Zinc & 98 & 97 & 99 & 96 & & 121.3 & 17.6 & 1.5 \\
\hline Lead & 98 & 96 & 98 & 91 & 396 & 0.016 & 0.0007 & 0.00001 \\
\hline Cadmium & 97 & 101 & 52 & 2 & & 626.7 & 122.2 & 15.5 \\
\hline Mercury & 2.9 & 2 & $<0.05$ & $<0.05$ & & 56928 & 21789 & 6483 \\
\hline
\end{tabular}


Table 4-9

Vapor Pressures of Potential Metals in Waste Wood At Various Gasification Temperatures

\begin{tabular}{|l|r|r|r|}
\hline & \multicolumn{3}{|c|}{ Vapor Pressure } \\
& $\begin{array}{l}\text { (mm Hg) } \\
\text { @ } 625^{\circ} \mathrm{C}\end{array}$ & $\begin{array}{c}(\mathrm{mm} \mathrm{Hg}) \\
\text { @ } 650^{\circ} \mathrm{C}\end{array}$ & $\begin{array}{r}(\mathrm{mm} \mathrm{Hg}) \\
\text { @ } 700^{\circ} \mathrm{C}\end{array}$ \\
\hline Arsenic & 1162 & 1882 & 4585 \\
Barium & $<<1$ & $<<1$ & $<<1$ \\
Cadmium & 122.2 & 175.6 & 342.8 \\
Chromium & $<1$ & $<1$ & $<1$ \\
Copper & $<<1$ & $<<1$ & $<<1$ \\
Lead & 0.0007 & 0.0015 & 0.0051 \\
Mercury & 21789 & 26958 & 39934 \\
Nickel & $<<1$ & $<<1$ & $<<1$ \\
Silver & $<<1$ & $<<1$ & $<<1$ \\
Titanium & $<<1$ & $<<1$ & $<<1$ \\
Zinc & 17.6 & 27.0 & 59.5 \\
\hline
\end{tabular}


Table 4-10

Bio-Energy Proposed Emission Rates

Max. Heat Input $=108.1 \mathrm{MMBtu} / \mathrm{hr} \mathrm{HHV}$ wood gas

\begin{tabular}{|l|c|c|c|l||}
\hline \multicolumn{1}{|c|}{ Pollutant } & $\begin{array}{c}\text { Emission Factor } \\
\text { lb/MMBtu }\end{array}$ & $\mathrm{lb} / \mathrm{hr}^{1}$ & $\mathrm{TPY}{ }^{2}$ & \multicolumn{1}{|c|}{ Basis } \\
\hline $\mathrm{PM}$ & 0.04 & 4.32 & 18.94 & $\begin{array}{l}\text { Wheelabrator (Baghouse ven- } \\
\text { dor) expected guarantee }\end{array}$ \\
\hline $\mathrm{NO}_{\mathrm{x}}$ & 0.05 & 5.41 & 23.67 & $\begin{array}{l}\text { Coen Co. (Burner vendor) } \\
\text { expected guarantee for low- } \\
\text { NO } \mathrm{O}_{\mathrm{x}} \text { burner }\end{array}$ \\
\hline $\mathrm{CO}$ & 0.20 & 21.62 & 94.70 & $\begin{array}{l}\text { Coen Co. (Burner vendor) } \\
\text { expected guarantees }\end{array}$ \\
\hline $\mathrm{HC}$ & 0.015 & 1.62 & 7.10 & $\begin{array}{l}\text { Coen Co. (Burner vendor) } \\
\text { expected guarantee }\end{array}$ \\
\hline $\mathrm{SO}_{2}$ & 0.10 & 10.81 & 47.35 & $\begin{array}{l}\text { Material balance and review of } \\
\text { wood combustion data }\end{array}$ \\
\hline
\end{tabular}

$1 \quad$ lb/MMBtu $x$ 108.1 MMBtu/hr

$2 \quad \mathrm{bb} / \mathrm{hr} \times 8,760 \mathrm{hr} / \mathrm{yr} \frac{1 \text { ton }}{2000 \mathrm{lb}}$ 


\section{INTRODUCTION}

Environmental impacts associated with conventional wood combustion involve air pollutant emissions and ash disposal. In a wood gasification power plant such as the proposed Atlas project, wood fuel is first gasified then combusted in a conventional steam generator. Emissions from a wood gasification power plant are expected to be lower than from conventional wood combustion and more similar to those from a natural gas or distillate oil fired boiler. The major air pollutant emissions include $\mathrm{NO}_{x}$ and $\mathrm{CO}$, with smaller amounts of VOC, $\mathrm{PM}$ and $\mathrm{SO}_{2}$.

The char from the gasifier contains carbon and minerals with low concentrations of the metals that are naturally present in wood. Note that the proposed Atlas project, in order to obtain permits as a combustion source rather than an incinerator, had to withdraw its original proposal to use $C / D$ wood which would have resulted in higher concentrations of metals in the char.

Normally, a small $3 \mathrm{MW}$ power plant of the size of the Atlas project, when fired with conventional fuels such as natural gas or distillate oil, would not be considered to be a concern from an environmental impact perspective. In fact, the New York State Environmental Quality Review (SEQR) determination was that the ".. project is an unlisted action and will not have a significant effect on the environment". A negative declaration was made and an environmental impact statement was not required for the project. However, due to the location of the proposed plant in an urban area and public misconceptions about the environmental impacts, this project has received some public opposition.

The objective of this section is to evaluate the environmental impacts from the proposed biomass gasification power plant compared to impacts representative of more conventional combustion technology for small power plants. The impacts of waste char characteristics on solid waste disposal options were qualitatively evaluated since sufficiently detailed quantitative data were not located on char composition. Air quality impacts were evaluated by developing comparative emission rates for the different technologies based on published emission factors and running computer dispersion models to estimate maximum ambient impacts for comparison to air quality standards.

\section{CHAR CHARACTERISTICS AND SOLID WASTE DISPOSAL IMPACTS}

The char from wood gasification will consist primarily of carbon and minerals from the wood and sand used as the fluidization media in the gasifier. Metals from the wood fuel will also tend to be concentrated in the char. In theory, due to the lower operating temperatures of a fluidized bed gasifier compared to a wood combustor, metals with relatively low vapor pressures would have less of a tendency to volatilize and 
partition to the particulate in the flue gas as they do in combustion systems; for example, lead, zinc, cadmium and mercury tend to distribute more to the fly ash than the bottom ash in a conventional wood combustor.

Therefore, there are theoretical environmental benefits to gasification of a $C / D$ waste wood stream in comparison to combustion in terms of lower metals emissions. However, no data were found to prove this theory or to adequately represent the characteristics of waste char to definitively assess the solid waste disposal impacts.

Managing of the char will require on-going testing in accordance with EPA's Toxic Characteristic Leaching Procedure (TCLP) to determine if it meets current definitions of non-hazardous waste. It is presumed that char from the Atlas gasifier will be relatively low in metals because C/D wood fuel will not be used in the process. However, the char will require disposal in a landfill.

For comparison to conventional small power plants, natural gas and distillate oil fired combustors do not have appreciable solid waste generation and accordingly have minimal solid waste disposal impacts. Conventional wood fired boilers generate ash in an amount typically ranging from 1 to 5 percent of the wood feed rate. Wood ash, depending on the wood fuel source, may be used beneficially as a soil amendment or for landspreading, or may be landfilled.

\section{COMPARING EMISSIONS TO CONVENTIONAL POWER PLANTS}

Table 5-1 summarizes emission factors developed for more conventional power plants based on EPA emission factors. Emission factors are summarized for a conventional spreader stoker wood boiler and for distillate oil and natural gas fired boilers in the same size range as the proposed Atlas project. Table 5-2 compares the emission rates (on a $\mathrm{lb} / \mathrm{MMBTU}$ and $\mathrm{lb} / \mathrm{hr}$ basis) for the proposed wood gasification power plant with those from the conventional power plant alternatives. The $\mathrm{lb} / \mathrm{hr}$ emission rates were based on the maximum rated capacity of the proposed Atlas project, $108 \mathrm{MMBTU} / \mathrm{hr}$.

Since the proposed project was required to meet stringent emission levels to obtain a permit to construct and operate, the emission factors for the alternative types of boilers were chosen to represent the level of control that would also be required if they were to be permitted in the New York City area. For example, the particulate emission factor for the wood boiler was representative of the addition of an electrostatic precipitator or baghouse. $\mathrm{NO}_{\mathrm{x}}$ emissions for each of the alternative boilers were representative of low-NO burners or add-on controls in the wood boiler.

Table 5-2 shows that particulate and $\mathrm{SO}_{2}$ emissions are the same for the wood gasifier and wood boiler. Particulate emissions are representative of the same level of control and $\mathrm{SO}_{2}$ emissions reflect the same 
Table 5-1

SUMMARY OF EMISSION FACTORS FOR CONVENTIONAL BOILERS

\begin{tabular}{|c|c|c|c|c|c|c|c|c|}
\hline Compound & $\begin{array}{c}\text { Woodboiler } \\
\text { AP-42 Sec. } 1 . \\
\text { lb/ton }\end{array}$ & $\begin{array}{l}6(1) \\
\mathrm{lb} / \mathrm{MMBTU}(3)\end{array}$ & $\begin{array}{c}\text { Wood Boiler } \\
\begin{array}{c}\text { Vendor (4) } \\
\text { Ib/ton }\end{array} \\
\end{array}$ & $\mathrm{Ib} / \mathrm{MMBTU}(3)$ & $\begin{array}{l}\text { Distillate OII BC } \\
\text { AP-42 Sec. } 1 . \\
\text { lb/1000 gal }\end{array}$ & $\begin{array}{l}\text { ler } \\
\text { Ib/MMBTU }\end{array}$ & $\begin{array}{c}\text { Natural Gas Bo } \\
\text { AP-42 Sec. } 1 . \\
\text { lb/MMCF }\end{array}$ & $\begin{array}{l}\text { Ter } \\
\text { Ib/MMBTU }\end{array}$ \\
\hline$P M$ & $0.17(2)$ & 0,019 & $3.843(5)$ & 0.427 & 2 & 0.014 & 6.2 & 0.006 \\
\hline NOX & 1.5 & 0,167 & $2.133^{\prime}$ & 0.237 & 20 & 0,142 & $81(7)$ & 0.081 \\
\hline SOx & 0.075 & 0.008 & & & $14.2(6)$ & 0.101 & 0.6 & 0.0006 \\
\hline $\mathrm{CO}$ & 13.6 & 1.511 & 4.122 & 0.458 & 5 & 0.035 & 61 & 0.061 \\
\hline TOC & 0.18 & 0.020 & 0.144 & 0.016 & 0.556 & 0.004 & 5.8 & 0.006 \\
\hline Arsenic & $8.8 E-05$ & $9.8 E-06$ & & & & $4.2 E-06$ & & \\
\hline Cadmium & $1.7 E-05$ & $1.9 E-06$ & & & & 1.1E-05 & & \\
\hline Chromium & $1.3 E-04$ & $1.4 E-05$ & & & & $6.7 E-05$ & & \\
\hline Lead & & & & & & $8.9 E-06$ & & \\
\hline Manganese & $8.9 E-03$ & $9.9 E-04$ & & & & $1,4 E-05$ & & \\
\hline Mercury & $6.5 E-06$ & $7.2 E-07$ & & & & $3.0 E-06$ & & \\
\hline Nickel & $5.6 E-04$ & $6.2 E-05$ & & & & $1.7 E-04$ & & \\
\hline Selenium & $1.8 E-05$ & $2.0 E-06$ & & & & & & \\
\hline Formaldehyd & $6.6 E-03$ & $73 E-04$ & $8.1 E-03$ & $9.0 E-04$ & $3.2 E-04$ & $2.3 E-06$ & & \\
\hline Acetaldehyde & $3.0 E-03$ & $3.3 E-04$ & & & & & & \\
\hline Benzene & $3.6 E-03$ & $4.0 E-04$ & $1.6 E-03$ & $1.7 E-04$ & & & & \\
\hline Naphthalene & $2.3 E-03$ & $2.6 E-04$ & & & & & & \\
\hline 2378 TCDD & $3.6 E-11$ & 4.OE-12 & & & & & & \\
\hline
\end{tabular}

Blanks indicate that no data were found.

\section{Footnotes:}
(1) Based on average of range of data contained in AP-42, Tables $1.6-1,2$, and 3
(2) with ESP for PM control
(3) Based on as-fired wood fuel w/ $50 \%$ by wt. moisture and $4500 \mathrm{BTU} / \mathrm{lb}$ higher heating value
(4) Average test data obtained from small wood boiler vendor (G\&S Mill, Inc.)
(5) No particulate control
(6) Assumes $0.1 \% \mathrm{~S}$ in oil
(7) Low NOx burner 
Table 5-2

COMPARISONOF GASIFIER/BOILEREMISSIONS WITH CONVENTIONALBOILER EMISSIONS

\begin{tabular}{|c|c|c|c|c|c|c|c|c|}
\hline \multirow[b]{2}{*}{ Compound } & \multicolumn{2}{|c|}{ Wood Gasifier } & \multicolumn{2}{|c|}{ Wood boiler } & \multicolumn{2}{|c|}{ Distillate Oil Boiler } & \multicolumn{2}{|c|}{ Natural Gas Boiler } \\
\hline & Ib/MMBTU & $\mathrm{Ib} / \mathrm{hr}$ & $\mathrm{Ib} / \mathrm{MMBTU}$ & $\mathrm{lb} / \mathrm{hr}$ & $\mathrm{lb} / \mathrm{MMBTU}$ & $\mathrm{lb} / \mathrm{hr}$ & $\mathrm{lb} / \mathrm{MMBTU}$ & $\mathrm{Ib} / \mathrm{hr}$ \\
\hline PM & 0.040 & 4.32 & $0.040(1)$ & 4.32 & 0.014 & 1.53 & 0.006 & 0.67 \\
\hline NOx & 0.050 & 5.41 & $0.167(2)$ & 18.02 & 0,142 & 15.33 & 0.081 & 8.76 \\
\hline SOx & 0.100 & 10.81 & $0.100(3)$ & 10.81 & 0.101 & 10.89 & 0.001 & 0.06 \\
\hline $\mathrm{CO}$ & 0.200 & 21.62 & $0.600(4)$ & 64.86 & 0.035 & 3.83 & 0.061 & 6.59 \\
\hline TOC & 0.015 & 1.62 & 0.020 & 216 & 0,004 & 0.43 & 0.006 & 0.63 \\
\hline Arsenic & & & $9.8 E-06$ & $1.1 E-03$ & $4.2 E-06$ & $4.5 E-04$ & & \\
\hline Cadmium & & & $1.9 E-06$ & $2.0 E-04$ & $1.1 E-05$ & $1.2 E-03$ & & \\
\hline Chromium & & & $1.4 E-05$ & $1.6 E-03$ & 6.7E-05 & $7.2 \mathcal{E}-03$ & & \\
\hline Lead & & & & & $8,9 E-06$ & $9.6 E-04$ & & \\
\hline Manganese & & & $9,9=-04$ & $1,1 \mathrm{E}-01$ & $1.4 E-05$ & $15 E-03$ & & \\
\hline Mercury & & & $7.2 E-07$ & $7.8 E-05$ & $3.0 E-06$ & $3.2 E-04$ & & \\
\hline Nickel & & & $6.2 E-05$ & $6.7 E-03$ & 1.7E-04 & $1.8 E-02$ & & \\
\hline Selenium & & & $2.0 E-06$ & $22 \mathrm{E}-04$ & & & & \\
\hline Formaldehyde & & & $73 E-04$ & $7.9 E-02$ & $2.3 E-06$ & $2,4 E-04$ & & \\
\hline Acetaldehyde & & & $3.3 E-04$ & $3.6 E-02$ & & & & \\
\hline Benzene & & & $4.0 E-04$ & 4.3E-02 & & & & \\
\hline Naphthalene: & & & $26 E-04$ & $2.8 E-02$ & & & & \\
\hline 2378 TCDD & & & $4.0=-12$ & $4.3 E-10$ & & & & \\
\hline
\end{tabular}

Blanks indicate that no data were found.

(1) With ESP or baghouse, representative of BACT for PM.

(2) With SNCR, representative of BACT for NOx.

(3) Fuel dependent. Representative of BACT for SOx.

(4) Representative of BACT for CO for small wood boiler. 
level of sulfur content in the wood fuel. It should be noted that this sulfur level is considered to be conservatively high for clean wood combustion or gasification. $\mathrm{NO}_{\mathrm{x}}$ and $\mathrm{CO}$ emissions from the wood gasifier are significantly lower than those from a wood boiler primarily because the gasified wood will burn more predictably and at lower temperatures than wood fuel in a wood-fired boiler. Hydrocarbon emissions from the wood gasifier are estimated to be slightly lower than from a wood boiler. Overall, the wood gasifier/boiler is expected to result in lower emissions than a similarly sized wood boiler.

Compared to conventional distillate oil combustion boilers, the wood gasifier will have higher PM, CO and hydrocarbon emissions. Depending on the sulfur content of the wood fuel, $\mathrm{SO}_{2}$ emissions could be much lower, but in no case will they be higher than the level of $\mathrm{SO}_{2}$ emissions from the combustion of 0.1 percent distillate fuel oil. Due to the proposed use of a low- $\mathrm{NO}_{\mathrm{x}}$ burner on the wood gas boiler, $\mathrm{NO}_{\mathrm{x}}$ emissions from the wood gasifier system will be about one-third of the emissions from an equivalently sized distillate oil boiler with a low- $\mathrm{NO}_{\mathrm{x}}$ burner.

Compared to conventional natural gas fired boilers, the wood gasifier will have higher $\mathrm{PM}, \mathrm{SO}_{2}, \mathrm{CO}$, and $\mathrm{HC}$ emissions. $\mathrm{NO}_{\mathrm{x}}$ emissions from the gasification boiler will be slightly lower or comparable to those from a natural gas boiler equipped with a low- $\mathrm{NO}_{\mathrm{x}}$ burner.

There are insufficient data to compare emissions of non-criteria or hazardous air pollutants from a wood gasification boiler to those of a wood combustion boiler. As previously discussed, in theory, a wood gasifier is expected to have lower metals and organic emissions. The lower operating temperature of the gasifier should result in less volatilization of metals and the gas burner in the boiler should efficiently oxidize the volatile organics formed in the gasifier.

Comparison of published metals emissions data from distillate oil combustion with that from wood combustion shows that distillate oil combustion will result in slightly higher emissions of cadmium, chromium, lead, mercury, and nickel and slightly lower emissions of arsenic and manganese. It should be noted that these results are highly dependent on the wood fuel composition. For example, combustion of wood fuel obtained from $C / D$ or treated wood sources could contain higher levels of metals such as lead, arsenic, chromium, copper, titanium, and zinc.

\section{MODELING OF AMBIENT IMPACTS}

In order to compare the ambient air quality impacts associated with the alternative types of power plants, an air quality impact analysis was performed in accordance with the "Screening Procedures for Estimating the Air Quality Impact of Stationary Sources, Revised" (EPA, 1992). A unit emission rate of 1 gram/second was modeled and the results were then scaled by the actual emission rates for each pollutant and each combustion alternate. 


\section{Model Selection}

The SCREEN2 model was selected to perform the air dispersion modeling analysis. SCREEN2 can perform all of the single source, short-term calculations including estimating maximum ground-level concentrations, incorporating the effects of building downwash on the maximum concentrations for both the near wake and far wake regions, and estimating concentrations in the cavity recirculation zone. The model is also capable of incorporating the effects of simple elevated terrain on maximum concentrations.

\section{Urban/Rural Determination}

The Auer technique, which is one of the EPA's preferred techniques, was used in the urban/rural determination. This technique recognizes four primary land use types: industrial, commercial, residential, and agricultural. Practically all industrial and commercial areas come under the heading of urban while agricultural areas are considered rural. For residential areas, Auer subdivides this land use type into four groups based on the character of building structures and associated vegetation.

Based upon the Auer criteria, an analysis was conducted of the land use characteristics of the area surrounding the proposed facility. First, the location of the Atlas facility was noted on an USGS Brooklyn Quadrangle and a circle with a radius of three kilometers was drawn about the source. The land use patterns of the area within the circle were then examined to determine the appropriate dispersion regime. Generally speaking, those areas on a topographic map which are shaded gray (or red) can be considered as urban in character, while those areas which shaded green are rural. White areas on the map can be either urban or rural depending on the specific land use of the area (e.g., commercial, industrial, etc.). Using these criteria, a visual analysis of the topographic map revealed that the area within a three kilometer radius of the facility is primarily urban.

\section{Receptors}

Receptors were placed along a radius at 100 meter intervals out to 2 kilometers from the source. The simple elevated terrain option was used in the modeling. For receptors with a distance less than one kilometer from the source, the highest terrain elevation within the circle with a radius of one kilometer was assigned for each receptor. For receptors with a distance between one kilometer to two kilometers, the highest terrain elevation within the one-kilometer and two-kilometer circles was assigned for each receptor. Also, a receptor was located at the end of the cavity zone.

\section{Building Dimensions}

The SCREEN2 model contains algorithms to account for both building downwash and cavity effects of a building. The cavity calculations in SCREEN2 are based largely on results published by Hosker (1984). The concentration within the cavity, $\mathrm{X}_{\mathrm{c}}$, is assumed to be uniform and estimated by the following approximation:

$$
X_{c}=Q /\left(1.5 A_{p} u\right)
$$


where:

$\begin{array}{lll}\mathrm{Q} & = & \text { emission rate }(\mathrm{g} / \mathrm{s}) \\ \mathrm{A}_{\mathrm{p}} & = & \mathrm{H}_{\mathrm{b}} \mathrm{W}=\text { cross-section area of the building normal to the wind }\left(\mathrm{m}^{2}\right) \\ \mathrm{H}_{\mathrm{b}} & = & \text { building height }(\mathrm{m}) \\ \mathrm{W} & = & \text { crosswind dimension of the building }(\mathrm{m}) \\ \mathrm{u} & = & \text { wind speed }(\mathrm{m} / \mathrm{s})\end{array}$

Building information required in the SCREEN2 input file include the building height, and the minimum and maximum horizontal building dimensions. For a building with multiple tiers or structures, an appropriate specification of the building dimensions is important for the analysis. The tiers or structures which may produce downwash and cavity effects for air emissions from the stack are the baghouse and the gasifier area building. Based on the cavity concentration calculation method presented above, the building dimensions were specified by the dimensions of the equivalent rectangular cross-section area. More specifically, the baghouse height of $64 \mathrm{ft}(19.5 \mathrm{~m})$, the width of the equivalent rectangular cross-section of $42.2 \mathrm{ft}$ (12.87 $\mathrm{m}$ ) and the building length of $165 \mathrm{ft}(50.3 \mathrm{~m})$ were used to present the building height, and the minimum and maximum horizontal dimensions, respectively.

\section{Input Data and Options}

The input data and options used in the modeling are presented in Table 5-3.

\section{Modeling Results}

The modeling results are summarized in Table 5-4. It can be seen that the predicted impacts from each technology alternative are in compliance with the National Ambient Air Quality Standards (NAAQS). Therefore, based on the results of this analysis, each technology would be expected to be able to obtain air permits in the New York City area by demonstrating compliance with NAAQS. 


\begin{tabular}{|c|c|}
\hline \multicolumn{2}{|c|}{$\begin{array}{c}\text { Table 5-3 } \\
\text { Input Data and Options }\end{array}$} \\
\hline Parameter & Input \\
\hline Emission Rate (g/s) & 1.0 \\
\hline Stack Height (m) & 22.5 \\
\hline Stack Diameter (m) & 0.9906 \\
\hline Exit Velocity (m/s) & 25.2 \\
\hline Gas Exit Temperature (K) & 449.8 \\
\hline Ambient Temperature (K) & 293 \\
\hline Building Height (m) & 19.5 \\
\hline Min. Horiz. Bldg. Dim. (m) & 12.87 \\
\hline Max. Horiz. Bldg. Dim. (m) & 50.3 \\
\hline $\begin{array}{c}\text { Receptor Elevation (m) } \\
\text { (Distance less than 1000 } \mathrm{m})\end{array}$ & 5 \\
\hline $\begin{array}{c}\text { Receptor Elevation (m) } \\
\text { (Distance greater than 1000 m) }\end{array}$ & 11 \\
\hline Urban/Rural Option & Urban \\
\hline Meteorology & Full Meteorology \\
\hline
\end{tabular}


Table 5-4

SUMMARY OF AIR QUALITY IMPACT ANALYSIS RESULTS

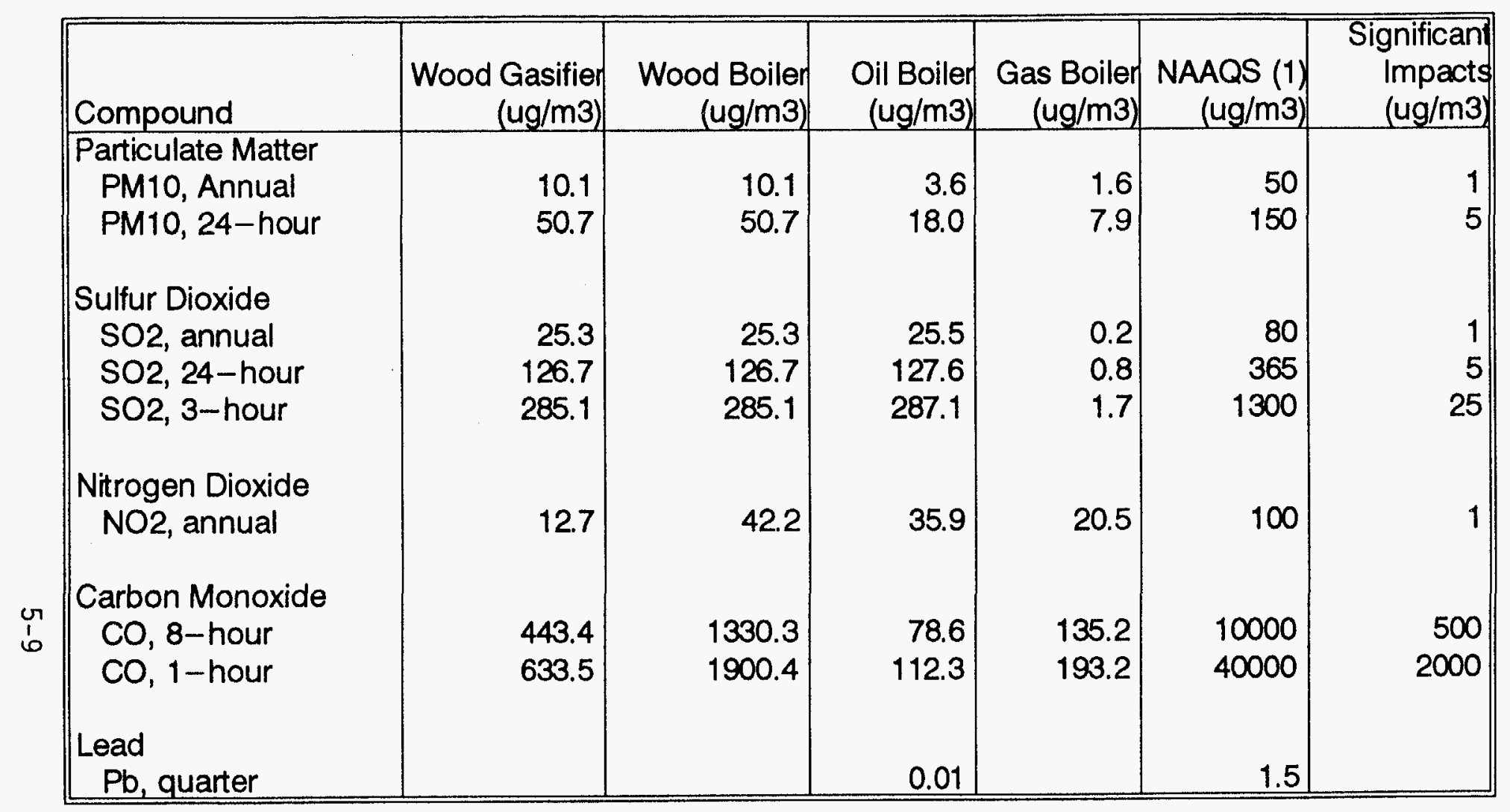

(1) Air quality modeling results based on normalized 1-hour impact of $29.3 \mathrm{ug} / \mathrm{m} 3 \mathrm{per} 1 \mathrm{lb} / \mathrm{hr}$ emission rate. The following EPA factors used to convert 1-hour impacts to longer averaging periods:

$\begin{array}{lr}\text { 3-hour } & 0.9 \\ \text { 8-hour } & 0.7 \\ \text { 24-hour } & 0.4 \\ \text { Annual } & 0.08\end{array}$


Section 6

PRELIMINARY ECONOMIC ANALYSIS

\section{INTRODUCTION}

A preliminary economic model was developed to evaluate the economics of a fluidized bed gasification/package steam boiler system and to compare the economics to those of conventional combustion technology for electric power generation. Three equipment configurations were considered:

1. Gasifier + Steam Turbine

2. Stoker Boiler + Steam Turbine

3. Gasifier + Combustion Turbine

Each equipment configuration was evaluated at two output sizes: $3 \mathrm{MW}$ and $30 \mathrm{MW}$. The $3 \mathrm{MW}$ size reflects the scale of the wood gasifier project being developed by Atlas Bio-Energy. The $30 \mathrm{MW}$ size was chosen to represent a project utilizing the economy of scale factor.

\section{MECHANICS OF THE SPREADSHEET OPERATION}

The economic model is contained in a Lotus 1-2-3 There are actually three spreadsheet pages linked together. The Input Section is on Page D, the Total Capital Investment is developed on Page B, and Page C contains the Cash Flow figures for the chosen life of the project. Pressing ctrl + [page up] or [page down] steps the user between the linked sheets. Values from the Input Section and Total Capital Investment pages are automatically entered into the Cash Flow Spreadsheet. The layout of Pages B and C is as follows: Case 1 is at "home", then using the [page down] key, Case 2 is found below Case 1, Case 3 is below Case 2, etc.

\section{INPUTS TO THE MODEL - GENERAL USER}

The following categories are input by the user:

$\begin{array}{ll}\text { - } & \text { Hours of operation/year } \\ \text { - } & \text { Eross power output } \\ \text { - } & \text { Tons of wood chips consumed per hour } \\ \text { - } & \text { Ash disposal costs } \\ \text { - } & \text { Percent ash } \\ \text { - } & \text { Laborator and sewer fees } \\ \text { - } \quad \text { Purchased fuel costs } \\ \text { - } \quad \text { O\&M Other }\end{array}$


- Annual O\&M escalating factor

- Energy sales to utility, $\$$ /kwh

- Tipping fees

- Taxes

- Fixed capital investment

- Debt and equity percent

- Annual interest rate

The following input categories are calculated by the spreadsheet (factors used in the calculation):

- Annual cost of ash disposal (ash disposal costs/ton, percent ash in the wood)

- Annual cost of feedstock (purchased fuel cost if greater than zero, tons of wood chips consumed per hour, hours of operation per year)

- Spare parts and consumables (4\% of fixed capital investment, FCI)

- Repairs/contract labor (3\% of FCI)

- Major overhaul reserve $(1.5 \%$ of $\mathrm{FCl})$

- Insurance ( $1 \%$ of FCI)

- Depreciation (Straight line, 30 year life)

- $\quad$ Salvage Value ( $1 \%$ of $\mathrm{FCI})$

For the Fixed Capital Investment table, costs are required for the major pieces of equipment and balance of plant. The following components of fixed capital investment are percentages of the equipment prices: Engineering and Supervision (8\%), Construction Expense and Contractor's Fee (15\%), Construction Permits (3\%), and Contingency (10\%).

Note that the model uses a levelized rate for power sales and includes a 3\% annual escalating factor for operating and maintenance expenses.

INPUTS TO THE MODEL - THIS STUDY

\section{$\underline{\text { Personnel }}$}

Twelve people at an average salary and fringe benefits cost of $\$ 30,000$ was used for the $3 \mathrm{MW}$ plant. Thirty people at an average cost of salary and fringe benefits of $\$ 30,000$ was used for the $30 \mathrm{MW}$ plant.

\section{Taxes}

State and local taxes were assumed to be $9 \%$ of the taxable income, Federal taxes were assumed to be $34 \%$ of the taxable income. Tax credits for energy production from biomass sources were assumed to be inapplicable.

\section{Financial}

A $25 \%$ equity in the facility was assumed. The annual interest rate was assumed to be $10 \%$. The life of loan was assumed to be 30 years. No calculation of return on investment was made. Straight line depreciation was used. A salvage value of $10 \%$ of the fixed capital investment was used. 


\section{Utility Sales}

For both the $3 \mathrm{MW}$ and $30 \mathrm{MW}$ plants, a rate of $8.17 \mathrm{cents} / \mathrm{kwh}$ was used. This rate was derived from the average power purchase rate contained in the contract between Consolidated Edison of New York and Atlas Bio-Energy. This is a beneficial rate that allows the project to be economically viable. As of this writing, similar projects would not be able to obtain a purchase rate above the published tariff rate SC\#11 for buyback of power not to exceed $2 \mathrm{MW}$. The current value of this buyback rate is $1.748 \mathrm{cents} / \mathrm{kwh}$. At this rate the plant would show a negative cash flow.

\section{Retail Power Offset}

The $3 \mathrm{MW}$ plant assumes that a maximum of $2 \mathrm{MW}$ would be sold to Consolidated Edison under the terms of the power purchase contract. The plant itself would consume about $0.3 \mathrm{MW}$ to operate fans, pumps and other auxiliary equipment. This leaves $0.7 \mathrm{MW}$ of the plant's generating capacity that could be used to provide power to other on-site equipment. The value of that power is in the displacement of electric power purchased under normal retail rates. In the New York City area this retail rate is approximately 14 cents/kwh; therefore, the remaining $0.7 \mathrm{MW}$ is valued as a credit to the project based on the retail power purchase rate. No such assumption was made for the $30 \mathrm{MW}$ project; larger power projects generally sell all of their available net generating capacity under a power contract.

\section{Laboratory Costs}

The laboratory charges are estimated from the ash testing requirements of Atlas's solid waste permit (weekly testing for volatiles, semi-annual tests for leaching and content) plus an additional $\$ 2,000$ per year for standard water tests.

\section{Ash Disposal Costs}

The charge for ash disposal is $\$ 45 /$ ton at the quantity produced by the $3 \mathrm{MW}$ plant and $\$ 38 /$ ton for the quantity produced by the $30 \mathrm{MW}$ plant. The calculation for the annual ash production assumes $5 \%$ ash (pounds of ash out/pounds of wood chips in) produced in the gasifier cases and $3 \%$ ash produced in the stoker fired boiler cases.

\section{Water and Sewer Charges}

Water and sewer charges in New York City are $\$ 2.63 / 100 \mathrm{ft}^{3}$. A 50 gallon per minute consumption rate was assumed for the $3 \mathrm{MW}$ plant and a 500 gallon per minute consumption rate was assumed for the $30 \mathrm{MW}$ plant.

\section{Equipment}

Vendor estimates were obtained for the major pieces of equipment. The remainder of the plant estimate includes installation costs, plant auxiliaries and piping. 


\section{Feedstock Costs}

A tipping fee (revenue) of $\$ 30 /$ ton was used for the $3 \mathrm{MW}$ facility based on Atlas Bio-Energy estimates. A tipping fee of $\$ 15 /$ ton was assumed for the $30 \mathrm{MW}$ power plant. These figures are based on limited information on prevailing commercial prices in the metropolitan New York area and may be subject to considerable variation.

\section{Annual Hours of Operation}

7500 hours of operation per year was assumed for all $3 \mathrm{MW}$ cases. A higher capacity factor was assumed for the $30 \mathrm{MW}$ cases - 8000 hours per year.

\section{RESULTS OF THE ECONOMIC MODEL}

Based on the terms of the power contract between Atlas and Con Edison, and the tipping fees charged by Atlas for acceptance of waste wood for fuel, the $3 \mathrm{MW}$ project shows a positive cash flow over the entire plant life. As previously discussed, a similar facility operating under currently available buyback rates would have operating losses in nearly all years and would have a negative retum on investment. The 30 year average net profit (net income/kwh sold) and cumulative cash flows for the $3 \mathrm{MW}$ cases are as follows:

3 MW PLANTS

\begin{tabular}{|l|c|c||}
\hline & $\begin{array}{c}\text { Net Profit } \\
\$ / \mathrm{kwh} \text { sold } \\
(30 \mathrm{yr} \text { average })\end{array}$ & $\begin{array}{c}30 \text { year } \\
\text { cumulative } \\
\text { cash flow } \\
\text { (million \$) }\end{array}$ \\
\hline Case 1 Gasifier - Steam Turbine & 0.069 & 40.4 \\
\hline Case 2 Stoker Boiler - Steam Turbine & 0.011 & 3.4 \\
\hline Case 3 Gasifier - Combustion Turbine & 0.031 & 12.7 \\
\hline
\end{tabular}

As can be seen in the table above, Case 1 has both the highest profitability $(\$ / \mathrm{kwh})$ and the highest 30 year cumulative cash flow. This is due in large part to the revenue produced by tipping fees charged for acceptance of waste wood used as fuel, and by the internal use of power generated on-site to displace purchased utility power. Case 1 has the highest fuel consumption and, therefore, the lowest fuel efficiency of the $3 \mathrm{MW}$ plants analyzed. If tipping fees are charged for the acceptance of fuel, this relative inefficiency is economically beneficial to the project.

For the larger $30 \mathrm{MW}$ plant, the economy of scale is demonstrated and net profits are also positive for all cases. The cumulative cash flows are greater although the net profit per kwh remains nearly the same as in the preceding three cases. The 30 year average net profit (net income/kwh sold) and cumulative cash flows for the $30 \mathrm{MW}$ cases are as follows: 


\begin{tabular}{|l|c|c|}
\hline & $\begin{array}{c}\text { Net Profit } \\
\text { \$/kwh sold } \\
(30 \mathrm{yr} \text { average })\end{array}$ & $\begin{array}{c}30 \text { year } \\
\text { cumulative } \\
\text { cash flow } \\
\text { (million \$) }\end{array}$ \\
\hline Case 4 Gasifier - Steam Turbine & 0.034 & 315.5 \\
\hline Case 5 Stoker Boiler - Steam Turbine & 0.027 & 127.2 \\
\hline Case 6 Gasifier - Combustion Turbine & 0.031 & 137.6 \\
\hline
\end{tabular}

As with the $3 \mathrm{MW}$ case, the project with the greatest fuel inefficiency, case 4 , has the best profitability $(\$ / k w h)$. This result is due to the favorable tipping fee and power contract assumptions, which were similar to those for the $3 \mathrm{MW}$ plant.

Other cases were run with the economic model to evaluate the sensitivity of the model to different assumptions. For example, the model was run for the $30 \mathrm{MW}$ cases with the assumption that wood chips would be purchased rather than generate revenue through tipping fees. With the assumption of a fuel cost of $\$ 17 /$ ton, case 4 would only be profitable for the first 13 years, after which it would lose money due to the high fuel consumption and escalation of fuel and $O \& M$ costs. When fuel is purchased, case 5 , which has the best fuel efficiency, will also have the best profitability.

In summary, the analyses of these types of plants demonstrates that if the primary purpose is to generate electrical power using purchased fuel, the gasifier-boiler-steam turbine configuration is unlikely to be profitable. Other more proven technology such as the stoker fired boiler and steam turbine, or the gasifier and combustion turbine combination, are more fuel efficient and therefore more profitable as a means of generating electrical power for sale. If the need is for generation of smaller amounts of electrical power used to displace purchased utility power at an existing facility, and if the acceptance of the waste wood fuel can generate revenue from tipping fees, then the gasifier-boiler-steam turbine would become economically attractive.

Full printouts of the model inputs, capital investment calculations, and cash flow analyses for each case are provided in Appendix A. 


\section{Section 7}

\section{OPERATING/TECHNOLOGY LIMITATIONS}

\section{INTRODUCTION}

This section provides an overview of the potential operational problems with biomass gasification systems that were identified from a literature review as requiring further research. Identifying areas of concem is important to develop a comprehensive test plan for the demonstration program (i.e., identifying specific operating characteristics to be monitored).

In general, problems with erosion, corrosion, fouling and slagging, bed maintenance requirements, and tar formation are known to occur and will influence operation. Gasifiers tend to have more frequent maintenance requirements and longer initial start-up programs to fine-tune operating conditions than traditional combustors. Cycling between operating conditions and partial or complete shutdown causes thermal stresses on the equipment, and operating during less than optimum conditions leads to increased slagging and fouling.

Much of the downtime may be due to the relative newness of biomass gasifiers and because they lack the widespread use and operating history of traditional combustors. Gasifiers are on the beginning of the learning curve for large (greater than pilot or lab) scale operations. The ultimate, fully developed biomass gasifier operation may compare favorably to biomass combustors but the following operating problems need to be resolved.

\section{ASH $^{11,12}$}

Ash is carried out of the gasifier in the gas stream and de-entrained from the gas stream in the cyclone. If there is insufficient removal, fine char-ash dust can clog the burner and boiler. The ash can also cause erosion in the heat exchanger passes.

Operators need to carefully monitor ash formation and remove the ash before accumulation and sintering become problematic. If ash slagging occurs, those particles are harder and more abrasive than char and ash particles, and can cause severe wear.

\section{ASH - SOLID WASTE MANAGEMENT ${ }^{13}$}

Solid waste management of the ash requires on-going testing of the ash in accordance with EPA's Toxic Characteristic Leaching Procedure (TCLP) to determine if it meets current definitions of non-hazardous waste. This requirement stems from conditions of the solid waste permit and contracts with the landfill operators that the waste they receive is "non-hazardous." Side benefits of a consistent ash sampling program 
are that gasification performance can be monitored and the ash composition data would yield a check on feedstock contamination.

Alternatives for landfilling are desirable but would require testing the ash for TCLP and other characteristics before landspreading or use in compost or soil amendment products. In addition, while wood ash is known to be a valuable soil amendment, the ash from circulating fluidized bed gasifiers will actually be ash+char+slag+sand and would need to be tested for its nutrient content before its value as a soil amendment can be assumed.

TARS $^{11,12,13}$

Tars can cause downstream moving parts to stick. Tars at operating temperatures can be viscous fluids but turn into a hard vamish if the system cools. This is particularly a problem on moving parts such as valves.

With hot gas cleanup, tar removal is not needed since it stays as a vapor until it is burned in the combustor. Hot gas temperatures would prevent alkali compounds from condensing on the particulate thus necessitating their separate removal.

Tar formation increases as the moisture content of the fuel increases. Careful control and operation of the gasifier is required to minimize tar formation.

\section{ALKALI CLEANUP ${ }^{15}$}

Alkali refers to the sum of potassium and sodium compounds. Living plants use potassium and sodium ions in their biological processes. Tree trunks and larger branches contain the least amounts of these alkali metals; small branches, twigs, and foliage contain the highest percentage. These potassium and sodium compounds form oxides during gasification (during combustion for traditional combustors) that can deposit elsewhere in the process.

The alkali deposits can agglomerate in the fluidized bed and shut down operations. Manual labor is required to breakup and remove the agglomerated portions of the bed. The alkali deposits can collect on walls, ledges and other surfaces. Fine deposits can foul the superheater. If thick deposits form in the cyclone, they can break off and fall, plugging the return leg.

For flue gas temperatures from 500 to $600^{\circ} \mathrm{C}$, most of the alkali compounds condense on the particulate and can be controlled through particulate clean-up. There is a balance required though; higher temperatures would decrease the amount of tar formation and subsequent problems with tar. 


\section{MISCELLANEOUS ${ }^{12}$}

If chlorine or sulfur are present in the fuels in appreciable amounts, they will also be part of the deposits that form downstream and can lead to corrosion problems.

Dust, tar and corrosive (carbon dioxide, organic acids, and ammonia) components of the gas can also cause wear of mechanical parts downstream.

\section{FEEDSTOCK}

Fuel quality and consistency has a major influence on the operation of both circulating fluidized bed gasifiers and traditional combustors. The wood chips size, moisture content, presence of dust/fines and presence of debris all have effects.

Both oversized materials and fines will interfere with steady state operation of the gasifier or combustor beds. Depending on the amount of fines in the feed and the type of storage and transfer operations used, fugitive dust may be a concern.

The presence of a large amount of fines or debris will require more frequent bed maintenance. However, the bottom ash clarifiers work best under steady-state operation. As they are an important component of bed quality control, any decrease in the bottom ash clarifiers' effectiveness influences the combustion of the bed.

A high ash content in the fuel will require more frequent blow-down of the bed that in turn uses more fresh sand make-up and creates more ash+sand+char for eventual disposal. In addition, fresh sand may be more abrasive than sand that has been in circulation and higher use of fresh sand could increase erosion effects throughout the system.

If the moisture content of the feed varies considerably, the steadiness of the bed operation would be affected and might require using pre-dryers for the wood chips.

\section{PRODUCER GAS COMPATIBILITY WITH CONVENTIONAL COMBUSTION EQUIPMENT T2,16,17}

For gas turbine applications, a specific problem with the application of producer gas in engines is the fluctuating caloric value of the gas. This leads to changing engine power. Again, the longest equipment life is, in general, at steady operating conditions without surges or abrupt changes.

The producer gas must be cleaned free of particulates and other contaminants such as trace alkali metals. The operation of a gas turbine is particularly sensitive to the gas stream's cleanliness. 
If the gas temperatures are in the region 500 to $600^{\circ} \mathrm{C}$, most of the alkali compounds will condense on the particulate and be removed with it in the cyclone. If the gas temperatures are higher, this does not hold, and the alkalis must be removed from the producer gas stream. Fluidized bed gasifiers have higher exit temperatures $\left(800\right.$ to $\left.900^{\circ} \mathrm{C}\right)$ than fixed bed gasifiers. At these temperatures, alkalis will be in the vapor phase. There may be also be more particulate carryover with fluidized bed gasifiers.

\section{FOULING AND SLAGGING ${ }^{15,16}$}

The coal industry uses the following formula to roughly predict which coals will form slags and foul.

$$
\frac{1 \times 10^{6} \text { Btu/MMBtu }}{B t u / l b(d r y)} \times \text { ash\% } \times \text { alkali\% of the ash }=\frac{l b \text { alkali }}{M M b t u}
$$

$0-0.4 \mathrm{lb} / \mathrm{MMB}$ tu - fairly low slagging risk

0.4-0.8 lb/MMBtu - probably slag

$>0.8 \quad$ - almost certainly slag and foul

T. R. Miles found this relationship to hold true in field tests of several types of biomass and found that urban waste wood at $0.5 \mathrm{lb} / \mathrm{MMBtu}$ "slags to an annoying and barely manageable degree."

Some sodium and potassium salts can form low melting point compounds (eutectics). These molten materials add to slagging problems. Limestone or kaolin can be added to absorb molten material or form compounds with higher melting points.

\section{SAFETY $Y^{11,18}$}

From a safety standpoint, the gasifier must be leak-tight to prevent emission of carbon monoxide. Carbon monoxide gas is produced during start-up and shutdown conditions, and can continue to be produced for hours after the gasifier is shutdown. While the gasifiers may be intended for continuous operation, there will be occasions, such as maintenance and repair, that will require shut-down and subsequent startup, especially those portions of the entire gas system that normally operate under negative pressure and might be less of a concern for leakage outward.

An additional safety concern with gasifiers is the explosivity of the fuel-rich atmosphere. This is of greatest concern during start-ups and shut-downs. Once at steady state operation, the gases are vented to the boiler which has traditional, standard safety features developed over its long operating history. 


\section{TEMPERATURE}

A common theme of the operating problems previously identified is the influence of temperature. Many of the "problems" interact with each other, generally in a negatively synergistic manner, but a balance can be developed and maintained for successful, long-term operation of a gasifier. Coming up with this balanced condition, however, may take significant development time with each gasifier set-up.

Temperature control is critical at each step. In the gasifier itself, temperature is controlled by the feed rate: the temperature increases with feed rate until the atmosphere becomes so rich that the temperature starts to decrease. High temperatures result in the production of low-tar gas. The downside is that at high temperatures out of the gasifier, the alkali compounds are still vapors and will require separate clean-up. High temperature operation may require using of low-ash fuel to prevent slagging.

In the boiler, if the combustion gases from the boiler do not have sufficient residence time to complete the combustion process before reaching the heat transfer surfaces, the particulate is still molten and will form slags on the (relatively) cooler membrane or water wall.

The gasifier itself has no maintenance parts per se; however, the critical part is the refractory lining. The lining can erode from the sand, but according to one manufacturer ${ }^{18}$, their current recommended refractory lining can last up to 10 years if sand erosion is the limiting factor. In practice, however, the greatest challenge to the integrity of the refractory lining is thermal shock. Temperature ramps from 100 to $200^{\circ} \mathrm{F} / \mathrm{h}$ are recommended; frequent shut-downs and/or quick ramps up to operating temperature cause considerable thermal stresses that shorten the life of the lining. 


\section{REFERENCES}

1. Horizon Engineering, Oregon, "Stack Emissions Test Report: Catalyst North Powder Wood Fired Generating Plant at North Powder, Oregon," November 16-17, 1988.

2. California Air Resources Board, Stack Emissions Tests from Biomass Gasification System Located at 6th and Q Streets, State Central Heating Plant, Sacramento, CA, Engineering Evaluation Branch Test Report, Dec., 1983.

3. Larson, L.E., Rundstrom, D.A., "Operating Experience with a Wood Fueled Downdraft Gasifier at the Highgrove Generating Station," Presentation at the American Institute of Chemical Engineers Spring National Meeting, New Orleans, LA, March 6-10, 1988.

4. Facsimile transmittal from Lori Bartels, Minnesota Pollution Control Agency/Air Quality Division regarding, and including, excerpts from reporting of emissions testing at Potlatch Corporation, Bemidji, Minnesota (Draft, May 23, 1989).

5. Ferrero, G.L., et. al., Editors, Pyrolysis and Gasification, Elsevier Applied Science, London and New York, 1989, pg. 603.

6. Oglesby, H.S. and Blosser, R.O., "Information on the Sulfur Content of Bark and its Contribution to $\mathrm{SO}_{2}$ Emissions when Burned as a Fuel," Journal of the Air Pollution Control Association, Volume 30, No. 7, July 1980, pp. 769-772.

7. Kaiser, Elmer R., "The Sulfur Balance of Incinerators," Journal of the Air Pollution Control Association, Volume 18, No. 3, March 1968, pp. 171-174.

8. Abbasian, Javad and Rehmat, Amir, "Reaction of Calcium-Based Sorbents with Sulfur Compounds During Gasification," Gas Research Institute, GRI-91-0396, December, 1991.

9. Kistler, R.C., Widmer, F., and Brunner, P.H., "Behavior of Chromium, Nickel, Copper, Zinc, Cadmium, Mercury, and Lead during the Pyrolysis of Sewage Sludge," Environmental Science Technology, Volume 21, No. 7, 1987, pg. 704.

10. Weast, Robert C., Editor-in-Chief, CRC Handbook of Chemistry and Physics, 65th Edition, CRC Press, Inc., Boca Raton, Florida, 1985.

11. Reed, Thomas B., and Das, Aqua, Handbook of Biomass Downdraft Gasifier Engine Systems, March 1988.

12. Buekens, A.G., Bridgewater, A.V., et al., Commercial and Marketing Aspects of Gasifiers, Commission of the European Communities, 1990.

13. Larson, Eric D. "A Developing-Country-Oriented Overview of Technologies and Costs for Converting Biomass Feedstocks into Gases, Liquids, and Electricity." PU/CEES Report No. 266, November 1991, The Center for Energy and Environmental Studies, Princeton University.

14. New York State Roundtable on Wastewood Processing and Combustion for Fuel, Final Report. Project Cosponsers: New York State Research and Development Authority and USEPA Northeast Regional Biomass Program, Sept. 23, 1992. 


\section{REFERENCES (CONTINUED)}

15. Miles, T.R., "Alkali Deposits in Biomass Power Plant Boilers," EPRI TR-103146s, Electric Power Research Institute.

16. Howe, W.C., and Divilio, R.J., "Fluidized Bed Combustion Experience with Alternative Fuels," EPRI TR-103146s, Electric Power Research Institute.

17. Wilhelm, Donald J., and Simbeck, Dale R., SFA Pacific, Inc., "The California FBC Boiler Story, A Status Report," presented at the Council of Industrial Boiler Owners, Sixth Annual FBC Conference, December 9-11, 1990.

18. Brands, David, Energy Products of Idaho (EPI), phone conversation, October 28, 1994. 


\section{BIBLIOGRAPHY}

Larson, Eric D. and Williams, Robert H., "Advanced Gasification-Based Biomass Power Generation and Cogeneration," prepared for ESETT "91, October 21-25, 1991.

Das, Aqua and Reed, Thomas B., Handbook of Biomass Downdraft Gasifier Engine Systems, Solar Energy Research Institute, March, 1988.

Larson, Eric D., A Developing-Country-Oriented Overview of Technologies and Costs for Converting Biomass Feedstocks into Gases, Liquids, and Electricity, The Center for Energy and Environmental Studies, Princeton University, November, 1991.

Bodlund, Birgit, Williams, Robert H., and Johansson, Editors, Efficient End-Use and New Generation Technologies, and Their Planning Implications, "Biomass Gasification for Gas Turbine Power Generation," Lund University Press, pp. 697-738.

Bridgewater, A-V., Buekens, A.G., et.al., Commercial and Marketing Aspects of Gasifiers, Commission of the European Communities, Luxembourg Office for Official Publications of the European Communities, 1990.

Larson, E.D., and Williams, R.H., "Biomass-Gasifier Steam-Injected Gas Turbine Cogeneration," Journal of Engineering for Gas Turbines and Power, Vol. 112, April 1990.

Krass, Donald L., Editor, Energy From Biomass and Wastes XIV, Institute of Gas Technology, Chicago, IL, 1991.

Larson, E.D., "Biomass-Gasifier/Gas Turbine Cogeneration in the Pulp and Paper Industry," presented at the International Gas Turbine and Aeroengine Congress and Exposition, Orlando, FL, June 3-6, 1992.

Durai-Swamy, K., Houck, Prent C., Feng, Qiao D., "Production of Clean Medium Btu Gas from Gasification of Sludge Wastes," Presentation at 202nd American Chemical Society National Meeting, New York, NY, August 25-30, 1991.

Larson, Eric D., et. al., "Biomass-Gasifier Steam-Injected Gas Turbine Cogeneration from the Sugar Cane Industry," Energy From Biomass and Wastes XIV, Institute of Gas Technology, Chicago, Il, 1991.

Larson, L.E., Rundstrom, D.A., "Operating Experience with a Wood Fueled Downdraft Gasifier at the Highgrove Generating Station," Presentation at the American Institute of Chemical Engineers Spring National Meeting, New Orleans, LA, March 6-10, 1988.

Ferrero, G.L., et. al., Editors, Pyrolysis and Gasification, Elsevier Applied Science, London and New York, 1989.

Newhall, J., Taylor, G., Folsom, B., "Waste Combustion System Analysis," EPA-600/7-91-008, USEPA, Research Triangle Park, NC, December 1991.

Larson, Eric D., Katofsky, Ryan E., "Production of Hydrogen and Methanol Via Biomass Gasification," to appear in Advances in Thermochemical Biomass Conversion, Elsevier Applied Science, London, 1992.

Coal Processing Technology, Volume VI, Prepared by Editors of Chemical Engineering Progress, American Institute of Chemical Engineers, New York, 1980.

Atkins, R.S., Donovan, C.T., Wood Products in the Waste Stream: Characterization and Combustion Emissions, New York State Research and Development Authority, Contract No. 1531-ERERER-91, November 1992. 
Oglesby, H.S. and Blosser, R.O., "Information on the Sulfur Content of Bark and its Contribution to $\mathrm{SO}_{2}$ Emissions when Burned as a Fuel," Journal of the Air Pollution Control Association, Volume 30, No. 7, July 1980.

Kaiser, Elmer R., "The Sulfur Balance of Incinerators," Journal of the Air Pollution Control Association, Volume 18, No. 3, March 1968.

Abbasian, Javad and Rehmat, Amir, "Reaction of Calcium-Based Sorbents with Sulfur Compounds During Gasification," Gas Research Institute, GRI-91-0396, December, 1991.

Kistler, R.C., Widmer, F., and Brunner, P.H., "Behavior of Chromium, Nickel, Copper, Zinc, Cadmium, Mercury, and Lead during the Pyrolysis of Sewage Sludge," Environmental Science Technology, Volume 21, No. 7, 1987.

Weast, Robert C., Editor-in-Chief, CRC Handbook of Chemistry and Physics, 65th Edition, CRC Press, Inc., Boca Raton, Florida, 1985. 
Appendix A

Economic Calculations 


\section{NYSERDA Gasifier Economic study INPUT SECTION}

\begin{tabular}{|c|c|c|c|c|c|c|}
\hline \multirow{2}{*}{ OWER PRODUCTION } & \multicolumn{3}{|c|}{$3 \mathrm{MW}$} & \multicolumn{3}{|c|}{$30 \mathrm{MW}$} \\
\hline & CASE 1 & CASE 2 & CASE 3 & CASE 4 & CASE 5 & CASE 6 \\
\hline HOURS OF OPERATION/YEAR & 7500 & 7500 & 7500 & 8000 & 8000 & 8000 \\
\hline GROSS POWER OUTPUT, MW & 3 & 3 & 3 & 30 & 30 & 30 \\
\hline $\begin{array}{l}\text { PLANT POWER REQUIREMENTS, MW (1) } \\
\text { ENERGY SALES TO UTILTY, MW }\end{array}$ & $\begin{array}{r}0.3 \\
2\end{array}$ & $\begin{array}{r}0.3 \\
2\end{array}$ & $\begin{array}{r}0.3 \\
2\end{array}$ & $\begin{array}{r}3 \\
27\end{array}$ & $\begin{array}{r}3 \\
27\end{array}$ & $\begin{array}{r}3 \\
27\end{array}$ \\
\hline BALANCE AVAILABLE FOR RETAIL OFFSET, MW (2) & 0.7 & 0.7 & $0 . \overline{7}$ & 0 & 0 & 0 \\
\hline TONS WOOD CHIP CONSUMED/HOUR & 11.4 & 3.5 & 3.626 & 56.58 & 33 & 31.41 \\
\hline
\end{tabular}

\begin{tabular}{|c|c|c|c|c|c|c|}
\hline PERATING \& MAINTENANCE EXPENSES & CASE 1 & $\begin{array}{c}3 \mathrm{MW} \\
\text { CASE } 2\end{array}$ & CASE 3 & CASE 4 & $\begin{array}{l}\text { 30MW } \\
\text { CASE } 5\end{array}$ & CASE 6 \\
\hline ASH DISPOSAL COSTS, \$/TON & $\$ 45$ & $\$ 45$ & $\$ 45$ & $\$ 38$ & $\$ 38$ & $\$ 38$ \\
\hline PERCENT ASH & $5 \%$ & $3 \%$ & $5 \%$ & $5 \%$ & $3 \%$ & $5 \%$ \\
\hline \$YYEAR ASH DISPOSAL - calculated & $\$ 192,375$ & $\$ 35,438$ & $\$ 61,189$ & $\$ 860,016$ & $\$ 331,056$ & $\$ 477,432$ \\
\hline WATER AND SEWER FEES, SYYR & $\$ 83,000$ & $\$ 83.000$ & $\$ 83,000$ & $\$ 830,000$ & $\$ 830,000$ & $\$ 830,000$ \\
\hline LABORATORY ANALYSIS, \$NR & $\$ 25,000$ & $\$ 25,000$ & $\$ 25,000$ & $\$ 25,000$ & $\$ 25,000$ & $\$ 25,000$ \\
\hline PURCHASED FUEL COST, \$/TON WOOD CHIPS & \$o & \$o & \$o & $\$ 17$ & $\$ 17$ & $\$ 17$ \\
\hline \$NEAR WOOD CHIPS - calculated & \$o & $\$ 0$ & \$o & $\$ 7,694,880$ & $\$ 4,488,000$ & $\$ 4,271,760$ \\
\hline PERSONNEL, including administration & $\$ 360,000$ & $\$ 360,000$ & $\$ 360,000$ & $\$ 900,000$ & $\$ 900,000$ & $\$ 900,000$ \\
\hline SPARE PARTS \& CONSUMABLES & $\$ 271,456$ & $\$ 244,800$ & $\$ 151,776$ & $\$ 1,247,200$ & $\$ 1,373,600$ & $\$ 995,520$ \\
\hline REPAIRS/CONTRACTLABOR & $\$ 203,592$ & $\$ 183,600$ & $\$ 113,832$ & $\$ 935,400$ & $\$ 1.030,200$ & $\$ 746,640$ \\
\hline MAJOR OVERHAUL RESERVE & $\$ 101,796$ & $\$ 91,800$ & $\$ 56,916$ & $\$ 467,700$ & $\$ 515,100$ & $\$ 373,320$ \\
\hline INSURANCE & $\$ 67.864$ & $\$ 61,200$ & $\$ 37,944$ & $\$ 311.800$ & $\$ 343,400$ & $\$ 248,880$ \\
\hline OTHEA & \$o & $\$ 0$ & $\$ 0$ & so & $\$ 0$ & $\$ 0$ \\
\hline OTALO \& $\mathrm{M}$ & $\$ 1,305,083$ & $\$ 1,084,838$ & $\$ 889,657$ & $\$ 13,271,996$ & $\$ 9,836,356$ & $\$ 8,868,552$ \\
\hline Annual Escalating Factor & $3 \%$ & $3 \%$ & $3 \%$ & $3 \%$ & $3 \%$ & $3 \%$ \\
\hline
\end{tabular}

\begin{tabular}{|c|c|c|c|c|c|c|}
\hline \multirow[t]{2}{*}{ EVENUES } & \multicolumn{3}{|c|}{$3 \mathrm{Mw}$} & \multicolumn{3}{|c|}{$30 \mathrm{MW}$} \\
\hline & CASE 1 & CASE 2 & CASE 3 & CASE 4 & CASE 5 & CASE 6 \\
\hline ENERGY SALES TO UTILITY, \$/KWH (evelized rate) & 0.0817 & 0.0817 & 0.0817 & 0.14 & 0.14 & 0.14 \\
\hline RETAIL ELECTRIC PURCHASE RATE \$/KWH (ब) & 0.14 & 0.14 & 0.14 & 0.14 & 0.14 & 0.14 \\
\hline TIPPING FEES \$/ton & $\$ 30$ & $\$ 30$ & $\$ 30$ & $\$ 0$ & $\$ 0$ & \$o \\
\hline
\end{tabular}

\begin{tabular}{|c|c|c|c|c|c|c|}
\hline \multirow[t]{2}{*}{ NANCINGITAX ASSUMPTIONS } & \multicolumn{3}{|c|}{$3 \mathrm{Mw}$} & \multicolumn{3}{|c|}{$30 \mathrm{Mw}$} \\
\hline & CASE 1 & CASE 2 & CASE 3 & CASE 4 & CASE 5 & CASE 6 \\
\hline \multicolumn{7}{|l|}{ AXES } \\
\hline STATE + LOCAL $\%$ OF TAXA & $9 \%$ & $9 \%$ & $9 \%$ & $9 \%$ & $9 \%$ & $9 \%$ \\
\hline FEDERAL, $\%$ OF TAXABLE INCOME & $34 \%$ & $34 \%$ & $34 \%$ & $34 \%$ & $34 \%$ & $34 \%$ \\
\hline TAX CAEDIT, BIO ENERGY SOURCE & $0 \%$ & $0 \%$ & $0 \%$ & $0 \%$ & $0 \%$ & $0 \%$ \\
\hline XED CAPITAL INVESTMENT & $\$ 6,786,400$ & $\$ 6,120,000$ & $\$ 3,794,400$ & $\$ 31,180,000$ & $\$ 34,340,000$ & $\$ 24,888,000$ \\
\hline DTAL CAPITAL INVESTMENT & $\$ 7,465,040$ & $\$ 6,732,000$ & $\$ 4,173,840$ & $\$ 34,298,000$ & $\$ 37,774,000$ & $\$ 27,376,800$ \\
\hline EBT PERCENT & $75 \%$ & $75 \%$ & $75 \%$ & $75 \%$ & $75 \%$ & $75 \%$ \\
\hline QUITY PERCENT & $25 \%$ & $25 \%$ & $25 \%$ & $25 \%$ & $25 \%$ & $25 \%$ \\
\hline EBT AMOUNT (total capital investm & $\$ 5,598,780$ & $\$ 6,715,170$ & $\$ 4,163,405$ & $\$ 34,212,255$ & $\$ 37,679,565$ & $\$ 27,308,358$ \\
\hline EBT TERM (assumed equal to life of plent) & 30 & & & & & \\
\hline NNUAL INTEREST RATE & $10.0 \%$ & $10.0 \%$ & $10.0 \%$ & $10.0 \%$ & $10.0 \%$ & $10.0 \%$ \\
\hline EPRECIATION is straight-line & $\$ 223,951$ & $\$ 201,960$ & $\$ 125,215$ & $\$ 1,028,940$ & $\$ 1,133,220$ & $\$ 821,304$ \\
\hline ALVAGE VALUE (assumed $1 \%$ of Fixed Capital) & $\$ 67,864$ & $\$ 61,200$ & $\$ 37,944$ & $\$ 311,800$ & $\$ 343,400$ & $\$ 248,880$ \\
\hline
\end{tabular}

les:

Estimated electrical power requirements of generating plant. Assumed to be 10 percent of gross output.

Available power that can be used to supply other on-site operations in lieu of purchasing power from the utility.

Used for calculating the value of on-site generated power used in place of purchased utility power. 


\section{TOTAL CAPITAL INVESTMENT}

NYSERDA Gasifier Economic study

\begin{tabular}{|c|c|}
\hline $\begin{array}{c}\text { Gasifier - Steam Turbine } \\
\text { 3Mw gross capacity }\end{array}$ & \\
\hline I. DIRECT COSTS & \\
\hline Fluid Bed Gasifier & $\$ 790,000$ \\
\hline Turbine Generator & $\$ 1,500,000$ \\
\hline Boiler & $\$ 800,000$ \\
\hline Low Btu Gas Burner & $\$ 100,000$ \\
\hline Cooling Tower & $\$ 200,000$ \\
\hline Baghouse & $\$ 250,000$ \\
\hline Fuel and Ash Handling Equipment & $\$ 500,000$ \\
\hline Balance of Plant & $\$ 850,000$ \\
\hline Subtotal $=$ & $\$ 4,990,000$ \\
\hline II. INDIRECT COSTS & \\
\hline A. Engineering and Supervision & $\$ 399,200$ \\
\hline B. Construction Expense, Contractor's Fee & $\$ 748,500$ \\
\hline C. Permits & $\$ 149,700$ \\
\hline D. Contingency & $\$ 499,000$ \\
\hline Subtotal $=$ & $\$ 1,796,400$ \\
\hline $\begin{array}{l}\text { III. FIXED CAPITALINVESTMENT }(I+I I) \\
\text { IV. WORKING CAPITAL (10\% OF FCI) } \\
\text { V. TOTAL CAPITALINVESTMENT }\end{array}$ & $\begin{array}{r}\$ 6,786,400 \\
\$ 678,640 \\
\$ 7,465,040\end{array}$ \\
\hline
\end{tabular}

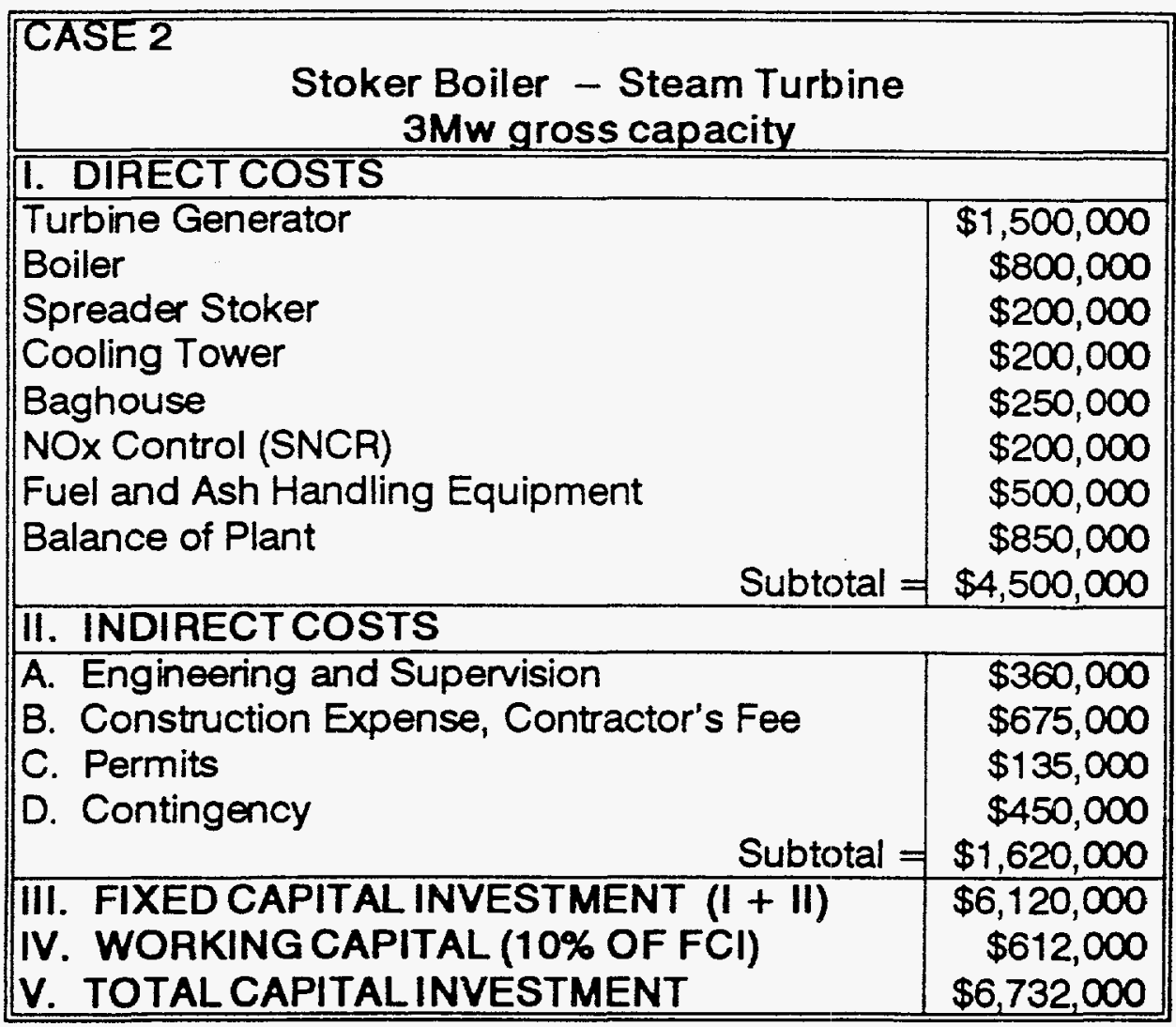




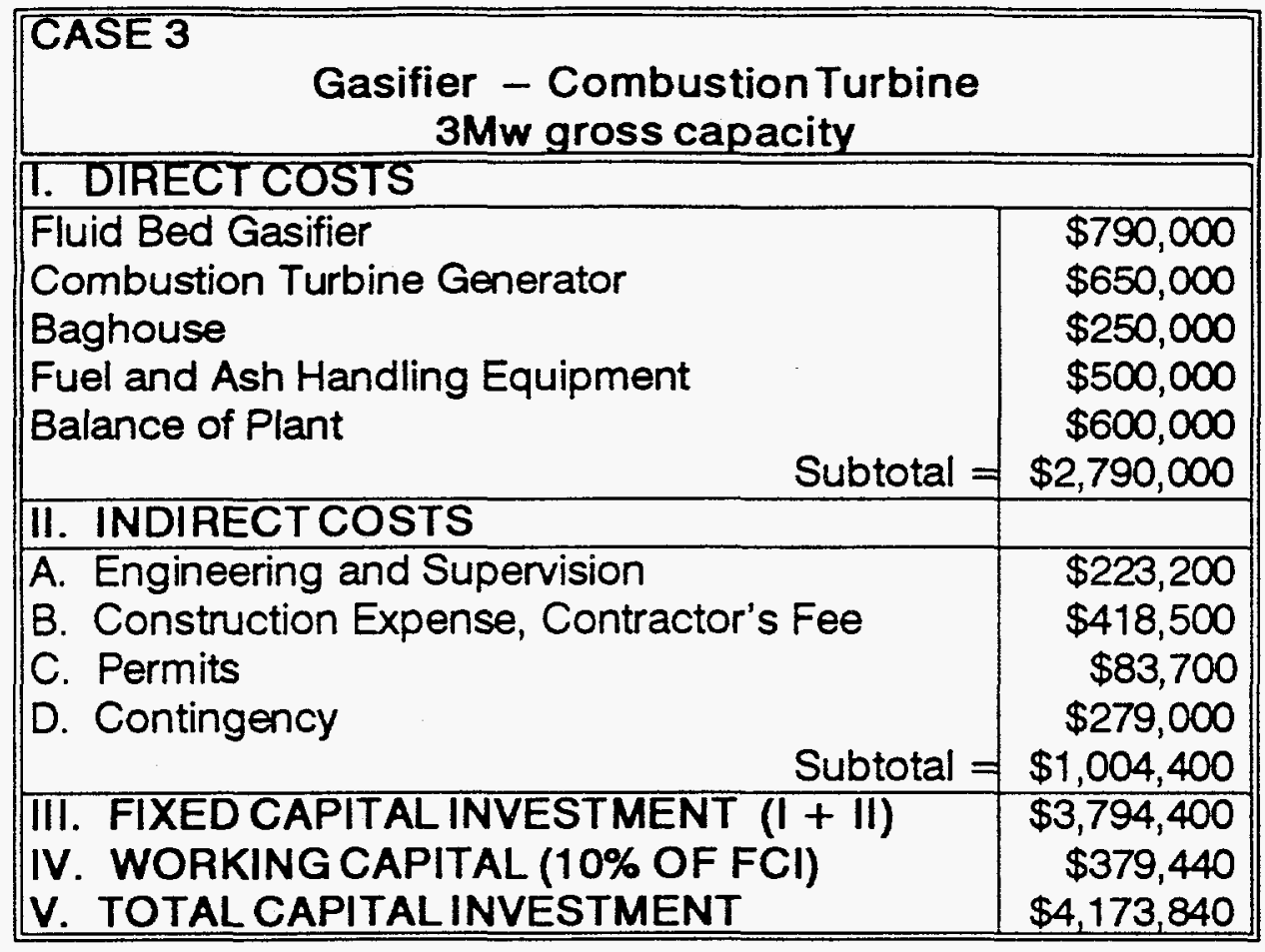

\begin{tabular}{|c|c|}
\hline $\begin{array}{c}\text { Gasifier - Steam Turbine } \\
30 \mathrm{Mw} \text { gross capacity }\end{array}$ & \\
\hline I. DIRECT COSTS & \\
\hline Fluid Bed Gasifier & $\$ 1,300,000$ \\
\hline Turbine Generator & $\$ 7,000,000$ \\
\hline Boiler & $\$ 4,000,000$ \\
\hline Low Btu Gas Burner & $\$ 500,000$ \\
\hline Cooling Tower & $\$ 1,500,000$ \\
\hline Fuel and Ash Handling Equipment & $\$ 5,000,000$ \\
\hline Baghouse & $\$ 1,000,000$ \\
\hline Balance of Plant & $\$ 8,000,000$ \\
\hline Subtot & $\$ 28,300,000$ \\
\hline II. INDIRECT COSTS & \\
\hline A. Engineering and Supervision & $\$ 640,000$ \\
\hline B. Construction Expense, Contractor's Fee & $\$ 1,200,000$ \\
\hline C. Permits & $\$ 240,000$ \\
\hline D. Contingency & $\$ 800,000$ \\
\hline Subtot & $\$ 2,880,000$ \\
\hline 111. FIXED CAPITAL INVESTMENT $(1+I)$ & $\$ 31,180,000$ \\
\hline IV. WORKING CAPITAL (10\% OF FCI) & $\$ 3,118,000$ \\
\hline & $\$ 34,298,000$ \\
\hline
\end{tabular}




\begin{tabular}{|c|c|}
\hline \multicolumn{2}{|l|}{$\begin{array}{c}\text { Stoker Boiler - Steam Turbine } \\
30 \mathrm{Mw} \text { gross capacity }\end{array}$} \\
\hline \multicolumn{2}{|l|}{ 1. DIRECTCOSTS } \\
\hline Turbine Generator & $\$ 4,500,000$ \\
\hline Boiler & $\$ 5,000,000$ \\
\hline Spreader Stoker & $\$ 2,000,000$ \\
\hline Cooling Tower & $\$ 1,500,000$ \\
\hline Baghouse & $\$ 1,000,000$ \\
\hline NOx Control (SNCR) & $\$ 750,000$ \\
\hline Fuel and Ash Handling Equipment & $\$ 2,000,000$ \\
\hline Balance of Plant & $\$ 8,500,000$ \\
\hline \multicolumn{2}{|c|}{ Subtotal $=\$ 25,250,000$} \\
\hline \multicolumn{2}{|l|}{ II. INDIRECTCOSTS } \\
\hline A. Engineering and Supervision & $\$ 2,020,000$ \\
\hline B. Construction Expense, Contractor's Fee & $\$ 3,787,500$ \\
\hline C. Permits & $\$ 757,500$ \\
\hline D. Contingency & $\$ 2,525,000$ \\
\hline Subtotal $=$ & $\$ 9,090,000$ \\
\hline III. FIXED CAPITALINVESTMENT $(I+I I)$ & $\$ 34,340,000$ \\
\hline IV. WORKING CAPITAL (10\% OF FCI) & $\$ 3,434,000$ \\
\hline V. TOTAL CAPITALINVESTMENT & $\$ 37,774,000$ \\
\hline
\end{tabular}

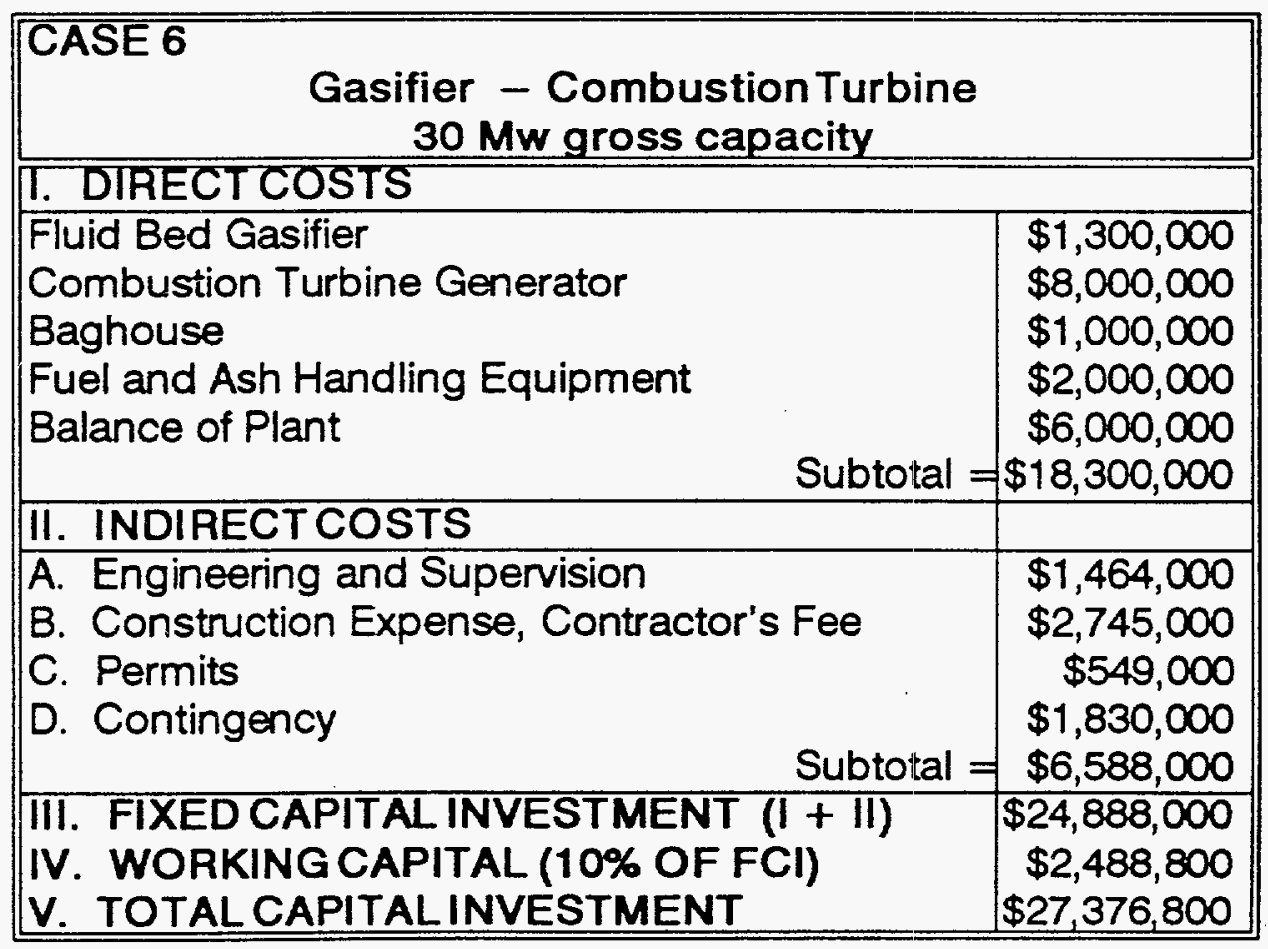




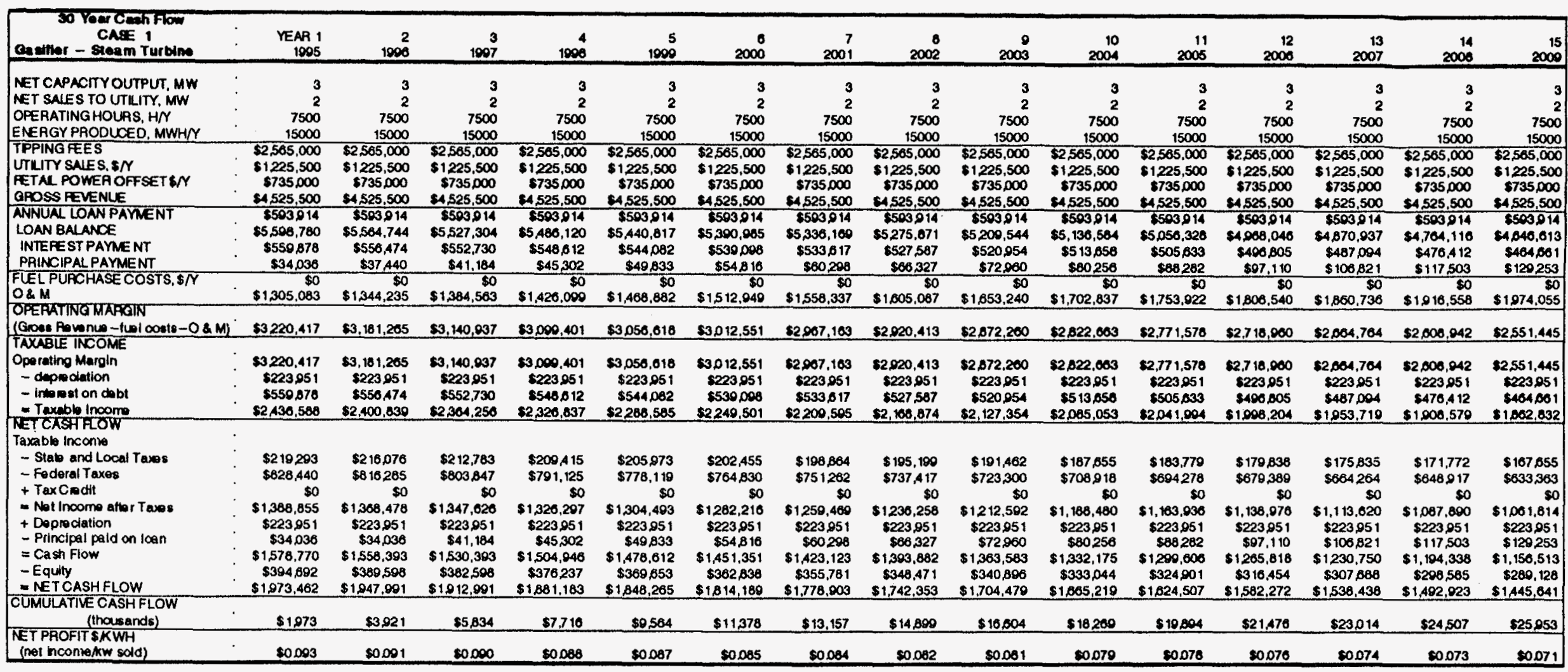




\begin{tabular}{|c|c|c|c|c|c|c|c|c|c|c|c|c|c|c|c|}
\hline 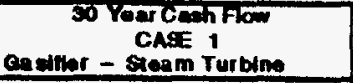 & $\begin{array}{r}\text { YEAP } 10 \\
2010\end{array}$ & 2011 & $\begin{array}{r}10 \\
2012 \\
\end{array}$ & $\begin{array}{r}19 \\
2013 \\
\end{array}$ & $\begin{array}{r}20 \\
2014\end{array}$ & $\begin{array}{r}21 \\
2015 \\
\end{array}$ & $\begin{array}{r}22 \\
2010 \\
\end{array}$ & $\begin{array}{r}23 \\
2017 \\
\end{array}$ & $\begin{array}{r}24 \\
2010\end{array}$ & $\begin{array}{r}25 \\
2010 \\
\end{array}$ & $\begin{array}{r}20 \\
2020\end{array}$ & $\begin{array}{r}27 \\
2021\end{array}$ & 2028 & 20023 & $\begin{array}{r}30 \\
2024\end{array}$ \\
\hline $\begin{array}{l}\text { NET CAPACITYOUTPUT, MW } \\
\text { NET SALES TO UTUIT, MWW } \\
\text { OPERATING HOUAS, HN } \\
\text { ENERGY PRODUCED, MWHN }\end{array}$ & $\begin{array}{r}3 \\
2 \\
7500 \\
15000\end{array}$ & $\begin{array}{r}3 \\
2 \\
7500 \\
15000\end{array}$ & $\begin{array}{r}3 \\
2 \\
7500 \\
15000\end{array}$ & $\begin{array}{r}3 \\
2 \\
7500 \\
15000\end{array}$ & $\begin{array}{r}3 \\
2 \\
7500 \\
15000\end{array}$ & $\begin{array}{r}3 \\
2 \\
7500 \\
15000\end{array}$ & $\begin{array}{r}3 \\
2 \\
7500 \\
15000\end{array}$ & $\begin{array}{r}3 \\
2 \\
7500 \\
15000\end{array}$ & $\begin{array}{r}3 \\
2 \\
7500 \\
15000\end{array}$ & $\begin{array}{r}3 \\
2 \\
7500 \\
15000\end{array}$ & $\begin{array}{r}3 \\
2 \\
7500 \\
15000\end{array}$ & $\begin{array}{r}3 \\
2 \\
7500 \\
15000\end{array}$ & $\begin{array}{r}3 \\
2 \\
7500 \\
15000\end{array}$ & $\begin{array}{r}3 \\
2 \\
7500 \\
15000\end{array}$ & $\begin{array}{r}3 \\
2 \\
7500 \\
15000\end{array}$ \\
\hline TPPING FEES & 585,000 & 505,000 & 565,000 & 505,000 & $\$ 2,565,000$ & $\$ 2,565,000$ & $\$ 2,565,000$ & 2565,000 & $2,565,000$ & 2565,000 & $\$ 2,565,000$ & $5,565,000$ & $\frac{10000}{5,05,000}$ & 2565,000 & 2565,000 \\
\hline $\begin{array}{l}\text { UTUITY SALS, SN } \\
\text { FETAL POWEROFFSET WN } \\
\text { GROSS PEVENLE }\end{array}$ & $\begin{array}{r}\$ 1,225,500 \\
\$ 7355000 \\
\$ 4,525,500 \\
\end{array}$ & $\begin{array}{r}\$ 1225,500 \\
\$ 735,000 \\
\$ 4,525,500 \\
\end{array}$ & $\begin{array}{r}\$ 1225.500 \\
\$ 735500 \\
\$ 4,525.500 \\
\end{array}$ & $\begin{array}{r}\$ 1225,500 \\
\$ 735000 \\
\$ 4,525,500 \\
\end{array}$ & $\begin{array}{r}\$ 1225,500 \\
\$ 735,000 \\
\$ 4,525,500 \\
\end{array}$ & $\begin{array}{r}\$ 1,225,500 \\
\$ 7355000 \\
\$ 4,525,500 \\
\end{array}$ & $\begin{array}{r}\$ 1,225,500 \\
\$ 735,000 \\
\$ 4,525,500 \\
\end{array}$ & $\begin{array}{r}\$ 1225,500 \\
\$ 735,000 \\
\$ 4,525,500 \\
\end{array}$ & $\begin{array}{r}\$ 1225,500 \\
\$ 735000 \\
\$ 4,525,500 \\
\end{array}$ & $\begin{array}{r}\$ 1225,500 \\
\$ 735,000 \\
\$ 4,525,500 \\
\end{array}$ & $\begin{array}{r}\$ 1225,500 \\
\$ 735,000 \\
\$ 4,525,500 \\
\end{array}$ & $\begin{array}{r}\$ 1225,500 \\
8735,000 \\
84,525,500 \\
\end{array}$ & $\begin{array}{r}\$ 1225,500 \\
\$ 735,000 \\
\$ 4,525,500 \\
\end{array}$ & $\begin{array}{r}\$ 1225.500 \\
\$ 735000 \\
\$ 4525,500 \\
\end{array}$ & $\begin{array}{r}\$ 1225,500 \\
\$ 7735,000 \\
4,525,500 \\
\end{array}$ \\
\hline ANNUAL LOAN PAYMENT & $\$ 503,014$ & 6503214 & $\$ 503.914$ & $\$ 503914$ & $\$ 503914$ & 8503914 & 8503014 & $\$ 503.014$ & 014 & 6503.914 & $\$ 503914$ & 5500,214 & $\$ 503914$ & 1014 & $\$ 503214$ \\
\hline $\begin{array}{l}\text { LOAN BALANCE } \\
\text { INTERE ST PAYMENT } \\
\text { PRINCIPAL PAYMENT }\end{array}$ & $\begin{array}{r}\$ 4 \$ 17,360 \\
\$ 451,730 \\
\$ 142,178\end{array}$ & $\begin{array}{r}\$ 4375,182 \\
\$ 437,518 \\
\$ 156,306\end{array}$ & $\begin{array}{r}\$ 4218,785 \\
\$ 421,870 \\
\$ 172,036\end{array}$ & $\begin{array}{r}\$ 4040,750 \\
\$ 404,675 \\
\$ 189230\end{array}$ & $\begin{array}{r}\$ 3857,510 \\
\$ 385,751 \\
\$ 208,163\end{array}$ & $\begin{array}{r}\$ 3,049,347 \\
\$ 364,935 \\
\$ 228,280\end{array}$ & $\begin{array}{r}\$ 3,420,367 \\
\$ 342,037 \\
\$ 251,878\end{array}$ & $\begin{array}{r}\$ 3,168,480 \\
\$ 318,849 \\
\$ 277,085\end{array}$ & $\begin{array}{r}\$ 2,801,424 \\
\$ 289,142 \\
\$ 304,772\end{array}$ & $\begin{array}{r}\$ 2,580,052 \\
\$ 258,005 \\
\$ 335,240\end{array}$ & $\begin{array}{r}\$ 2251,403 \\
\$ 225,140 \\
\$ 368,774\end{array}$ & $\begin{array}{r}\$ 1,882,029 \\
\$ 189,263 \\
\$ 105,652\end{array}$ & $\begin{array}{r}\$ 1470,977 \\
\$ 147000 \\
\$ 440217\end{array}$ & $\begin{array}{l}\$ 1030,700 \\
\$ 103,076 \\
\$ 400,838\end{array}$ & $\begin{array}{l}\$ 530,022 \\
\$ 55,002 \\
\$ 539,022\end{array}$ \\
\hline $\begin{array}{l}\text { FUEL PUACHASE COSTS, } N \\
\text { O\& } M\end{array}$ & $\begin{array}{r}\$ 14,180 \\
\$ 2,033,277\end{array}$ & $\begin{array}{r}\$ 100, \$ 0 \\
\$ 2.094,275 \\
\end{array}$ & $\begin{array}{r}\$ 0 \\
\$ 2.157 .103 \\
\end{array}$ & $\begin{array}{r}\$ \$ 0 \\
\$ 2,221,816 \\
\end{array}$ & $\begin{array}{r}\$ \$ 000 \\
\$ 2,288,471\end{array}$ & $\begin{array}{r}\$ \$ 357.125 \\
\$ 2.30\end{array}$ & $\begin{array}{r}50 \\
\$ 2 A 27.839 \\
500\end{array}$ & $\begin{array}{r}\$ 0 \\
\$ 2,500,674 \\
\end{array}$ & $\begin{array}{r}\$ 0 \\
\$ 2.575 .094 \\
\end{array}$ & $\begin{array}{r}\$ 2,50 \\
\$ 2,652,065 \\
\end{array}$ & $\begin{array}{r}\$ 00 \\
\$ 2,732.554 \\
500\end{array}$ & $\begin{array}{r}5000 \\
\$ 2,814,531\end{array}$ & $\begin{array}{r}\$ 10 \\
\$ 2,890,967 \\
\end{array}$ & $\begin{array}{r}\$ 0 \\
\$ 2.085 .036\end{array}$ & $\begin{array}{r}\$ 075.514 \\
\$ 070\end{array}$ \\
\hline 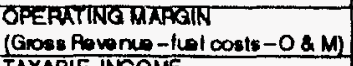 & $\$ 2,402,223$ & 25 & 397 & 304 & $=$ & $.168,375$ & 01 & 20 & $\infty$ & 35 & 40 & 000 & & & 200 \\
\hline 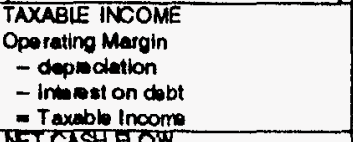 & $\begin{array}{r}\$ 2,402.223 \\
\$ 223.951 \\
\$ 451,736 \\
\$ 1816.536 \\
\end{array}$ & $\begin{array}{r}\$ 2,431,225 \\
8223.251 \\
8437,510 \\
\$ 1,769,750 \\
\end{array}$ & $\begin{array}{r}\$ 2,300,397 \\
\$ 223,951 \\
\$ 421,179 \\
\$ 1,722,507 \\
\end{array}$ & $\begin{array}{r}\$ 2,303,084 \\
6223,051 \\
\$ 404,075 \\
\$ 1075,057 \\
\end{array}$ & $\begin{array}{r}\$ 2237,029 \\
\$ 223.951 \\
\$ 3255,751 \\
\$ 1,027,327 \\
\end{array}$ & $\begin{array}{r}\$ 2,160,375 \\
\$ 223,051 \\
5354035 \\
51,570,400 \\
\end{array}$ & $\begin{array}{r}\$ 2,097,001 \\
\$ 223,951 \\
\$ 342,037 \\
\$ 1,531,073 \\
\end{array}$ & $\begin{array}{r}\$ 2,024,826 \\
82233051 \\
53108489 \\
\$ 1,484,020 \\
\end{array}$ & $\begin{array}{r}\$ 1949,800 \\
\$ 223,951 \\
\$ 28,412 \\
\$ 1,436,712 \\
\end{array}$ & $\begin{array}{r}\$ 1972.535 \\
\$ 223.951 \\
\$ 250.005 \\
\$ 1,300,010 \\
\end{array}$ & $\begin{array}{r}\$ 1,792,940 \\
8223,951 \\
\$ 2225,140 \\
81,343,055 \\
\end{array}$ & $\begin{array}{r}\$ 1,710,800 \\
\$ 223,851 \\
\$ 1002,203 \\
\$ 1200,755 \\
\end{array}$ & $\begin{array}{r}\$ 1020.533 \\
5223.951 \\
\$ 147009 \\
\$ 1254,005 \\
\end{array}$ & $\begin{array}{r}\$ 1,530.504 \\
\$ 223.351 \\
\$ 103,070 \\
\$ 1212.537 \\
\end{array}$ & $\begin{array}{r}\$ 1,440,900 \\
\$ 223.951 \\
853,002 \\
\$ 1,172,043 \\
\end{array}$ \\
\hline Taxable Inca & & & & & & & & & & & & & & & \\
\hline $\begin{array}{l}\text { - Stav and Local Taras } \\
\text { - Federal Taxes }\end{array}$ & $\begin{array}{l}\$ 163,480 \\
\$ 617,622\end{array}$ & $\begin{array}{l}\$ 159,278 \\
\$ 601,717\end{array}$ & $\begin{array}{l}\$ 155,031 \\
\$ 585,673\end{array}$ & $\begin{array}{l}\$ 150,755 \\
\$ 569.520\end{array}$ & $\begin{array}{l}\$ 146,459 \\
\$ 553291\end{array}$ & $\begin{array}{l}\$ 142,154 \\
\$ 537026\end{array}$ & $\begin{array}{l}\$ 137,851 \\
\$ 520,769\end{array}$ & $\begin{array}{l}\$ 133,562 \\
\$ 504,569\end{array}$ & $\begin{array}{l}\$ 129,304 \\
\$ 488,482\end{array}$ & $\begin{array}{l}\$ 125,003 \\
\$ 472,572\end{array}$ & $\begin{array}{l}\$ 120947 \\
\$ 456911\end{array}$ & $\begin{array}{l}\$ 110,888 \\
\$ 441,577\end{array}$ & $\begin{array}{l}\$ 112,040 \\
\$ 426861\end{array}$ & $\begin{array}{l}\$ 100,128 \\
\$ 412,263\end{array}$ & $\begin{array}{l}\$ 105,494 \\
\$ 398, A 95\end{array}$ \\
\hline $\begin{array}{l}+ \text { Tax Codth } \\
\text { - Not Income ofter T }\end{array}$ & & & & & & $\begin{array}{r}50 \\
\$ 900300\end{array}$ & $\begin{array}{r}\$ 0 \\
5873054\end{array}$ & & $\begin{array}{r}50 \\
5018028\end{array}$ & $\begin{array}{r}80 \\
8702254\end{array}$ & $\begin{array}{r}\$ 0 \\
8705907\end{array}$ & $\begin{array}{r}60 \\
5740291\end{array}$ & $\begin{array}{r}50 \\
5284\end{array}$ & $\begin{array}{r}\$ 0 \\
\$ 0091,146\end{array}$ & $\begin{array}{r}50 \\
\operatorname{sos} 005\end{array}$ \\
\hline $\begin{array}{l}\text { - Not income after Taves } \\
\text { + Doprociation }\end{array}$ & $\begin{array}{l}\$ 1,035,428 \\
\$ 223,951\end{array}$ & $\begin{array}{l}\$ 1,008,761 \\
\$ 223,051\end{array}$ & $\begin{array}{r}5081,363 \\
\$ 223,251\end{array}$ & $\begin{array}{l}\$ 954,783 \\
\$ 223,951\end{array}$ & $\begin{array}{l}\$ \$ 27.570 \\
\$ 223.951\end{array}$ & & & $\begin{array}{l}\$ 845,895 \\
\$ 223,951\end{array}$ & & & & & & & $\$ 223.051$ \\
\hline $\begin{array}{l}\text { - Principal pe } \\
\text { = Cash Flow }\end{array}$ & & & $\$ 172,336$ & & & & & & & & & & & & $\$ 530,022$ \\
\hline$=$ Cash Flow & & $\$ 1,076,316$ & 1033,779 & $\$ 980,494$ & $\$ 043,364$ & $\$ 895280$ & $\$ 845,127$ & & 105 & & & & & & $\$ 352004$ \\
\hline $\begin{array}{l}\text { - Equity } \\
\text { = NETCASH FLOW }\end{array}$ & $\begin{array}{r}\$ 279,300 \\
\$ 1,390,498\end{array}$ & $\begin{array}{r}\$ 289070 \\
\$ 1,345,395\end{array}$ & $\begin{array}{r}\$ 258,445 \\
\$ 1292,223\end{array}$ & $\begin{array}{r}\$ 247,374 \\
\$ 1,230,808\end{array}$ & $\begin{array}{r}\$ 235,841 \\
\$ 1,179,205\end{array}$ & $\begin{array}{r}\$ 223820 \\
\$ 1,119,100\end{array}$ & $\begin{array}{r}\$ 211,282 \\
\$ 1058,409\end{array}$ & $\begin{array}{l}\$ 198,195 \\
\$ 900,970\end{array}$ & $\begin{array}{l}\$ 184,526 \\
\$ 822,631\end{array}$ & $\begin{array}{l}\$ 170,230 \\
\$ 851,105\end{array}$ & $\begin{array}{l}\$ 155294 \\
\$ 776,408\end{array}$ & $\begin{array}{l}\$ 130,046 \\
\$ 000238\end{array}$ & $\begin{array}{l}\$ 123255 \\
\$ 010273\end{array}$ & $\begin{array}{l}\$ 108,065 \\
\$ 530,324\end{array}$ & $\begin{array}{r}\$ 023 \\
\$ 40.117\end{array}$ \\
\hline $\begin{array}{l}\text { CUMULATIVE CASHFLOW } \\
\text { (ithousands) }\end{array}$ & $\$ 27.349$ & 8,895 & 9.907 & 2224 & 2.403 & 3.522 & 4,570 & 35,569 & $\$ 36.492$ & 37343 & $\$ 28,120$ & $\$ 30,818$ & 30,434 & 60,005 & 40,405 \\
\hline $\begin{array}{l}\text { NET PROFIT SKWH } \\
\text { (not hcome, } k \text { w sold })\end{array}$ & 50.000 & $\$ 0.087$ & 50.005 & $\$ 0004$ & $\$ 0.062$ & $\$ 0.000$ & 50056 & 50.050 & $\$ 0055$ & $\$ 0.053$ & 20.051 & $\$ 0.040$ & $\infty 0048$ & 50.040 & 00045 \\
\hline
\end{tabular}




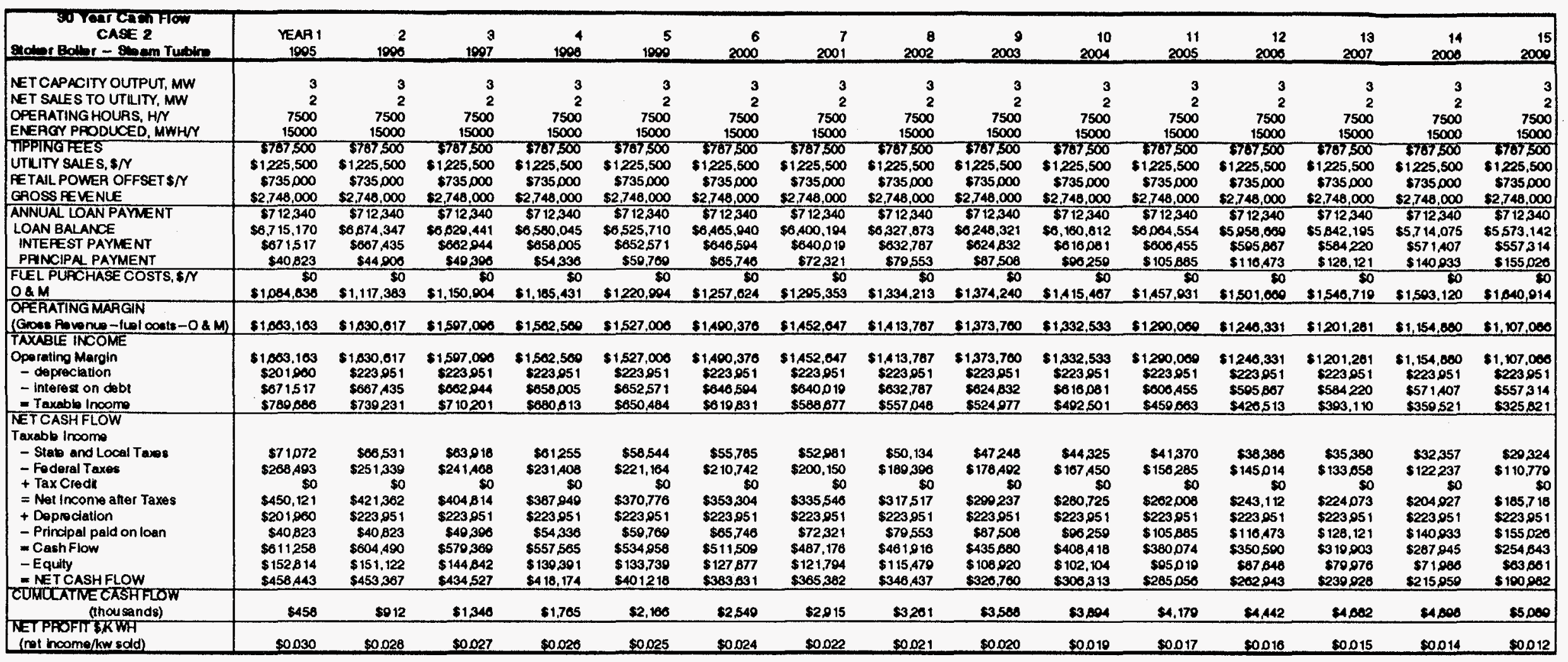




\begin{tabular}{|c|c|c|c|c|c|c|c|c|c|c|c|c|c|c|c|}
\hline 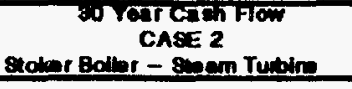 & $\begin{array}{r}\text { YEAP } 16 \\
2010 \\
\end{array}$ & $\begin{array}{r}17 \\
2011 \\
\end{array}$ & $\begin{array}{r}18 \\
2012 \\
\end{array}$ & $\begin{array}{r}19 \\
2013 \\
\end{array}$ & $\begin{array}{r}20 \\
2014 \\
\end{array}$ & $\begin{array}{r}21 \\
2015 \\
\end{array}$ & 222 & $\begin{array}{r}23 \\
2017 \\
\end{array}$ & $\begin{array}{r}24 \\
2010 \\
\end{array}$ & $\begin{array}{r}25 \\
2010 \\
\end{array}$ & $\begin{array}{r}26 \\
2020 \\
\end{array}$ & $\begin{array}{r}27 \\
2021 \\
\end{array}$ & $\begin{array}{r}28 \\
2022 \\
\end{array}$ & $\begin{array}{r}29 \\
2003 \\
\end{array}$ & 2024 \\
\hline NET CAPACITY OUTPUT, MW & 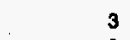 & 3 & 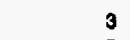 & 3 & 3 & 3 & 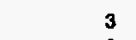 & 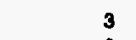 & 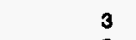 & $-2+3$ & 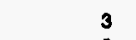 & 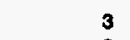 & 3 & 3 & \\
\hline & & & & & 2 & 2 & - & 2 & & & 2 & 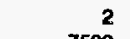 & 2 & 2 & \\
\hline $\begin{array}{l}\text { OPERATING HOUAS, HY } \\
\text { ENEROY PRODUCED, MWHY }\end{array}$ & $\begin{array}{r}7500 \\
15000\end{array}$ & $\begin{array}{r}7500 \\
15000\end{array}$ & $\begin{array}{r}7500 \\
15000\end{array}$ & $\begin{array}{r}7500 \\
15000\end{array}$ & $\begin{array}{r}7500 \\
15000\end{array}$ & $\begin{array}{r}7500 \\
15000\end{array}$ & $\begin{array}{r}7500 \\
15000\end{array}$ & $\begin{array}{r}7500 \\
15000\end{array}$ & $\begin{array}{r}7500 \\
15000\end{array}$ & $\begin{array}{r}7500 \\
15000\end{array}$ & $\begin{array}{r}7500 \\
15000\end{array}$ & $\begin{array}{r}7500 \\
15000\end{array}$ & $\begin{array}{r}7500 \\
15000\end{array}$ & $\begin{array}{r}7500 \\
15000\end{array}$ & $\begin{array}{r}7500 \\
15000\end{array}$ \\
\hline TPPPINOFES & $\$ 787,500$ & $\$ 787500$ & 5767500 & 5707,500 & $\$ 787,500$ & $\$ 787500$ & 5787500 & $\$ 707500$ & 8787500 & $\$ 787,500$ & 6787500 & 8767,500 & 3967500 & 5767500 & 3707500 \\
\hline UTuा & $\$ 1,225,500$ & $\$ 1225,500$ & $\$ 1,225,500$ & $\$ 1225,500$ & $\$ 1,225,500$ & 1225,500 & $1,225,500$ & 1225,500 & $1,225,500$ & 1225,500 & 1225,500 & $\$ 1,225,500$ & $\$ 1,225,500$ & $\$ 1225,500$ & $\$ 1225.500$ \\
\hline FETALLF & $\$ 735,000$ & $\$ 735,000$ & $\$ 735,000$ & $\$ 735000$ & $\$ 735000$ & & $\$ 735000$ & $\$ 735,000$ & $\$ 735,000$ & $\$ 735000$ & $\$ 735,000$ & $\begin{array}{l}8735,000 \\
2748,000\end{array}$ & & 0 & $\begin{array}{r}\$ 735,000 \\
82748,000\end{array}$ \\
\hline GRO & & $\$ 2,748,000$ & $\$ 2,748,000$ & $\$ 2,748,000$ & $\$ 2,748,000$ & $\infty$ & $\$ 2,748,000$ & $\$ 2,748,000$ & $\$ 2,7$ & $2,748,000$ & $\$ 2,748,000$ & $2,748,000$ & $\$ 2.7$ & $\infty 00$ & $\$ 2,748,000$ \\
\hline ANNUAL LOAN PAYMENT & $\$ 712,340$ & $\$ 712,340$ & $\$ 712,340$ & $\$ 712,340$ & $\$ 712,340$ & $\$ 712,340$ & $\$ 712,340$ & $\$ 712,340$ & $\$ 7712,340$ & $\$ 712,340$ & $\$ 712,340$ & $\$ 712,340$ & $\$ 712,340$ & $\$ 712,340$ & $\$ 712,340$ \\
\hline $\begin{array}{l}\text { LOAN BALANCE } \\
\text { INTEFEST PAYNENT }\end{array}$ & $\begin{array}{r}\$ 5,418,116 \\
\$ 541,812 \\
\$ 170570\end{array}$ & $\begin{array}{r}\$ 5,247,580 \\
\$ 524,759 \\
\$ 2147,581\end{array}$ & $\begin{array}{r}\$ 5,060,006 \\
\$ 506,001\end{array}$ & $\begin{array}{r}\$ 4,853,668 \\
\$ 485,367 \\
\$ 250,074\end{array}$ & $\begin{array}{r}\$ 4,626,693 \\
\$ 462,669 \\
\$ 240671\end{array}$ & $\begin{array}{r}\$ 4,377,022 \\
\$ 437,702\end{array}$ & $\begin{array}{l}\$ 4,102,384 \\
\$ 4102,236 \\
\$ 102\end{array}$ & $\begin{array}{r}\$ 3,800,282 \\
\$ 380,028 \\
\$ 332,312\end{array}$ & $\begin{array}{r}\$ 3467,970 \\
\$ 346,797\end{array}$ & $\begin{array}{r}\$ 3,102,427 \\
\$ 310,243 \\
\$ 002097\end{array}$ & $\begin{array}{r}\$ 2,700,330 \\
\$ 270,033 \\
\$ 442,307\end{array}$ & $\begin{array}{r}\$ 2,258,023 \\
\$ 225,002 \\
\$ 480,538\end{array}$ & $\begin{array}{r}\$ 1,771,485 \\
\$ 177,148 \\
\$ 535,192\end{array}$ & $\begin{array}{r}\$ 1,236,293 \\
\$ 123029 \\
\$ 588711\end{array}$ & $\begin{array}{r}\$ 047,582 \\
\$ 04,758 \\
5047,582\end{array}$ \\
\hline $\begin{array}{l}\text { PFANCIPAL PAYMENT } \\
\text { FLEL PUACHASE COSTS, \$N }\end{array}$ & $\frac{220}{\$ 0}$ & $\frac{581}{50}$ & $\frac{\$ 200340}{\$ 0}$ & $\frac{\$ 220.974}{50}$ & $\frac{\$ 249,871}{\$ 0}$ & $\frac{\$ 2 / 40036}{90}$ & $\frac{\$ 302,102}{\$ 0}$ & $\frac{\$ 332,312}{80}$ & $\frac{\$ 305,243}{80}$ & $\frac{-402,097}{80}$ & & $\frac{8400,350}{80}$ & $\frac{102}{50}$ & $\frac{8000,111}{60}$ & \\
\hline O\&M & 1000,141 & $\$ 1.740 .846$ & 1.793 .071 & 1.840 .003 & 902.200 & 959,337 & 018.117 & $\$ 2,078,001$ & $2,141,021$ & 205.251 & 2271,400 & $2.3309,551$ & 00,736 & 2.030 & 0.491 \\
\hline 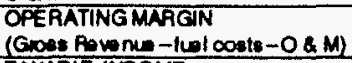 & 659 & 154 & 229 & 137 & 731 & 003 & 1003 & $\$ 000,330$ & $\$ 600,979$ & $\$ 542,740$ & $\$ 470.501$ & $\$ 00,400$ & 330,262 & $\$ 205970$ & $\$ 101,500$ \\
\hline TAXABLE INCOME & & & & & & & & & & & & & & & \\
\hline $\begin{array}{l}\text { Operating Margin } \\
\text { - depreclation } \\
\text { - interest on dabt } \\
\text { = Taxable Income }\end{array}$ & $\begin{array}{r}\$ 1.057,850 \\
\$ 223251 \\
\$ 541812\end{array}$ & $\begin{array}{r}\$ 1,007.154 \\
\$ 223.051 \\
\$ 524,759\end{array}$ & $\begin{array}{l}5 \$ 54,929 \\
\$ 223,951 \\
\$ 500,001\end{array}$ & $\begin{array}{l}\$ 001.137 \\
\$ 223.951 \\
\$ 485,307 \\
\$ 191819\end{array}$ & $\begin{array}{l}345,731 \\
223.951 \\
662000\end{array}$ & $\begin{array}{l}\$ 700.003 \\
\$ 223,251 \\
\$ 437,702 \\
\$ 127009\end{array}$ & $\begin{array}{l}\$ 720,083 \\
\$ 223,951 \\
\$ 410,238\end{array}$ & $\begin{array}{l}\$ 0603399 \\
\$ 223.951 \\
6380028\end{array}$ & $\begin{array}{l}\$ 000979 \\
\$ 223,951 \\
\$ 340,797\end{array}$ & $\begin{array}{l}\$ 223951 \\
\$ 010243 \\
\$ \$ 2855\end{array}$ & $\begin{array}{l}\$ 40,501 \\
5223,051 \\
\$ 270,033 \\
\end{array}$ & $\begin{array}{l}\$ 400,440 \\
\$ 223,951 \\
\$ 225802 \\
\$ \$ 1.3051\end{array}$ & $\begin{array}{l}\$ 338,262 \\
\$ 223,051 \\
\$ 177,148 \\
\$ 02,837\end{array}$ & $\begin{array}{l}\$ 285,970 \\
\$ 223 \$ 51 \\
\$ 123,020 \\
\$ \$ 81010)\end{array}$ & $\begin{array}{l}101,500 \\
223,051 \\
504,750 \\
5597,200\end{array}$ \\
\hline $\begin{array}{l}=\text { Taxable Income } \\
\text { NET CASHFLOW }\end{array}$ & $\$ 292,090$ & $\$ 258,444$ & 4,977 & 1819 & 110 & 009 & $\$ 95,693$ & $\$ 65,360$ & $\$ 36231$ & $\$ 8,555$ & 93) & 5) & 8372 & 10) & (.200) \\
\hline Taxabb & & & & & & & & & & & & & & & \\
\hline $\begin{array}{l}\text { - Stab and Local Taves } \\
\text { - Foderal Taxes }\end{array}$ & $\begin{array}{l}\$ 28,289 \\
\$ 09,313\end{array}$ & $\begin{array}{l}\$ 23,260 \\
\$ 87,871\end{array}$ & $\begin{array}{l}\$ 20248 \\
\$ 78,492\end{array}$ & $\begin{array}{l}\$ 17264 \\
\$ 65218\end{array}$ & $\begin{array}{l}\$ 14,320 \\
\$ 54,096\end{array}$ & $\$ 43,183$ & $\begin{array}{r}\$ 8,612 \\
\$ 32,536\end{array}$ & $\begin{array}{r}\$ 5,882 \\
\$ 22222\end{array}$ & $\begin{array}{r}\$ 3281 \\
\$ 12,319\end{array}$ & $\begin{array}{r}\$ 770 \\
\$ 2.909\end{array}$ & $\begin{array}{l}\infty 0 \\
\infty 0\end{array}$ & $\$$ & $\begin{array}{l}\$ 0 \\
\text { so }\end{array}$ & $\$ 0$ & \\
\hline + Tax Credil & & & & & & & & & & & & & & & \\
\hline $\begin{array}{l}=\text { Net Income atter Taxes } \\
+ \text { Depredation }\end{array}$ & $\$ 186,495$ & $\begin{array}{l}\$ 147,313 \\
\$ 203951\end{array}$ & $\begin{array}{l}\$ 128237 \\
\$ 223951\end{array}$ & $\$ 109,337$ & $\begin{array}{l}\$ 00,393 \\
\$ 223,951\end{array}$ & $\begin{array}{r}\$ 72,395 \\
\$ 203051\end{array}$ & $\begin{array}{r}\$ 54,545 \\
\$ 230.54\end{array}$ & $\begin{array}{r}\$ 37255 \\
\$ 223951\end{array}$ & $\begin{array}{r}\$ 20,652 \\
\$ 223,951\end{array}$ & $\begin{array}{r}\$ 4,876 \\
\$ 223951\end{array}$ & 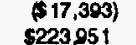 & $\begin{array}{l}\$ 41,305) \\
\$ 223051\end{array}$ & $\begin{array}{l}(562.837) \\
\$ 223.951\end{array}$ & $\begin{array}{l}\$ 81,610) \\
\$ 223.951\end{array}$ & $\begin{array}{l}5507.2001 \\
\$ 223251\end{array}$ \\
\hline $\begin{array}{l}\text { + Depredallon } \\
\text { - Principal paid on loan }\end{array}$ & $\$ 170.529$ & $\$ \$ \$ 187,581$ & $\$ 2003340$ & $\$ 226.974$ & 871 & $\$ 274,638$ & $\$ 302,102$ & $\$ 332,312$ & $\$ 365,543$ & $\$ 402,097$ & $\$ 442,307$ & $\$ 486,538$ & $\$ 535,192$ & & $\$ 647562$ \\
\hline$=$ CashFlo & $\$ 219,217$ & $\$ 183,683$ & $\$ 145,849$ & $\$ 100,214$ & & & $(\$ 23,606)$ & $(\$ 71,108)$ & $(\$ 120,240)$ & (\$173.270) & $(5235,749)$ & 891) & (\$374,078) & & \\
\hline $\begin{array}{l}\text { - Equily } \\
\text { = NETCASHFLC }\end{array}$ & $\begin{array}{r}\$ 54,979 \\
\$ 164,938\end{array}$ & $\begin{array}{r}\$ 45,921 \\
\$ 137.762\end{array}$ & $\begin{array}{r}\$ 30,462 \\
\$ 100,366\end{array}$ & $\begin{array}{l}\$ 28,579 \\
\$ 79,738\end{array}$ & $\begin{array}{l}\$ 16,243 \\
\$ 48,730\end{array}$ & $\begin{array}{r}\$ 5.427 \\
\$ 16281\end{array}$ & $\begin{array}{r}50 \\
(223,008)\end{array}$ & $\begin{array}{r}50 \\
(\$ 7 t, 100)\end{array}$ & $\begin{array}{r}50 \\
5+20,940)\end{array}$ & $\begin{array}{r}\$ 0 \\
\$ 173.270)\end{array}$ & $\begin{array}{r}50 \\
5235,740)\end{array}$ & $\begin{array}{r}80 \\
(5309.801)\end{array}$ & $\begin{array}{r}50 \\
(3974,078) \\
\end{array}$ & $\begin{array}{r}50 \\
5440,370)\end{array}$ & $\$ 520,831$ \\
\hline CUMORTIVE & & & & & & & & & & & & & & & \\
\hline & $\$ 5.254$ & $\$ 5,302$ & $\$ 5,501$ & $\$ 5,581$ & 3.030 & 3,046 & 8.022 & 5.551 & 55,430 & 85.257 & $\$ 5.021$ & 4.717 & 4,349 & 30907 & 3,370 \\
\hline $\begin{array}{l}\text { NET PFOFT IKK WH } \\
\text { (rot hoome/kw sold) }\end{array}$ & s0.011 & $\$ 0,010$ & $\$ 0.000$ & $\$ 0.007$ & $\$ 0,006$ & 50005 & 50004 & $\$ 0.002$ & $\$ 0.001$ & 80.000 & $\$ 0.001)$ & $\$ 0.003)$ & $\$ 0.004)$ & $(0.005)$ & $\$ 0.000$ \\
\hline
\end{tabular}




\begin{tabular}{|c|c|c|c|c|c|c|c|c|c|c|c|c|c|c|c|}
\hline 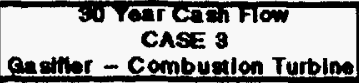 & $\begin{array}{c}\text { YEAR 1 } \\
1005 \\
\end{array}$ & $\begin{array}{r}2 \\
1000 \\
\end{array}$ & $\begin{array}{r}3 \\
1007 \\
\end{array}$ & $1000^{4}$ & $\begin{array}{r}5 \\
1000 \\
\end{array}$ & $\begin{array}{r}6 \\
2000 \\
\end{array}$ & $\begin{array}{r}7 \\
2001 \\
\end{array}$ & $\begin{array}{r}8 \\
2002 \\
\end{array}$ & $\begin{array}{r}9 \\
2003^{2} \\
\end{array}$ & $\begin{array}{r}10 \\
2004 \\
\end{array}$ & $\begin{array}{r}11 \\
2005 \\
\end{array}$ & $\begin{array}{r}12 \\
2000 \\
\end{array}$ & $\begin{array}{r}13 \\
2007 \\
\end{array}$ & $\begin{array}{r}14 \\
2006\end{array}$ & $\begin{array}{r}15 \\
2000 \\
\end{array}$ \\
\hline NETC & 3 & 3 & 3 & 3 & 3 & 3 & 3 & 3 & 3 & 3 & 3 & 3 & 3 & 3 & \\
\hline & 2 & & 2 & & 2 & 2 & 2 & 2 & 2 & 2 & 2 & 2 & 2 & 2 & \\
\hline $\begin{array}{l}\text { OPERATINGHO } \\
\text { ENERGY PROD }\end{array}$ & $\begin{array}{r}7500 \\
15000\end{array}$ & $\begin{array}{r}7500 \\
75000\end{array}$ & $\begin{array}{r}7500 \\
15000\end{array}$ & $\begin{array}{r}7500 \\
15000\end{array}$ & $\begin{array}{r}7500 \\
15000\end{array}$ & $750 \overline{0}$ & 7500 & 7500 & 7500 & 7500 & 7500 & 7500 & 7500 & 7500 & 7500 \\
\hline $\begin{array}{l}\text { ENERGY PRODLCED, MWHN } \\
\text { TPPFINGFEES }\end{array}$ & $\begin{array}{r}15000 \\
\$ 815,550\end{array}$ & $\begin{array}{r}15000 \\
-\$ 15850\end{array}$ & $\begin{aligned} 15000 \\
3015.550\end{aligned}$ & $\frac{15000}{6815 B 50}$ & $\begin{aligned} & 15000 \\
& 815,850\end{aligned}$ & $\frac{15000}{5615 \times 50}$ & $\frac{15000}{8815,850}$ & $\begin{array}{r}15000 \\
\$ 815,050\end{array}$ & $\frac{15000}{5015,850}$ & $\begin{aligned} 15000 \\
515,250\end{aligned}$ & $\begin{aligned} 15000 \\
5815,550\end{aligned}$ & $\frac{15000}{\$ 15 \$ 50}$ & $\frac{15000}{5015,050}$ & $\begin{array}{r}15000 \\
\$ 85050\end{array}$ & 50150000 \\
\hline UTITY SNLES \$YY & $\$ 1225,500$ & $\$ 1225,500$ & $\$ 1,225,500$ & $\$ 1,225,500$ & $\$ 1,225,500$ & $\$ 1225,500$ & $\$ 1225,500$ & $\$ 1225,500$ & $\$ 1225.500$ & $\$ 1225.500$ & $\$ 1,225,500$ & $\$ 1225,500$ & $\$ 1225,500$ & $\$ 1225,500$ & $\$ 1225,500$ \\
\hline $\begin{array}{l}\text { PETALL POWER OFFSET \$N } \\
\text { GROSS PEVENUE }\end{array}$ & $\begin{array}{r}\$ 735,000 \\
\$ 2776,350\end{array}$ & $\$ 735000$ & $\$ 735000$ & $\begin{array}{r}\$ 735,000 \\
\end{array}$ & $\begin{array}{r}8735000 \\
0770\end{array}$ & $\$ 735,000$ & $\$ 735,000$ & $\begin{array}{r}\$ 735000 \\
52778350\end{array}$ & 8735,000 & $\begin{array}{l}8735,000 \\
0770,350\end{array}$ & $\begin{array}{l}\$ 735,000 \\
2770,350\end{array}$ & 87 & $\$ 735,000$ & $\$ 735000$ & $\$ 735000$ \\
\hline ANNUAL LOAN PAYMENT & $\$ 441,651$ & $\$ 4441,051$ & $\frac{1010,000}{5441,051}$ & $\$ \frac{170,000}{\$ 41,651}$ & $\$ 441.051$ & $\frac{\alpha, 101,000}{\$ 441851}$ & $\$ 441,651$ & $\frac{\$ 21,01,001}{\$ 41,651}$ & $\frac{5441851}{\$ 41051}$ & $\$ 441,051$ & $\frac{\$ 2100,001}{\$ 441,651}$ & $\$ 441051$ & $\frac{8.101009}{\$ 441051}$ & $\frac{8,10,300}{\$ 441851}$ & $\frac{82,170,350}{\$ 441,051}$ \\
\hline $\begin{array}{l}\text { LOAN BALANCE } \\
\text { INTEFE ST PAYMENT }\end{array}$ & $\begin{array}{r}\$ 4,163,405 \\
\$ 416,341\end{array}$ & $\begin{array}{r}\$ 4,130,095 \\
\$ 4138,810\end{array}$ & $\begin{array}{r}\$ 4,110,254 \\
\$ 411025\end{array}$ & $\begin{array}{r}\$ 4079.628 \\
\$ 407.063\end{array}$ & $\begin{array}{l}\$ 4045,940 \\
\$ 404594\end{array}$ & $\begin{array}{r}44,008,883 \\
\$ 400888\end{array}$ & $\begin{array}{r}\$ 3,988,120 \\
\$ 396812\end{array}$ & $\begin{array}{l}\$ 3923,282 \\
\$ 392,328\end{array}$ & $\begin{array}{l}\$ 3873,950 \\
\$ 387,300\end{array}$ & $\begin{array}{r}\$ 3 \beta 19,704 \\
\$ 381970\end{array}$ & $\begin{array}{r}\$ 3,760,023 \\
\$ 376,002\end{array}$ & $\begin{array}{l}\$ 3094,375 \\
\$ 300,437\end{array}$ & $\begin{array}{l}\$ 3,622,161 \\
\$ 362216\end{array}$ & $\begin{array}{l}\$ 3,542,726 \\
\$ 354273\end{array}$ & $\begin{array}{l}\$ 3,455,348 \\
\mathbf{3 3 4 5 , 5 3 5}\end{array}$ \\
\hline PAINCIPAL PAYMENT & $\$ 25,310$ & $\$ 27 B 41$ & $\$ 30,626$ & $\$ 33,688$ & $\$ 37057$ & $\$ 40,763$ & $\$ 44839$ & $\$ 49,323$ & $\$ 54255$ & $\$ 50,581$ & $\$ 65,640$ & $\$ 72213$ & & & $\$ 08,110$ \\
\hline FUEL PUACHASE & & & & & & & & & & & & & & & \\
\hline 08 & $\$ 880,057$ & 5916,346 & 43,037 & $\$ 972,152$ & 01,317 & 031,350 & 062,207 & $1,004,100$ & 8,001 & 160,800 & 5.024 & .403 & 433 & 491 & 800 \\
\hline 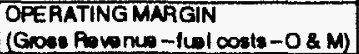 & 806,003 & 0.004 & .513 & 4.108 & 775,033 & 744,204 & 714,053 & 82,184 & 049.350 & 550 &, 720 & 57 & 12 & & 064 \\
\hline TAKABLE INCOME & & & & & & & & & & & & & & & \\
\hline $\begin{array}{l}\text { Operating Margin } \\
\text { - depredation } \\
\text { - Interus on obt } \\
\text { = Tavable inconte }\end{array}$ & $\begin{array}{r}\$ 1005,003 \\
\$ 125215 \\
\$ 410,341 \\
\$ 1,345,138\end{array}$ & $\begin{array}{r}\$ 1000,004 \\
\$ 223,051 \\
\$ 413810 \\
\$ 1222,243 \\
\end{array}$ & $\begin{array}{r}\$ 1032,513 \\
\$ 223,551 \\
\$ 411,025 \\
81,107,537\end{array}$ & $\begin{array}{r}\$ 1,004,108 \\
\$ 223,951 \\
\$ 407,003 \\
\$ 1,172,284\end{array}$ & $\begin{array}{r}\$ 1,775,033 \\
\$ 223,051 \\
\$ 404,504 \\
\$ 1,146,488\end{array}$ & $\begin{array}{r}\$ 1,744,904 \\
\$ 223,051 \\
\$ 400,060 \\
\$ 1,120,154\end{array}$ & $\begin{array}{r}\$ 1.714 .063 \\
\$ 223,951 \\
\$ 300 \Delta 12 \\
\$ 1,093,200\end{array}$ & $\begin{array}{r}\$ 1,662,184 \\
\$ 223,251 \\
\$ 392,320 \\
\$ 1.065,005\end{array}$ & $\begin{array}{r}\$ 1049.350 \\
\$ 223.951 \\
\$ 357,300 \\
\$ 1030,012\end{array}$ & $\begin{array}{r}\$ 1,1515,650 \\
\$ 223,051 \\
\$ 301,970 \\
\$ 1,000,028\end{array}$ & $\begin{array}{r}\$ 1.500,720 \\
\$ 203,251 \\
\$ 370,002 \\
\$ 080,772\end{array}$ & $\begin{array}{r}\$ 1,544,057 \\
8223,051 \\
8360,437 \\
5951,408\end{array}$ & $\begin{array}{r}\$ 1,507.912 \\
\$ 223,951 \\
\$ 302210 \\
\$ 021,745\end{array}$ & $\begin{array}{r}\$ 1.400,050 \\
\$ 223.056 \\
\$ 354273 \\
\$ 091035\end{array}$ & $\begin{array}{r}\$ 1,430,004 \\
8223.051 \\
6325, .535 \\
5001,178\end{array}$ \\
\hline NETCASHFLOW & & & & & & & & & & & & & & & \\
\hline $\begin{array}{l}\text { Taxabl Income } \\
\text { - Stat and Local Taves }\end{array}$ & & & & & & & & & & & & & & & $\begin{array}{r}\$ 77,500 \\
\$ 202,801\end{array}$ \\
\hline $\begin{array}{l}\text { - Foderal Taxos } \\
\text { + Tax Codit } \\
\text { = Net Incone aher Taxes }\end{array}$ & $\begin{array}{l}\$ 457,347 \\
\$ 0 \\
\$ 706,728\end{array}$ & $\begin{array}{r}\$ 415,503 \\
\$ 0 \\
\$ 606,878\end{array}$ & $\begin{array}{l}\$ 407,102 \\
\$ 0 \\
\$ 682596\end{array}$ & $\begin{array}{r}\$ 308,577 \\
\$ 0 \\
\$ 068202\end{array}$ & $\begin{array}{r}\$ 380,800 \\
\$ 0 \\
\$ 653,498\end{array}$ & $\begin{aligned} \$ 380,053 \\
\$ 0 \\
\$ 638,488\end{aligned}$ & $\begin{array}{l}\$ 371,718 \\
\$ 0 \\
\$ 623,175\end{array}$ & $\begin{array}{r}\$ 362,408 \\
60 \\
\$ 607566\end{array}$ & $\begin{array}{r}\$ 352,024 \\
\$ 0 \\
\$ 501067\end{array}$ & $\begin{array}{r}\$ 343,274 \\
\$ 0 \\
\$ 575,488\end{array}$ & $\begin{array}{r}\$ 333,463 \\
\$ 0 \\
\$ 559,040\end{array}$ & $\begin{aligned} \$ 323,499 \\
50 \\
\$ 542,337\end{aligned}$ & $\begin{array}{r}\$ 313,303 \\
50 \\
\$ 525,305\end{array}$ & $\begin{array}{r}\$ 303,150 \\
\$ 0 \\
\$ 508,232\end{array}$ & $\begin{array}{r}\$ 292 B 01 \\
\$ 0 \\
\$ 490,872\end{array}$ \\
\hline + Depreciation & $\$ 201,960$ & $\$ 223,951$ & $\$ 223.951$ & $\$ 223,251$ & $\$ 223.851$ & 5223,951 & $\$ 223,951$ & $\$ 223,051$ & $\$ 223,051$ & $\$ 223,051$ & $\$ 223.251$ & $\$ 223251$ & 951 & 5223.251 & \\
\hline - Principal paid on loan & $\$ 25,310$ & $\$ 25,310$ & $\$ 30.826$ & $\$ 33688$ & $\$ 37,057$ & $\$ 40,763$ & & & $\$ 54,255$ & $\$ 50,001$ & $\$ 65,649$ & & & & \\
\hline - Cashflow & $\$ 943.378$ & $\$ 895,310$ & $\$ 875,922$ & $\$ 858,465$ & $\$ 840,393$ & $\$ 821.677$ & 8802288 & $\$ 782,194$ & $\$ 701,363$ & $\$ 730.750$ & $\$ 717,343$ & 075 & $\$ 060,011$ & & 07 \\
\hline $\begin{array}{l}\text { - Equity } \\
\text { = NETCASH FLOW }\end{array}$ & & & & & & & & & & & & $\$ 173,510$ & & & $\$ 154.077$ \\
\hline CUMULATI & & & & & & & & & & & & & & & \\
\hline & 8708 & $\$ 1,379$ & $\$ 2.030$ & $\$ 2,000$ & $\$ 3,310$ & 53,020 & $\$ 4,528$ & $\$ 5,115$ & $\$ 5.000$ & 1241 & 0,778 & 7200 & 7802 & 0285 & 0.740 \\
\hline RET PFOFIT BKWWH & 051 & 040 & 2040 & 1045 & 094 & 043 & 50042 & 0041 & 50039 & $\$ 0.038$ & 50.037 & 50.036 & 50.035 & 00034 & $\$ 0.033$ \\
\hline
\end{tabular}




\begin{tabular}{|c|c|c|c|c|c|c|c|c|c|c|c|c|c|c|c|}
\hline 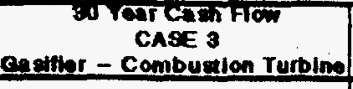 & $\begin{array}{r}\text { YEAA } 16 \\
2010 \\
\end{array}$ & $\begin{array}{r}17 \\
2011 \\
\end{array}$ & $\begin{array}{r}18 \\
2012 \\
\end{array}$ & $\begin{array}{r}19 \\
2013 \\
\end{array}$ & $\begin{array}{r}20 \\
2014 \\
\end{array}$ & $\begin{array}{r}21 \\
2015 \\
\end{array}$ & $\begin{array}{r}22 \\
2010 \\
\end{array}$ & $\begin{array}{r}23 \\
2017 \\
\end{array}$ & $\begin{array}{r}24 \\
2010 \\
\end{array}$ & $\begin{array}{r}25 \\
2010 \\
\end{array}$ & $\begin{array}{r}26 \\
2020 \\
\end{array}$ & $\begin{array}{r}27 \\
2021 \\
\end{array}$ & $\begin{array}{r}28 \\
2022 \\
\end{array}$ & $\begin{array}{r}29 \\
2023 \\
\end{array}$ & $\begin{array}{r}30 \\
2024 \\
\end{array}$ \\
\hline TCAPACITY OUTPUT, MW & 3 & 3 & 3 & 3 & 3 & 3 & 3 & 3 & $\mathbf{3}$ & 3 & 3 & 3 & 3 & 3 & \\
\hline TNG & & & 2 & & 2 & 2 & & 2 & 2 & 2 & 2 & 2 & 2 & 2 & \\
\hline $\begin{array}{l}\text { OFERATING HOUF } \\
\text { ENERGY PROOUC }\end{array}$ & $\begin{array}{r}7500 \\
15000\end{array}$ & 7500 & 7500 & 7500 & 7500 & 7500 & 7500 & 7500 & 7500 & 7500 & 7500 & 7500 & 7500 & 7500 & 7500 \\
\hline $\begin{array}{l}\text { ENERGY PROOUCED, MWH } \\
\text { TPPINGTEES }\end{array}$ & $\begin{aligned} 15000 \\
815,850\end{aligned}$ & $\begin{array}{r}15000 \\
\$ 85050\end{array}$ & $\begin{array}{r}15000 \\
\$ 015850\end{array}$ & $\begin{array}{r}15000 \\
3815050\end{array}$ & $\begin{array}{r}15000 \\
3015050\end{array}$ & $\begin{array}{r}15000 \\
8815850\end{array}$ & $\begin{array}{r}15000 \\
15050\end{array}$ & $\begin{array}{r}15000 \\
80.15050\end{array}$ & $\frac{15000}{3015.50}$ & $\begin{array}{r}15000 \\
3515050\end{array}$ & $\frac{15000}{5015050}$ & $\begin{aligned} 15000 \\
0.5060\end{aligned}$ & 15000 & 15000 & $\begin{array}{r}15000 \\
5150\end{array}$ \\
\hline UTLTY SNLES, GN & $\$ 1225,500$ & $\$ 1,225,500$ & $\$ 1225,500$ & $\$ 1,225,500$ & 1225,500 & $\$ 1225,500$ & $\$ 1225,500$ & $\$ 1225,500$ & $\$ 1225.500$ & $\$ 1225.500$ & 1225.500 & & & $\begin{array}{r}2015,550 \\
51225.500\end{array}$ & $\begin{array}{r}\$ 1225,500 \\
\$ 125,500\end{array}$ \\
\hline SET $\$ Y$ & $\$ 735,000$ & $\$ 735,000$ & $\$ 735,000$ & $\$ 735,000$ & $\$ 735,000$ & $\$ 735,000$ & $\$ 735000$ & $\$ 735,000$ & $\$ 735000$ & 8735,000 & 000 & $\$ 73$ & 000 & $\$ 735,000$ & $\$ 735000$ \\
\hline GPOSS FEVENI & $\$ 2,776,350$ & $\$ 2,776,350$ & $\$ 2,776,350$ & $\$ 2,770,350$ & $\$ 2,776,350$ & $\$ 2,770,350$ & 350 & $\$ 2,776,350$ & $\$ 2,770,350$ & $\$ 2,770,350$ & $\$ 2,77$ & 82.77 & 350 & & $2,770.350$ \\
\hline ANNUAL LOAN & $\$ 441,651$ & $\$ 441,051$ & $\$ 441851$ & $\$ 441,651$ & $\$ 441,651$ & $\$ 441.651$ & $\$ 441851$ & $\$ 441051$ & $\$ 441051$ & $\$ 441,051$ & $\$ 441051$ & $\$ 441051$ & $\$ 441051$ & 8441051 & 541051 \\
\hline $\begin{array}{l}\text { LOAN BALANCE } \\
\text { INTERE ST PAYYENT }\end{array}$ & $\$ 3,359,232$ & $\$ 3253,504$ & $\$ 3,137,204$ & $\$ 3,000,273$ & $\$ 2,868,550$ & $\$ 2,713,754$ & $\$ 2,543,478$ & $\$ 2,358,175$ & & $\$ 1,823,505$ & $\$ 1074,204$ & $\$ 1,300,974$ & $\$ 1000,320$ & & $\$ 401.501$ \\
\hline PPINKIP AL PAYMENT & $\$ 105,728$ & $\$ \$ \$ 116,300$ & $\$ 127,031$ & $\$ 140,724$ & $\$ 154,706$ & $\begin{array}{l}\$ 170276 \\
\$\end{array}$ & $\$ 187,303$ & $\$ 200,033$ & $\$ 226,1037$ & $\$ 249,300$ & $\$ 274230$ & $\$ 301,654$ & $\$ 331810$ & $\$ 365001$ & 401,501 \\
\hline $\begin{array}{l}\text { FUEL PUACHASE COSTS.BN } \\
\text { O\& M }\end{array}$ & $\begin{array}{r}\$ 0 \\
\$ 1,380,050\end{array}$ & $\begin{array}{r}\$ 0 \\
\$ 1.427 .038\end{array}$ & $\begin{array}{r}50 \\
\$ 1,470,467\end{array}$ & $\begin{array}{r}\$ 0 \\
\$ 1,514,581\end{array}$ & $\begin{array}{r}50 \\
360,018\end{array}$ & $\begin{array}{r}\$ 0 \\
\$ 00.810\end{array}$ & $\begin{array}{r}\$ 50 \\
\$ 55,024\end{array}$ & 704,074 & 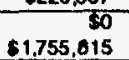 & $\$ 1,808,480$ & $\$ 1862.744$ & 1918,020 & $\begin{array}{r}50 \\
\$ 1,970,185\end{array}$ & $\begin{array}{r}50 \\
\$ 2,035,470\end{array}$ & 534 \\
\hline 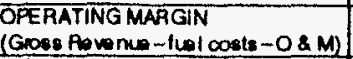 & $\$ 1,300,294$ & $\$ 1,348,712$ & 305,863 & 201.700 & 210.332 & 160.531 & 121,320 & 071,070 & 020,535 & 67.001 & 1000 & 57.724 & $\infty, 105$ & 880 & 1816 \\
\hline TAXABLE INCOME & & & & & $=-\infty$ & , & 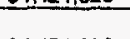 & 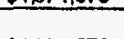 & 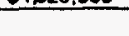 & ו & & & & & 1910 \\
\hline $\begin{array}{l}\text { Operating Margin } \\
\text { - depeciation } \\
\text { - Interest on debt } \\
\text { = Taxable income }\end{array}$ & $\begin{array}{r}\$ 1,300,294 \\
\$ 223,051 \\
\$ 335,023 \\
\$ 830,419\end{array}$ & $\begin{array}{r}\$ 1,340,712 \\
\$ 223,951 \\
\$ 325,350 \\
\$ 799,410\end{array}$ & $\begin{array}{l}\$ 1,305,003 \\
\$ 223,951 \\
\$ 313.720 \\
\$ 708,211\end{array}$ & $\begin{array}{l}\$ 1201.700 \\
\$ 223.851 \\
\$ 300,927 \\
\$ 736,090\end{array}$ & $\begin{array}{l}\$ 1,210,332 \\
\$ 223,951 \\
\$ 206,855 \\
\$ 705,525\end{array}$ & $\begin{array}{l}\$ 1,160,531 \\
\$ 223,051 \\
\$ 271,375 \\
\$ 674,204\end{array}$ & $\begin{array}{r}\$ 1,121,328 \\
\$ 223,051 \\
\$ 254,348 \\
\$ 643,027\end{array}$ & $\begin{array}{l}\$ 1,071,070 \\
\$ 223,951 \\
\$ 235,018 \\
\$ 612,107\end{array}$ & $\begin{array}{l}\$ 1020,535 \\
\$ 223,051 \\
\$ 215,014 \\
\$ 581,570\end{array}$ & $\begin{array}{l}\$ 007801 \\
\$ 223.251 \\
\$ 192,350 \\
\$ 551,559\end{array}$ & $\begin{array}{l}\$ 013,800 \\
\$ 223.251 \\
\$ 107,420 \\
\$ 522,235\end{array}$ & $\begin{array}{l}8057,724 \\
\$ 223 ., 251 \\
8139.907 \\
\$ 193775\end{array}$ & $\begin{array}{l}\$ 800,105 \\
\$ 223.051 \\
\$ 100,832 \\
\$ 100,389\end{array}$ & $\begin{array}{l}\$ 740,000 \\
\$ 223,051 \\
\$ 70,050\end{array}$ & $\begin{aligned} \$ 670.816 \\
\$ 223.051 \\
\$ 40.150 \\
\$ 415.714\end{aligned}$ \\
\hline NETCAS & & & & & & & & & $\$ 581,570$ & 559 & & 1.775 & 3,382 & 0.278 & 5.714 \\
\hline $\begin{array}{l}\text { Taxable Income } \\
\text { - Stab and Local Taxes }\end{array}$ & & & & & & & & & & & & & & & \\
\hline $\begin{array}{l}\text { - Foderal Taxes } \\
\text { + Tax Crodit } \\
\text { = Net Incone aner Taxes }\end{array}$ & $\begin{array}{r}\$ 282,343 \\
\$ 0 \\
\$ 473,339\end{array}$ & $\begin{array}{r}\$ 271,800 \\
\$ 0 \\
\$ 455,804\end{array}$ & $\begin{array}{r}\$ 281,102 \\
\$ 0 \\
\$ 437,880\end{array}$ & $\begin{aligned} \$ 250,543 \\
\$ 0 \\
\$ 420,028\end{aligned}$ & $\begin{array}{r}\$ 239,879 \\
\$ 0 \\
\$ 402,149\end{array}$ & $\begin{array}{r}\$ 229220 \\
\$ 0 \\
\$ 384,296\end{array}$ & $\begin{array}{r}\$ 218,629 \\
\$ 0 \\
\$ 366,528\end{array}$ & $\begin{aligned} \$ 208,+118 \\
\$ 0 \\
\$ 348,901\end{aligned}$ & $\begin{array}{r}\$ 107,734 \\
\$ 0 \\
\$ 331,495\end{array}$ & $\begin{array}{r}\$ 107,530 \\
\$ 0 \\
\$ 314,388\end{array}$ & $\begin{array}{l}\$ 177580 \\
\$ 0 \\
\$ 297674\end{array}$ & $\begin{array}{l}\$ 167804 \\
\$ 0 \\
\$ 281,452\end{array}$ & $\begin{array}{r}\$ 150 \$ 70 \\
\$ 0 \\
\$ 285838\end{array}$ & $\begin{array}{r}\$ 140,605 \\
\$ 0 \\
\$ 250,250\end{array}$ & $\begin{array}{l}\$ 14+, 343 \\
\$ 230,257\end{array}$ \\
\hline + Depreckation & $\$ 223.951$ & $\$ 223.051$ & $\$ 223,951$ & $\$ 223,951$ & & 3.051 & & & & & & & & & 2951 \\
\hline - Principal paid on loan & $\$ 105,728$ & $\$ 110,300$ & $\$ 127.031$ & $\$ 140,724$ & $\$ 154,796$ & $\$ 170276$ & $\$ 187,303$ & $\$ 200,033$ & $\$ 228,637$ & $\infty$ & $\$ 274,230$ & 554 & 819 & 01 & $\$ 01,501$ \\
\hline$=$ Cashflow & 5501,563 & $\$ 583,315$ & 201 & 3255 & $\$ 471,305$ & $\$ 437,072$ & $\$ 403,174$ & $\$ 368819$ & $\$ 328,800$ & & $\$ 247395$ & & & $\infty$ & $\$ 50,4$ \\
\hline - Equit & $\$ 147891$ & 829 & 475 & 114 & 1828 & 100403 & 702 & 70 & & & & & & & 014000 \\
\hline$=$ MET & 872 & $c^{2}+$ & 428 & & 478 & .478 & $\$ 302380$ & 5.114 & 807 & 780 & 5.546 & 012 & $\$ 11 B, 478$ & $\$ 82,432$ & $\$ 44550$ \\
\hline $\begin{array}{l}\text { CUMULATIVE CASHFLOW } \\
\text { (ahousands) }\end{array}$ & $\$ 9,193$ & $\$ 0,815$ & $\$ 10,010$ & $\$ 10,393$ & $\$ 10,747$ & 11075 & $\$ 11,378$ & 11053 & $\$ 11,000$ & $\$ 12.110$ & $\$ 12,302$ & $\$ 12,454$ & $\$ 12,573$ & $\$ 12055$ & $\$ 12,700$ \\
\hline $\begin{array}{l}\text { NET PAOFIT SKWH } \\
\text { (net inconre, KW sold) }\end{array}$ & 50032 & $\$ 0030$ & $\$ 0.029$ & $\$ 0.028$ & so.027 & so.026 & $\$ 0.024$ & 50.023 & 50.023 & $009 ?$ & 50.020 & 50218 & 0018 & 0017 & 50.0 io \\
\hline
\end{tabular}




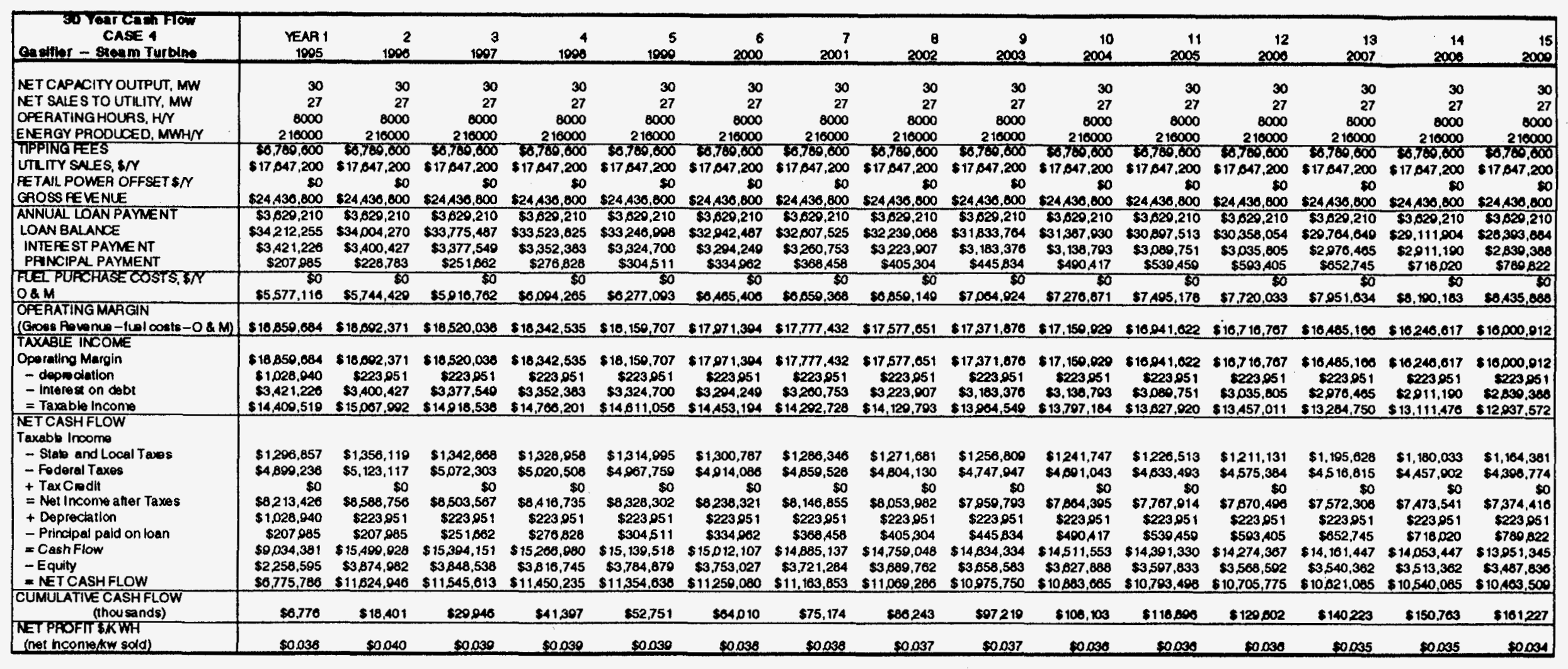




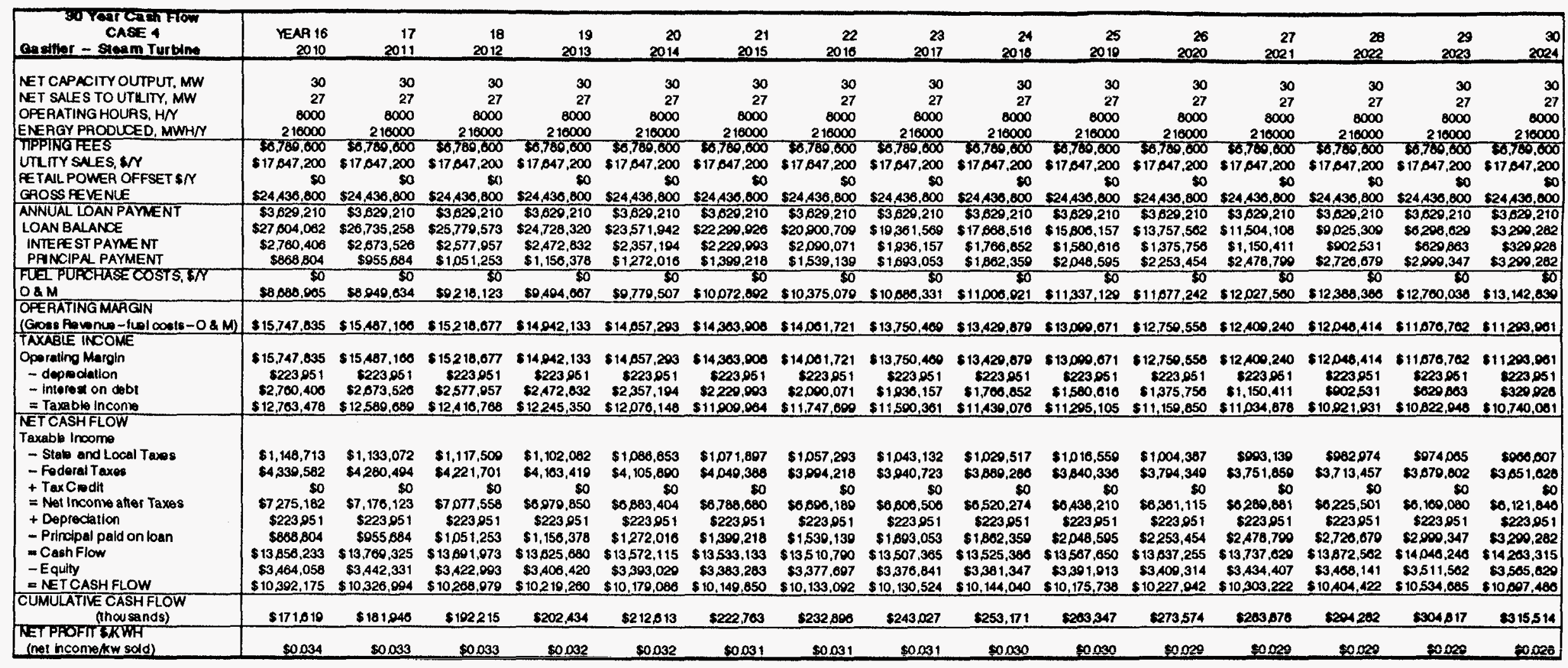




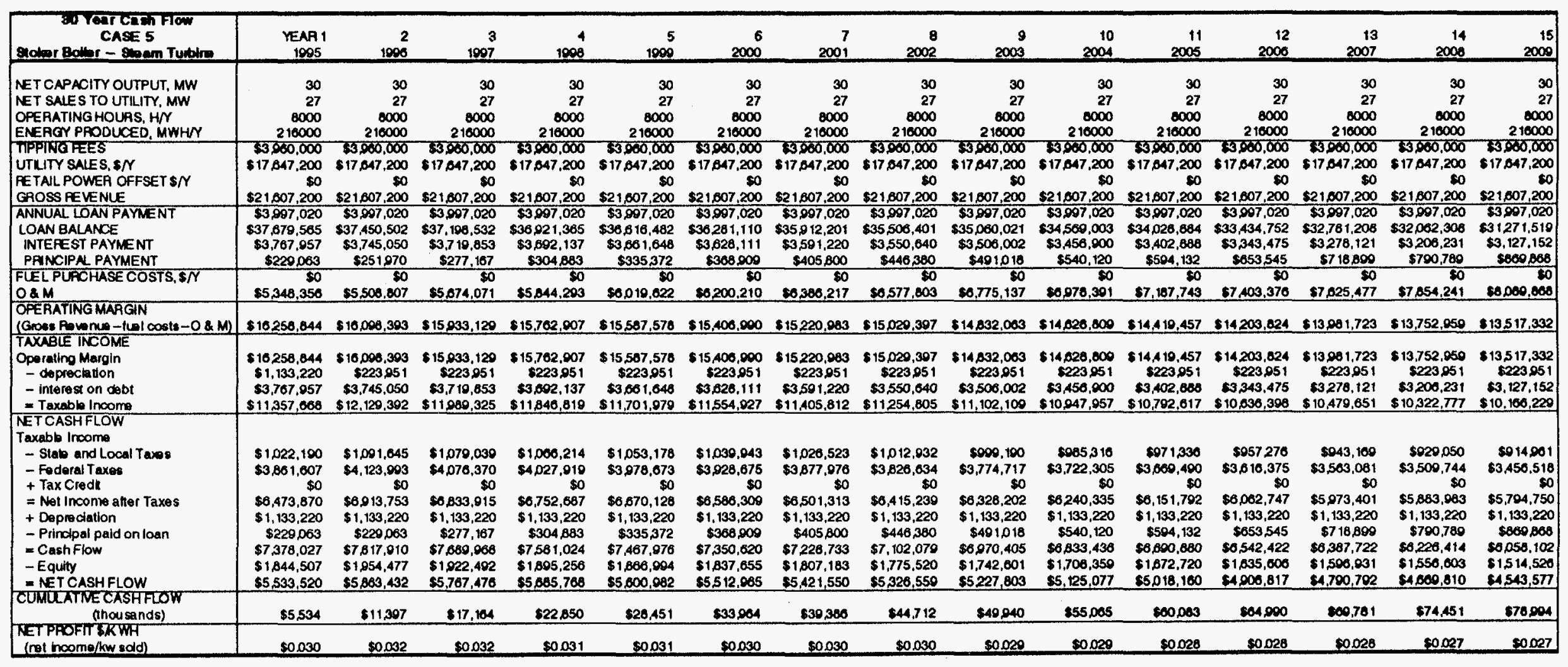




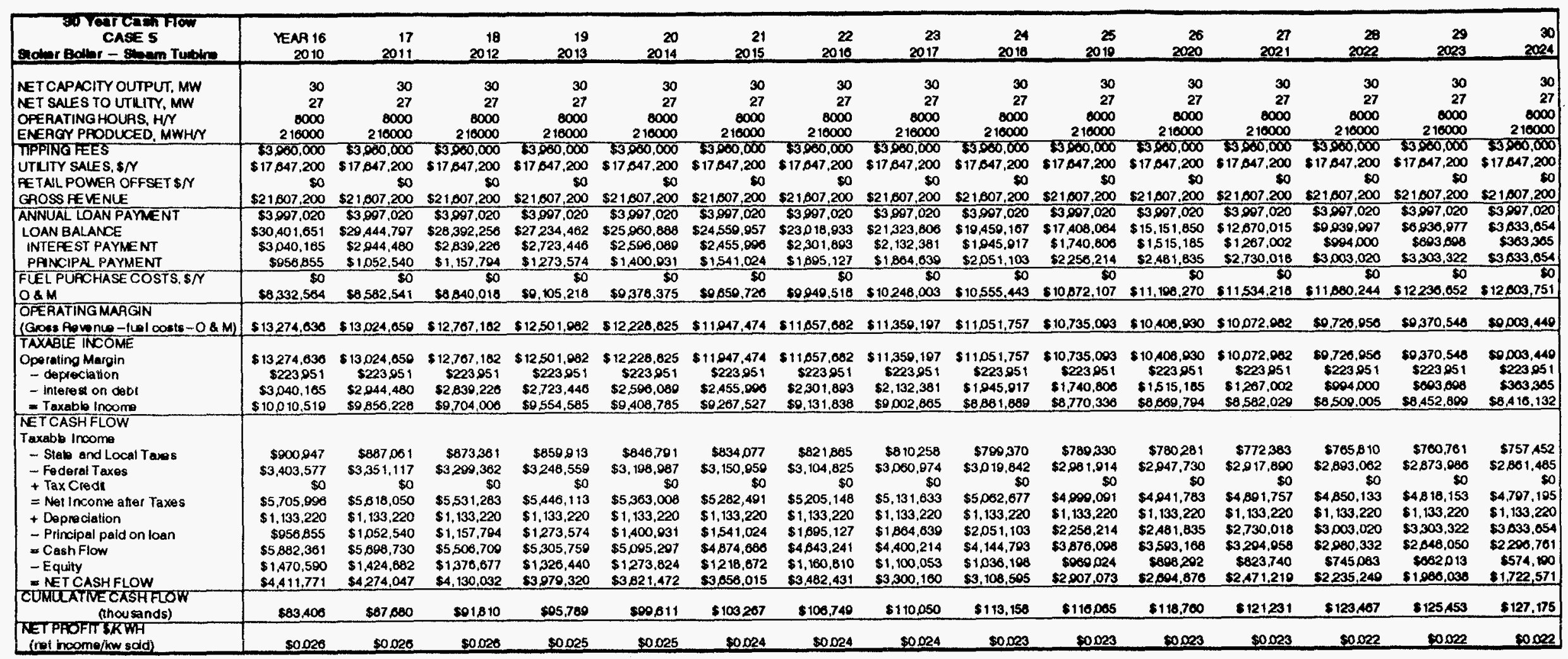




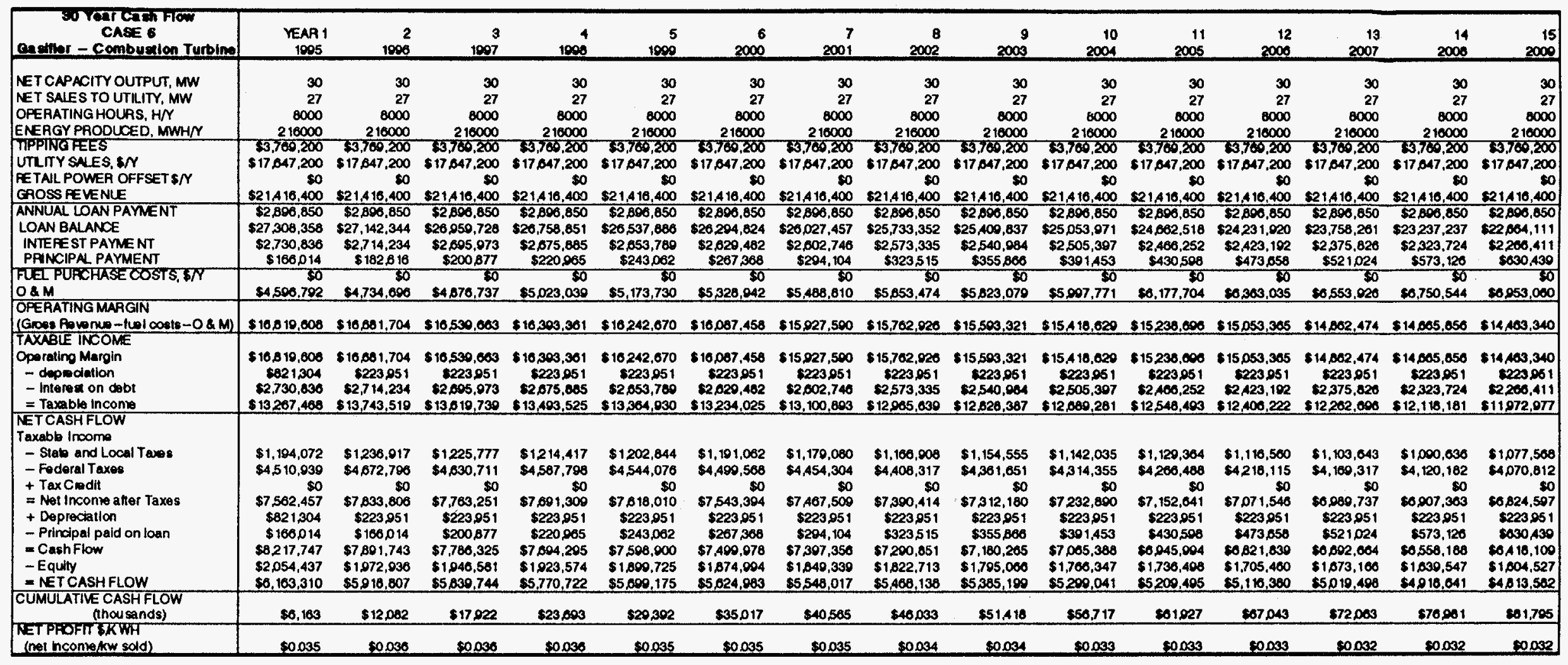




\begin{tabular}{|c|c|c|c|c|c|c|c|c|c|c|c|c|c|c|c|}
\hline 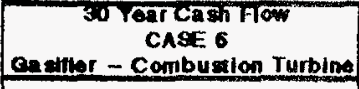 & $\begin{array}{r}\text { VEAP } 16 \\
2010 \\
\end{array}$ & $\begin{array}{r}17 \\
2011 \\
\end{array}$ & $\begin{array}{r}18 \\
2012 \\
\end{array}$ & $\begin{array}{r}19 \\
2013 \\
\end{array}$ & $\begin{array}{r}20 \\
2014 \\
\end{array}$ & $\begin{array}{r}21 \\
2015 \\
\end{array}$ & $\begin{array}{r}22 \\
2016 \\
\end{array}$ & $\begin{array}{r}23 \\
2017 \\
\end{array}$ & $\begin{array}{r}24 \\
2016 \\
\end{array}$ & $\begin{array}{r}25 \\
2010 \\
\end{array}$ & $\begin{array}{r}26 \\
2020 \\
\end{array}$ & $\begin{array}{r}27 \\
2021 \\
\end{array}$ & $\begin{array}{r}28 \\
2022 \\
\end{array}$ & $\begin{array}{r}29 \\
2023 \\
\end{array}$ & 2024 \\
\hline NE & & 30 & 30 & 30 & 30 & 30 & 30 & 30 & 30 & 30 & 30 & 30 & 10 & 30 & \\
\hline & & & 27 & 27 & 27 & 27 & 27 & 7 & 27 & 27 & 27 & 27 & 27 & 27 & \\
\hline AXWWX & 3000 & 1000 & 8000 & 8000 & 8000 & 8000 & 8000 & 8000 & 8000 & 8000 & 8000 & 8000 & 8000 & 8000 & $\infty$ \\
\hline $\begin{array}{l}\text { PRODUCED, AAWH } \\
\text { FEES }\end{array}$ & $\begin{array}{r}218000 \\
33760200\end{array}$ & $\begin{array}{r}216000 \\
30000\end{array}$ & 210000 & $\frac{216000}{780000}$ & 210000 & 210000 & 216000 & 216000 & 218000 & 210000 & 210000 & & & & \\
\hline HES & 047,200 & $17,0007,200$ & $\begin{array}{r}\$ 3,760,200 \\
\$ 17 \$ 47,200\end{array}$ & $\begin{array}{r}83,700,200 \\
\$ 17047,200\end{array}$ & 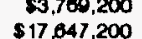 & $\begin{array}{r}\$ 3,700,200 \\
517047,200\end{array}$ & $\begin{array}{r}\$ 3.700 .200 \\
517047,200\end{array}$ & $\begin{array}{r}\$ 3,760,200 \\
517047,200\end{array}$ & $\begin{array}{l}3,760,200 \\
7.947,200\end{array}$ & $0.760,200$ & $03,700,200$ & $\$, 700,200$ & $\infty$ & $3,760,200$ & 37 \\
\hline FE & & & & & & & & & & & & $\begin{array}{l}200 \\
\$ 0\end{array}$ & & 200 & \\
\hline GAC & $\$ 21,4$ & $\$ 21$. & 1,400 & 8,400 & 3.400 & 10,400 & 3.400 & 0.400 & $\$ 21,416,400$ & 16,400 & 0.400 & 0.400 & 100 & $\$ 21$ & \\
\hline$\overline{\text { ANN }}$ & $\$ 2,896,850$ & $\$ 2,896,850$ & $\$ 2,896,850$ & $\$ 2,896,850$ & 8,850 & 18.850 & 850 & 8,850 & $\$ 2,806,850$ & $\frac{10,400}{8,850}$ & .050 & & & & \\
\hline$L$ & 3,672 & $\$ 21,340,189$ & $\$ 20,577,358$ & $\$ 19,738,244$ & $\$ 18$ & 9,800 & & & $\$ 14,103,070$ & 537 & 341 & & & & \\
\hline & $\$ 2,20$ & $\$ 2,134,019$ & $\$ 2,057,736$ & $\$ 1,973,824$ & 622 & & & & & & & & & & \\
\hline & $\$ 693,483$ & $\$ 762,831$ & $\$ 839,114$ & $\$ 823.028$ & & & & & 542 & & & & & 091 & $\$ 2033,500$ \\
\hline $\begin{array}{l}\text { FUE PUFCHASE COSTS, W } \\
\text { O\& M }\end{array}$ & $\$ 7,101,852$ & $\$ \begin{array}{r}\$ 0 \\
\$ 7,370,502\end{array}$ & $\begin{array}{r}\$ 0 \\
\$ 7,597,797\end{array}$ & $\begin{array}{r}\$ 0 \\
\$ 7825.731\end{array}$ & 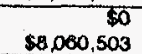 & $\begin{array}{l}50 \\
518\end{array}$ & $\begin{array}{r}50 \\
\$ 8,551,387\end{array}$ & $\begin{array}{l}50 \\
.929\end{array}$ & $\begin{array}{l}50 \\
.167\end{array}$ & $\begin{array}{l}50 \\
.332\end{array}$ & $\begin{array}{r}50 \\
4.062\end{array}$ & $\begin{array}{l}80 \\
13.401\end{array}$ & $\begin{array}{l}50 \\
0.804\end{array}$ & $\begin{array}{r}80 \\
17.128\end{array}$ & $\begin{array}{l}100 \\
041\end{array}$ \\
\hline TING GAQGIN & & & & & & & & & & & & & & & \\
\hline & & & & & & & & & & & & & & & \\
\hline $\begin{array}{l}\text { Operating Margin } \\
\text { - deprecialion } \\
\text { - interes on dabt }\end{array}$ & $\begin{array}{r}\$ 14254.748 \\
\$ 223.851 \\
\$ 2.203 .307\end{array}$ & $\begin{array}{r}\$ 14,230,008 \\
\$ 223,051 \\
\$ 2,134,010\end{array}$ & $\begin{array}{r}\$ 13,818,003 \\
\$ 223,951 \\
\$ 2,057,730\end{array}$ & $\begin{array}{r}13,500,660 \\
\$ 223,951 \\
\$ 1,073,824\end{array}$ & $\begin{array}{r}\$ 13,355,097 \\
\$ 223,051 \\
\$ 1,001,522\end{array}$ & $\begin{array}{r}\$ 13,114,082 \\
\$ 223,051 \\
\$ 1,770,000\end{array}$ & $\begin{array}{r}\$ 12,065,013 \\
\$ 223,051 \\
\$ 1006,303\end{array}$ & $\begin{array}{r}\$ 12,000,471 \\
\$ 223,051 \\
\$ 1,545,448\end{array}$ & $\begin{array}{r}\$ 12,344,233 \\
\$ 223,951 \\
\$ 1,410,306\end{array}$ & $\begin{array}{r}\$ 12,072,008 \\
\$ 223,951 \\
\$ 1,261,054\end{array}$ & $\begin{array}{r}\$ 11,701.738 \\
\$ 223,951 \\
\$ 1090.134\end{array}$ & $\begin{array}{r}\$ 11.502 .000 \\
\$ 223.251 \\
\$ 016.202\end{array}$ & $\begin{array}{r}\$ 11205,500 \\
\$ 223,051 \\
\$ 720,404\end{array}$ & $\begin{array}{r}\$ 10.800 .272 \\
\$ 223.951 \\
\$ 502.750\end{array}$ & $\begin{array}{r}10,503,750 \\
5223,051 \\
\quad 203,350\end{array}$ \\
\hline $\begin{aligned}=\text { Taxab } \\
\text { NETCASF }\end{aligned}$ & $\$ 11,827.420$ & $\$ 11,001,028$ & $\$ 11,530.010$ & $\$ 11,302,894$ & $\$ 11250,424$ & $\$ 11,110,142$ & $\$ 10,972,750$ & $\$ 10839.072$ & $\$ 10,700,074$ & $\$ 10,560,463$ & $\$ 10,400,053$ & $\$ 10,360,785$ & $\$ 10201,242$ & $\$ 10.172 .502$ & $\$ 10,000,457$ \\
\hline & & & & & & & & & & & & & & & \\
\hline $\begin{array}{l}\text { Local Tases } \\
\text { Kas }\end{array}$ & 4.489 & & & $\begin{array}{l}360 \\
584\end{array}$ & 538 & 913 & & & & & & & & & \\
\hline $\begin{array}{l}+ \text { TaxC } \\
=\text { Net II }\end{array}$ & & & & & & & & & & & & & & & $\begin{array}{r}795 \\
\$ 0\end{array}$ \\
\hline atter Taxes & $\begin{array}{r}\$ 6,741,635 \\
\$ 223,851\end{array}$ & $\begin{array}{r}\$ 6,658,699 \\
\$ 223,951\end{array}$ & $\begin{array}{c}\$ 6.576,042 \\
\$ 223,95 ?\end{array}$ & & & & & $\$ 6,178,271$ & 685 & 334,224 & .702 & 5.647 & & 360 & 081 \\
\hline - Prina & & & $\begin{array}{l}\$ 223,951 \\
\$ 839.114\end{array}$ & 28 & $\begin{array}{l}51 \\
28\end{array}$ & 61 & $\$ 223.951$ & 1951 & 3.951 & 23,051 & $\$ 223,951$ & $\$ 223.951$ & 251 & $\$ 223.951$ & 951 \\
\hline & 3 & & & 5 & & & & & & & & $\begin{array}{l}\$ 1,978,588 \\
\$ 4,151,011\end{array}$ & $\begin{array}{l}440 \\
413\end{array}$ & $\begin{array}{l}\$ 2,304,001 \\
\$ 3,028,221\end{array}$ & $\begin{array}{r}52,033,500 \\
53,345,432\end{array}$ \\
\hline$-E$ & & & & 710 & & 008 & $\$ 1,312,460$ & $\$ 1262,705$ & $\$ 1210.524$ & $\$ 1,155,760$ & 234 & 753 & 103 & 055 & 50 \\
\hline$=N E$ & 704,077 & $\$ 4,580,864$ & $4,470,659$ & $\$ 4,346,156$ & $\$ 4218,024$ & $\$ 4,079,003$ & $\$ 3.037,407$ & $\$ 3.788,115$ & $\$ 3.031,571$ & $\$ 3.467 .279$ & $3,204,703$ & $\$ 3.113,258$ & $2,022,300$ & $\$ 2,721,105$ & $\$ 2,500,074$ \\
\hline $\begin{array}{l}\text { CUMULATIVE C } \\
\text { tho }\end{array}$ & $\$ 60,490$ & $\$ 91.089$ & 805.550 & 0,005 & $\$ 104,122$ & $\$ 108,201$ & $\$ 112.130$ & 115,927 & 110,559 & $\$ 123020$ & $\$ 120,320$ & 120,434 & 132,350 & 135.077 & 137,500 \\
\hline $\begin{array}{l}\text { NETPROFT \&KWW } \\
\text { (net hconie KW sold) }\end{array}$ & & 231 & 0 & 0.30 & 030 & 0,020 & 020 & 020 & 1020 & 020 & 028 & 0.027 & 0.027 & 0.027 & 0.027 \\
\hline
\end{tabular}

